\title{
SOBRE A TEORIA CONSTITUCIONAL BRASILEIRA E A CARTA CIDADÃ DE 1988: DO PÓS-POSITIVISMO AO NEOCONSTITUCIONALISMO / ABOUT BRAZILIAN CONSTITUTIONAL THEORY AND THE CONSTITUTION OF 1988: TO THE POST-POSITIVISM TO NEO CONSTITUTIONALISM
}

Antonio Cavalcanti Maia*

\section{Resumo}

O presente artigo busca demonstrar que o desenvolvimento de uma hermenêtica constitucional progressista impõe-se como uma das principais tarefas teóricas a serem realizadas pelas novas gerações de juristas.

Daqui para diante esta tarefa será realizada sob a égide do neoconstitucionalismo, norteado pela tese habermasiana de que os cidadãos podem considerar que a Constituição é um projeto coletivo visando à realização cada vez mais completa de um sistema de direitos fundamentais já estabelecidos e atentos para o sentido profundo do fenômeno total representado pela constitucionalização dos direitos.

Palavras-chave: Hermenêutica constitucional. Neoconstitucionalismo. Habermas. Constitucionalização dos direitos.

\begin{abstract}
This article seeks to demonstrate that the development of a progressive constitutional hermeneutics imposes itself as a major theoretical tasks to be performed by the new generations of jurists.

From here on this task will be performed under the aegis of neoconstitutionalism, guided by Habermas's thesis that citizens can consider that the Constitution is a collective project aiming at becoming a complete system of fundamental rights already established as the realization and deep sense the total phenomenon represented by the constitutionalization of rights.
\end{abstract}

Keywords: Constitutional Hermeneutics. Neoconstitutionalism. Habermas. Constitutionalization of rights.

Em homenagem a um

processualista carioca: meu pai.

A crescente exigência de razões no Direito é paralela ao desenvolvimento da democracia na Europa.

Aulis Aarnio 
Sumário: Introdução. I. Princípios jurídicos e pós-positivismo - A constelação teórica da década de 90. Intermezzo: Razão prática e argumentação. II. As transformações dos sistemas jurídicos contemporâneos: acerca do neoconstitucionalismo. II 1: teoria do Estado; II 2: teoria do direito; II 3: filosofia política. III. Neoconstitucionalismo: ensaios escolhidos. Adendo: o cânone neoconstitucional. IV. A motivação das decisões judiciais: C.F. art. 93IX - o princípio neoconstitucionalista. Conclusão.

\section{Introdução}

O amadurecimento da democracia no Brasil é um fato incontestável. Como característica cardeal desse modus vivendi, o novo papel representado pelo ordenamento jurídico na vida política e cotidiana dos cidadãos. Da incorporação na linguagem corriqueira de nossos concidadãos da existência de direitos a eles garantidos pela nossa Lei Maior, à onipresença de aspectos da vida das instituições jurídicas na TV - Ministério Público, Federal e Estadual, Tribunal de Contas, Polícia Federal etc. -; do espraiamento dos concursos públicos meritocráticos reestruturando o Estado brasileiro à constante presença na grande mídia, sobretudo paulista (Estado e Folha de São Paulo, no final de 2011 e início de 2012) do confronto entre Supremo Tribunal Federal (STJ) e o Conselho Nacional de Justiça (CNJ) através de sua corregedoria ${ }^{1}$. Correlato deste quadro supra o agigantamento do direito

\footnotetext{
* Professor de Filosofia de Direito da Universidade Estadual do Rio de Janeiro e de Filosofia Contemporânea da Pontifícia Universidade Católica da mesma cidade. Agradeço a meu amigo Alfonso Garcia Figueroa. Sem tudo o que aprendi em seus textos, em nossas conversas - tete-à-tete na Espanha no Brasil - e nas inúmeras vezes que contamos com a tecnologia telefônica contemporânea, não poderia assumir o tom tão assertivo apresentado em inúmeras passagens deste texto. Em especial nossas tratativas acadêmicas permitiram que corroborasse uma série de conclusões, confirmasse hipóteses e, acima de tudo, compartilhasse insights razoáveis acerca do pensamento jurídico contemporâneo. A minha falta de lastro em cultura jurídica não permitiria que assumisse uma posição tão enfática não fosse a identificação com o trabalho de Figueroa e todas as inúmeras leituras que fiz norteado pelo seu enfoque. Os enganos e o tom polemista, por vezes excessivo em face da requerida objetividade do trabalho acadêmico, são por minha conta. (Tomo a liberdade de fazer referência a uma parte da introdução de seu último livro, de 2009, Criaturas de la moralidad: una aproximación neoconstitucionalista al Derecho a través de los derechos, que testemunha este diálogo frutifico entre pensamento espanhol e brasileiro [sobre este diálogo confira também o anexo 1]. "Merece uma menção especial minha recente colaboração com alguns companheiros do Brasil, que estão impulsionando ali com invejável entusiasmo numerosos projetos relacionados com a filosofia jurídica em geral e com a metodologia neoconstitucionalista, em particular em torno da estimulante figura do professor Antonio Cavalcanti Maia, no Rio de Janeiro. Estou pensando nos professores Thomas Bustamante, Margarida Camargo, Claudio Pereira Neto e outros investigadores mais jovens como Eduardo Moreira que vêm desenrolando um fecundo trabalho do qual minha própria obra se tem beneficiado.")

${ }^{1}$ Durante o recesso do Judiciário em janeiro de 2012, diariamente a grande imprensa paulista (Estado e Folha de São Paulo) dedicou matérias ao conflito entre esses dois órgãos de nossa república. Um observador sociológico não poderia deixar de considerar essa pressão política na estreita maioria (seis a cinco votos), que garantiu a área de atuação do CNJ, vis a vi, os tribunais de justiça estaduais e suas respectivas corregedorias. ${ }^{2}$ Entre as inúmeras publicações realizadas em torno desta data saliento duas em que o debate acerca das problemáticas discutidas neste trabalho ocupam lugar de destaque. Em Vinte anos da Constituição Federal de
} 
constitucional em nosso país. Afinal, foi a nossa Constituição de 88, inspirada nas Constituições Ibéricas, e anterior à emergência do pensamento único - a partir da queda do muro de Berlim de 89 e da hegemonia da basófia neoliberal - que constituiu o solo fértil institucional-político-jurídico capaz de permitir às forças vivas da nação continuarem sua luta contra-hegemônica, em face do predomínio da lógica econômica de inspiração neoliberal, com vistas à construção de uma sociedade mais equitativa no Brasil.

Este repto à comunidade jurídica nacional demanda construir um aparato teórico capaz de, por um lado, estabelecer as condições de diálogo e interferência mútua com a vida política, e, por outro, compreender e operacionalizar de forma democrática, a interpretação e aplicação do direito que, com nosso Documento Político-Jurídico principiológico, alçou a atividade judiciária a novos patamares - colocando também em questão a permanente preocupação com a segurança jurídica, a racionalidade judicial e a legitimidade da ação do Judiciário, em especial em sede constitucional, quando o Supremo Tribunal Federal (STF) tornou-se, em inúmeros casos, uma espécie de "legislador intersticial".

A época do aniversário das duas décadas de nossa Carta Cidadã instou, naturalmente, a que se realizasse um balanço acerca do que foi alcançado neste período de experiência democrática, mas também a indagar quais perspectivas podem ser vislumbradas na busca de adequação do nosso aparato jurídico institucional às expectativas, necessidades e demandas de uma sociedade de massas democrática moderna. ${ }^{2}$ Continuar esta linha de análise: o desiderato deste trabalho. Cabe salientar nesta introdução o ponto de vista de análise aqui assumido: a partir de um ângulo interdisciplinar, onde considerações de natureza política convergem no exame de problemáticas que transitam no campo da filosofia do direito e política, da metodologia jurídica e do direito constitucional. Com efeito, trata-se do empenho em fomentar os estudos jurídicos em uma démarche - em consonância com a própria natureza da atividade de pesquisa acadêmica - que avance uma compreensão mais abrangente e politicamente sensível da vida do direito em nosso país.

A partir destas premissas, pode-se inquirir acerca da seguinte questão: até que ponto parcelas significativas de nossa comunidade jurídica encontram-se conscientes dos instrumentos teóricos disponíveis no campo da metodologia jurídica mais afeitos a uma práxis jurídica de sociedades democráticas contemporâneas? Afinal, como assevera Bonavides no prefácio de seu Curso de direito constitucional, "a mocidade acadêmica, a classe parlamentar, o meio forense e a cidadania ativa não podem ficar longe dos progressos doutrinários do Direito Constitucional". Deve-se acrescentar, nem tampouco dos avanços nos campos da metodologia jurídica, da filosofia política e do direito.

Assim, aqui se procura avaliar as possibilidades do emprego dos últimos desenvolvimentos da filosofia do direito, da metodologia jurídica e da hermenêutica constitucional - na cultura norte-atlântica - em nosso panorama jurídico-político. Impõe salientar uma preocupação de natureza política, cuja presença norteia todos os esforços teóricos aqui elaborados. Como a doutrina pode se empenhar em uma reflexão sobre o direito constitucional fornecedora dos instrumentos metodológicos aptos a explorar os

1988, (Rio de Janeiro, Lumen Juris) coordenado por Cláudio Pereira de Souza Neto, Daniel Sarmento e Gustavo Binenbojm, o debate sobre o movimento neoconstitucionalista ocupa posição de destaque na primeira parte do livro. (Naquela ocasião expus a primeira versão do texto agora aqui apresentado - revisto e aumentado - sob o título "Nos vinte anos da Carta Cidadã: do pós-positivismo ao neoconstitucionalismo"); e 20 anos da Constituição brasileira (São Paulo, Saraiva) coordenado por Eduardo Moreira e, Marcio Pugliesi. Nesta coletânea, tanto as reflexões sobre o neoconstitucionalismo como também as considerações acerca do póspositivismo, ocupam quase metade do livro. 
potenciais emancipatórios presentes em um texto constitucional, resultado de um processo de mobilização sem paralelo em nossa história, que nem de longe exauriu a suas capacidades de promover o funcionamento de uma ordem jurídica comprometida com a democracia.

O texto que ora apresento, num certo sentido, apresenta uma história dos esforços de construção de um enfoque teórico, por um lado, mais adequado à compreensão das transformações operadas nos sistemas jurídicos contemporâneos (tanto do ponto de vista interno - com questões relativas à metodologia de aplicação do direito, em especial dos princípios constitucionais -; como do ponto de vista externo, refletindo acerca do papel do direito e do Judiciário nos ordenamentos jurídicos contemporâneos). Por outro, carrega a preocupação de reconhecer os instrumentos capazes de operacionalizar, de forma mais racional possível, os novos elementos jurídico teóricos postos em movimento a partir dessas enormes modificações ocorridas nessas ultimas décadas. Modificações no âmbito estrito do direito constitucional, com a rematerialização do direito acarretada pela inclusão dos princípios jurídicos. Modificações mais amplas, no âmbito da filosofia - com a reabilitação da razão prática - que implicam consequências significativas à inteligência dos problemas postos em discussão no âmbito do estado democrático constitucional contemporâneo.

O primeiro item do texto objetiva traçar uma cartografia geral dos debates da década de 90. Assume um caráter mais descritivo e analítico e retrata uma realidade jurídica que parece já ter conquistado um grande grau de adesão entre os experts participantes do debate teorético em direito constitucional em nosso país. Já o segundo item, estribado no horizonte descrito na primeira parte, avança numa seara mais controversa, pois sustenta a emergência de um novo paradigma jurídico - o neoconstitucionalismo - assunto de tormentosa polêmica na doutrina nacional e estrangeira. Neste segundo momento, embora o texto também siga um viés descritivo analítico, há assumidamente uma tomada de posição na qual se advoga ser este novo quadro teórico mais apto à inteligência e funcionamento dos sistemas jurídicos avançados. Afinal, como salienta a figura chave deste movimento de ideias "isso mostra que o constitucionalismo discursivo (ou neoconstitucionalismo, do ponto de vista do debate Ibero-Ítalo-Latinoamericano - A.C. Maia) tem sua base não só em instituições e argumentos, mas, essencialmente, também em pessoas que o apóiam."2

Não poderia agora deixar de me escusar pela apresentação de, por vezes, inúmeras teses fortes presentes neste texto sem uma justificação mais alargada, contextualizada e sólida como deveriam sê-las tendo em vista a proposta/aposta apresentada neste trabalho. Entretanto, alguns esclarecimentos podem ser arrolados para uma mais crível sustentação da rede conceitual, argumentativa e bibliográfica aqui apresentada:

a) $\mathrm{Na}$ verdade este texto é o núcleo do livro que publicarei proximamente, retirando do título a palavra "sobre". Nele aprofundarei algumas das questões aqui ventiladas e reunirei uma série de artigos de minha autoria - mencionados na bibliografia e que constituem um grupo de estudos preliminares à posição aqui advogada.

b) Além disso, as teses filosóficas - como a reabilitação da razão prática, em especial na sua versão de corte kantiano-discursivo (Apel/Habermas/Alexy) e "a superação" do hiato entre ser/dever-ser - e as jusfilosóficas, como: o papel dos direitos humanos nas ordens jurídicas contemporâneas, a rearticulação das relações entre direito e moral, o papel

\footnotetext{
${ }^{2}$ ALEXY, Robert. Constitucionalismo discursivo. Porto Alegre, Livraria do Advogado, 2008, p. 16.
} 


\section{Quaestio Iuris}

c) civilizatório do direito, a e o patriotismo constitucional como doutrina legitimadora das democracias contemporâneas, foram detalhadamente expostas no livro de minha lavra Jürgen Habermas: filósofo do direito. Tive a oportunidade de publicá-lo em 2008, reunindo textos publicados naquela década, tendo como tese central (destacado na orelha do volume) "a exposição de elementos teóricos mobilizados por Habermas capazes de respaldar uma proposta teórica que se situa além do positivismo jurídico," (grifo no original).

d) Aprofundei, também algumas das questões já presentes no livro supramencionado em outros três artigos que complementaram e melhor alicerçaram a posição jusfilosófica assumida naquela ocasião: em 2008, "Acerca dos direitos humanos e o diálogo intercultural" e "Patriotismo constitucional e patriotismo republicano", em 2009, "Habermas/Alexy e o discurso prático" (referências completas na bibliografia).

$$
* * *
$$


I - Princípios jurídicos e pós-positivismo - a constelação teórica da década de 90.

\begin{abstract}
Uma vez que nós identificamos princípios legais como uma espécie diferente de standard das regras legais, nós subitamente nos damos conta de que eles estão a nossa volta em todos os âmbitos do mundo jurídico. Professores de direito os ensinam, os livros de direito os citam, os historiadores do direito os celebram. Mas eles parecem estar energicamente em funcionamento, carregando um maior peso, nos casos difíceis como Riggs and Henningsen. Em casos como este os princípios desempenham um papel essencial na argumentação que sustenta julgamentos acerca de obrigações e direitos legais particulares.
\end{abstract}

Ronald Dworkin

Nas últimas décadas, assistiu-se no Brasil um enorme florescimento dos estudos juspublicistas. Por um lado, a promulgação de nossa Constituição Federal, em 5 de outubro de 1988, obrigou ao desenvolvimento de toda uma nova dogmática constitucional; por outro, o amadurecimento de nossa vida universitária, sobretudo por meio da expansão e da consolidação de cursos de pós-graduação, elevou a um patamar mais sofisticado a reflexão teórica de nossa doutrina.

A Constituição Federal de 1988, de matriz principiológica, nitidamente inspirada nas Constituições Ibéricas - frutos dos vitoriosos movimentos democráticos da década de 70 -, introduziu uma nova configuração no âmbito do direito público: um texto que extravasa os limites do constitucionalismo tradicional, de corte liberal, albergando na Lei Maior um extenso elenco de direitos fundamentais, bem como incorporando, por meio dos princípios, opções valorativas e, por meio de diretrizes, compromissos políticos.

Já o amadurecimento de nossa cultura jurídica fez com que - como de hábito em países periféricos - passássemos a acompanhar atentamente as mais recentes tendências no âmbito doutrinário norte-atlântico. Nesse sentido, os juristas de nosso país não puderam se colocar à margem do enorme debate teórico travado no âmbito do direito constitucional (com a presença maciça de influxos jusfilosóficos), principalmente na Península Ibérica, na Alemanha e nos E.U.A. Esse debate tem como um de seus elementos cardeais o reconhecimento da centralidade dos princípios de direito na autocompreensão contemporânea dos sistemas jurídicos.

$\mathrm{Na}$ doutrina constitucional brasileira, essa nova constelação teórica, que reconhece ser a estrutura normativa composta de regras e princípios, foi primeiramente exposta, como já destacado, por Paulo Bonavides, apontando Ronald Dworkin e Robert Alexy como seus principais protagonistas. Para descrever essa nova configuração nosso venerando constitucionalista utilizou o termo "pós-positivista". A utilização desta rubrica se justificou na medida em que a incorporação dos princípios jurídicos e dos valores a eles atrelados implicou o abandono de uma das características principais do paradigma do positivismo jurídico - a não-conexão necessária entre direito e moral. Não se poderia continuar a descrever a situação atual do pensamento jurídico, em especial em sede constitucional, a partir da linguagem teórica positivista, posto que o reconhecimento da juridicidade dos princípios causa espécie à grade de inteligibilidade do fenômeno jurídico 
proposta por esse enfoque teórico. Com efeito, como afirma Zagrebelsky: "de acordo com a mentalidade do positivismo jurídico, as normas de princípio, ao conter fórmulas vagas, referências à aspirações ético-políticas, promessas não realizáveis por ora, esconderiam um vazio jurídico e produziriam uma 'contaminação das verdadeiras normas jurídicas com afirmações políticas, proclamações de boas intenções, etc."3

Entretanto, cabe destacar de inicio que a disseminação desta nomenclatura na doutrina brasileira ${ }^{5}$ pode provocar confusões a partir da identificação dessa constelação teórica com o chamado movimento "pós-moderno". Ora, uma das consequências do amadurecimento de nosso debate teórico no âmbito jurídico foi o rompimento com um certo insulamento vis-à-vis outras áreas das humanidades e das ciências sociais. Nas últimas duas décadas, quase que como um "bordão", a categoria de pós-moderno atravessou os mais diferentes domínios do saber, não deixando de influenciar também o mundo do direito, em especial no momento em que nossa comunidade de pesquisadores se abre, saudavelmente, às demandas da interdisciplinaridade.

No entanto, embora não possa tratar aqui ${ }^{4}$, com a devida profundidade, de um tema dessa complexidade, devo destacar que o movimento de ideias jurídicas capitaneado por Dworkin e Alexy não pode ser confundido com o chamado pós-modernismo, quer seja com aquela vertente de nítida inspiração francesa, marcada pela matriz nietzschiana, ou com aquela proveniente dos quadrantes referenciados à teoria sistêmico-funcionalista. Pode-se até considerar que a cultura ocidental atingiu um novo patamar de época, implicando a utilização de outra categoria histórica (o que não poderia tratar no âmbito deste artigo), contudo, as características e teses defendidas pelos autores pós-modernos são divergentes dos pressupostos teóricos básicos do pós-positivismo. Para resumir em uma frase: os autores pós-modernos não acreditam na existência de uma racionalidade prática, ideia sem a qual não se poderia propor uma nova forma de compreensão do fenômeno do direito nas sociedades contemporâneas para além do positivismo jurídico.

Importa sublinhar que a constelação teórica denominada pós-positivista situa-se em uma posição bem distinta de qualquer corrente tributária da matriz pós-moderna. De plano, posso afirmar, estribado em um dos líderes do movimento que se insurge contra a hegemonia do positivismo jurídico, Aleksander Peczenik, que "a ideia que rege o pensamento jurídico desenvolvido ao longo de muitos séculos pela prática dos tribunais, os advogados e os juristas europeus tem que ser racional. Esta ideia é profundamente

\footnotetext{
${ }^{3}$ ZAGREBELSKY, Gustavo. El Derecho dúctil. Ley, derechos, justicia.. Madrid, Editorial Trotta, 1995, p.112. 5

Por exemplo, DANTAS, David D. Interpretação constitucional no pós-positivismo. São Paulo, Madras, 2004; OLIVEIRA JÚNIOR, José Alcebíades de. “Casos difíceis no pós-positivismo”. In: BOUCAULT, Carlos E. de Abreu; RODRIGUEZ, José Rodrigo. (org.). Hermenêutica plural. São Paulo, Martins Fontes, 2002; e BARROSO, Luís Roberto. "Fundamentos teóricos e filosóficos do novo direito constitucional brasileiro (Pósmodernidade, teoria crítica e pós-positivismo)". In: Revista Diálogo Jurídico. Salvador: CAJ - Centro de Atualização Jurídica, v. I, no 06, setembro, 2001.

${ }^{4}$ Quanto ao diferendo entre os pós-modernos e Dworkin e Alexy, podemos resumi-los em uma tese: o reconhecimento da credibilidade da razão prática de corte construtivista kantiano. Quanto aos primeiros, enredados em uma posição relativista, refutam qualquer possibilidade da credibilidade de um ponto de vista transcultural que vá alem dos limites paroquiais de cada especifica forma de vida; quanto aos segundos, alicerçados nos projetos filosóficos de Rawls e Apel/Habermas, abrem o campo de um pensamento jurídico que está além da estiolada querela jusnaturalismo versus positivismo. Quanto à questão da razão prática vejase também o intermezzo deste texto que traz elementos a melhor compreensão desta problemática.
} 
conservadora; o que se passa é que não posso imaginar que gerações e gerações de pessoas que participaram de uma prática tão importante como é a do direito possam ter sofrido algo da ordem de um engano coletivo. Nesse sentido, minha concepção é diametralmente oposta à de alguns movimentos críticos, tais como os Critical Legal Studies, o Realismo jurídico, o Desconstrutivismo e o Pós-modernismo."5

A fim de especificar melhor o que significa a abordagem caracterizada na década de 90 como do pós-positivista, desenvolverei uma caracterização geral desta constelação teórica. Respaldarei meu trabalho, sobretudo, nas elaborações desenvolvidas por Albert Calsamiglia e tendo como foco de análise a obra de Ronald Dworkin. Em primeiro lugar, cabe esclarecer que Calsamiglia, em preciosa introdução à edição de Taking Rights Seriously em espanhol, não só oferece uma admirável síntese desta obra capital, bem como a articula - sustentando suas teses básicas - em face do debate hispano-americano. Em especial, vis à vis, os atilados positivistas argentinos como Carrió. Em segundo lugar, o posicionamento de Paulo Bonavides se assemelha à démarche dworkiniana (mais do que o projeto de Alexy, referência principal das considerações da segunda parte deste trabalho). Tanto Dworkin como Bonavides convergem no sentido de uma virada hermenêutica observada nos estudos jus-teoréticos nas décadas de 70/80, ressaltando a especificidade de uma hermenêutica renovada e marcando como incontornável o aspecto de objeto cultural do direito.

Esclareça-se que não tratarei neste momento de um outro autor-chave dentro do que se caracteriza na dogmática constitucional contemporânea brasileira, como póspositivismo: Robert Alexy. Afinal, embora não se auto-classifique explicitamente como póspositivista - Alexy denomina a sua démarche teórica não-positivista ${ }^{6}$-, aceitou tal qualificação de pós-positivista em entrevista recente no Brasil. ${ }^{9} \mathrm{Na}$ resposta à questão por mim endereçada temos a seguinte explicação acerca de sua posição pós-positivista articulando-a com duas ideias-chave: "textura aberta da linguagem" e "pretensão de correção". Como afirma o jusfilósofo Kiel,: "Não há outra opção que não seja a de preencher a textura aberta de acordo com a pretensão de correção; que necessariamente inclui uma pretensão de justiça. Isto torna necessária a relação entre direito e moral. Se vocês quiserem chamar isto de pós-positivismo, por favor, o façam." Na mesma passagem há outras esclarecedoras informações:

Todos estes conceitos opostos são difíceis e devem ser usados com cuidado. Naturalmente, o conceito de pós-positivismo pode encontrar significado em dois sentidos: sempre fui profundamente influenciado especialmente por Hans Kelsen, Herbert Hart e Alf Ross, que são todos positivistas. Eu nunca desistiria do que aprendi com eles. Neste aspecto, penso que estamos todos sustentados nos ombros dos grandes positivistas do século XX. Mas não é suficiente ser um positivista, porque a lei positiva, que é o primeiro passo, suscita uma pretensão de correção. E não é a partir de um ponto de vista metafísico externo que trago a pretensão de correção para o campo jurídico. A pretensão de correção já se encontra na lei positiva, está sempre implícita na lei positiva e alcançou enorme importância devido ao que

\footnotetext{
${ }^{5}$ PECZENIK, Aleksander. "Introducción”. In: Derecho y razón. México, Fontamara, 2000, p. 07.

${ }^{6}$ No livro El concepto y la validez del Derecho, Barcelona, Gedisa, 2004, p. 61, Alexy afirma, referindo-se ao seu próprio enfoque: “(...) o conceito de direito não-positivista nega caráter jurídico somente em casos de extrema injustiça." 9

Em entrevista realizada por Alice Wolf, no Ceará, em março de 2002, publicada na Revista Trimestral de Direito Civil (Rio de Janeiro, Ed. Padma, ano 4, vol. 16, 2003, pp. 311-320). Saliente-se também que na monumental coletânea Le positivisme juridique, organizada por Christophe Grzegorczyk, Françoise Michaut e Michel Troper, publicada em Paris, LGDJ, 1992, Robert Alexy, Alexander Peczenik e Aulius Aarnio são classificados como pós-positivistas (No texto 29 da coletânea, pp. 159-162).
} 


\begin{abstract}
Hart intitula "textura aberta", ou seja, a textura aberta de cada e toda lei positiva. A pretensão de correção constitui no direito em uma pretensão de justiça, porque a justiça não é nada além do que uma distribuição correta e balanceamento. Se pusermos ambas juntas, a pretensão de correção e a textura aberta da lei, poderemos ver que a lei positiva é, de um lado, importante para a democracia por razões democráticas, pois, em uma democracia, a lei positiva está procedimentalmente justificada pelo processo democrático público, o qual dá os contornos à lei positiva; mas contudo, sempre existe, por outro lado, uma pretensão de correção e uma textura aberta (...) Este conceito [pós-positivista, ACM] se refere a uma relação histórica de minha teoria com o positivismo e não com a relação lógica entre ambos. Não se pode pôr de lado a lei positiva, mas é necessário incorporar a lei positiva em uma justificação moral. A lei positiva é necessária por razões morais, pois se não tivéssemos a lei positiva, estaríamos não somente sem a segurança e eficiência legal, mas também sem a proteção dos direitos que são requeridos pela moralidade. Por outro lado, desde o momento que temos a lei positiva, no interior desta, a moralidade é necessária. Então há uma necessidade moral externa de lei positiva e uma necessidade interna de moralidade no interior da lei positiva.
\end{abstract}

Nesta importante e esclarecedora passagem, há o destaque de duas categorias centrais à inteligência da nova compreensão proposta do fenômeno jurídico pela obra de Alexy - textura aberta da linguagem e pretensão de correção - constituidoras do que se veio a chamar não-positivismo (principiológico), pós-positivismo e, mais adiante, neoconstitucionalismo. Sobre Alexy, em geral, e sobre a pretensão de correção, mais considerações serão expendidas ao longo deste trabalho (no item sobre argumentação, presente no Intermezzo, na parte relativa a Habermas). A referência à textura aberta da linguagem permite que sejam feitas algumas considerações acerca da obra de Herbert Hart, a partir da qual se desdobrará boa parte do debate acerca do pós-positivismo - com o surgimento do positivismo inclusivo e do positivismo exclusivo (mais considerações sobre esta distinção serão elaboradas mais a seguir neste trabalho). Saliente-se também que a categoria pós-positivistas surgiu no cenário de ideias norte-atlântico primeiramente na cultura anglo-saxônica: com, por um lado, a respeitosa, porém devastadora crítica de Ronald Dwokin ao mestre de Oxford; e por outro, com a apresentação em 1986, da teoria neoinstitucional do direito de Neil MacCormick ${ }^{7}$ e Ota Weinberger, no livro Institutional Theory of Law. (Quanto a essa dupla proveniência do pós-positivismo, sigo Carla Faralli.

\footnotetext{
${ }^{7}$ Não terei oportunidade neste momento de abordar a obra de Neil MacCormick. Contudo é crucial seu papel na mudança paradigmática que ensejou o fim da hegemonia do positivismo jurídico - na sua mais refinada versão, hartiana - no mundo anglo-saxônico. Segundo esclarecedora entrevista, pouco antes da morte do jusfilósofo de Edimburgo, (ATIENZA, Manuel. "Entrevista a Neil MacCormick" In: Doxa. Cuadernos de filosofia del Derecho, $n^{\circ} 29,2006$ ), temos que a sua obra, de início um desdobramento das ideias apresentadas na arquitetônica teórica de Hart ao campo específico da argumentação jurídica (legal reasoning), avança juntamente com o trabalho de Ota Weinberger, no inicio dos anos 80 para uma posição singular no debate jusfilosófico com a teoria neoinstitucional do direito. No início daquela década, o filósofo escocês se afasta das posições mais próximas do positivismo jurídico de seu colega austríaco. Influenciado por Chaïm Perelman e, também, como ele afirma na segunda edição de seu livro Argumentação jurídica e teoria do direito, (São Paulo, Martins Fontes, 2006), pela teoria discursiva do direito e da democracia: "Como indiquei no início deste Preâmbulo, fui convencido por Robert Alexy (e, por conseguinte por Jürgen Habermas) de que pode ser construída uma explanação do discurso racional prático que chegue a uma justificação para instituições legais e para a argumentação jurídica a partir das exigências da razão geral prática, e que submeta totalmente a argumentação jurídica aos princípios gerais da racionalidade prática. Isso não significa nem acarreta necessariamente que o direito sempre seja, ou sempre possa ser, perfeitamente determinado; ou que a razão prática possa fornecer respostas determinadas sempre que o direito deixe de estipular uma resposta. Mas significa, sim, que a postura humiana adotada no meu último capítulo precisa ser radicalmente reexaminada." (p. XIX). Para uma brilhante síntese do trabalho de MacCormick, focalizando a problemática do póspositivismo e defendendo a posição do jusfilósofo escocês como um autor alinhado a um novo paradigma, superador do positivismo jurídico, temos o artigo de Thomas da Rosa Bustamante, "Comment on Petroski On MacCormick’s Post-Positivism”. In: German Law Journal, vol. 12, nº 2, 2011.
} 
(In: La filosofía del Derecho contemporánea: Los temas y desafíos. Bogotá, Universidad Externado de Colombia, 2007, p. 14).

Herbert Hart: figura cardeal da cultura jurídica novecentista. Devemos a ele, entre outras coisas, uma reformulação e sofisticação do positivismo jurídico, com a incorporação no arsenal teórico de trabalho dos juristas de todo um léxico inspirado no discurso filosófico. Em primeiro lugar, no esforço central da jurisprudência (no sentido de teoria geral do direito) de descrever, classificar e compreender as estruturas das regras dotadas de coação, determinantes do comportamento social, a explicitação da diferença entre "regras primárias de obrigação e regras secundárias de reconhecimento, alteração e julgamento." ${ }^{\circ}$ Em segundo lugar, a introdução no âmbito da filosofia do direito, especialmente na conturbada problemática concernente aos debates acerca da fundamentação do direito, da ideia de uma "regra de reconhecimento, que faculta os critérios através dos quais a validade das outras regras do sistema é avaliada (...)", , recolocando num patamar mais complexo e defensável o 'calcanhar de Aquiles' da perspectiva positivista kelseniana - a norma fundamental. Em terceiro lugar, a noção de textura aberta da linguagem. ${ }^{10}$ As reflexões concernentes à textura aberta da linguagem provêem de uma das inúmeras 'quase geniais' aberturas propiciadas ao debate filosófico contemporâneo por Wittgenstein. Sistematizada por um dos mais próximos membros de seu influente círculo de pupilos, Friedrich Waismann, tal discussão se coadunou perfeitamente com uma das preocupações nucleares da interpretação jurídica, vale dizer, o problema sempre presente da indeterminação linguística, problema este que no domínio do direito, pela imperiosa necessidade de univocidade conceitual e pelas inúmeras consequências fáticas que a aplicação das normas legais trazem à vida quotidiana, revestiuse sempre de grande importância. Herbert Hart, em seu notável esforço de desenvolver uma nova abordagem à inteligência da ordem jurídica, elaborou a perspectiva da jurisprudência analítica, integrando os desenvolvimentos da chamada filosofia da linguagem ordinária, depois do linguistic turn ${ }^{11}$ derivada do trabalho do 'segundo' Wittgenstein, capitaneado por

\footnotetext{
${ }_{9}^{8}$ HART, Herbert. O conceito de direito. Lisboa, Calouste Gulbenkian, 1986, p.169.

9 . Ibid p. 117.
}

${ }^{10}$ Sobre esta problemática confira-se STRUCHINER, Noel. Direito e linguagem: uma análise da textura aberta da linguagem e sua aplicação ao direito. Rio de Janeiro, Renovar, 2002. Alguns destes parágrafos sobre Hart aqui incluídos fazem parte do texto publicado como "Considerações introdutórias", sob o título "Textura aberta da linguagem e interpretação jurídica: considerações acerca da tese da autoctonia do discurso jusfilosófico" neste livro supracitado. Para uma esclarecedora leitura de Hart na literatura nacional, temos BARZOTTO, Luis Fernando. O positivismo jurídico contemporâneo: uma introdução a Kelsen, Ross e Hart. São Leopoldo, UNISINOS, 1999, pp 107-136.

${ }^{11}$ Em relação a essa complexa problemática, em especial no que tange ao enfoque privilegiado nesta pesquisa, não poderia circunscrevê-la melhor (pedindo escusas ao leitor pela extensão da citação) do que Manoel Maria Carrilho: "Com o linguistic turn, a filosofia situou-se ainda numa linha de continuidade com a tradição crítica que via no conhecimento a priori o seu objeto de eleição e na análise do entendimento ou da experiência a sua principal tarefa. Mudou-se de registro, da consciência para a linguagem, mas conservou-se o resto, nomeadamente o objetivo de fazer da filosofia uma disciplina que se ocupa de princípios estruturais, atemporais e a-históricos, do conhecer e do agir. Wittgenstein enunciou, ao abandonar as suas concepções logicistas, e ao elaborar essa espécie de 'tractatus rethoricus-philosophicus' em que consistem as suas Investigações filosóficas, os limites da compreensão formalista da linguagem, sublinhando que são muitas as situações em que ela não é passível de ser analisada em termos de valores de verdade e de falsidade e que, mesmo quando tal ocorre, isso implica que se pressuponha, já na compreensão dos enunciados, a univocidade que se pretende obter como resultado da análise. A valorização da linguagem corrente e a descrição dos seus usos foram a via alternativa que Wittgenstein propôs, e em que a seu modo se situaram primeiro Austin e depois Searle. Com eles - mas também com Strawson e Grice - é possível falar de uma ruptura pragmática que, apontando para o corte com o paradigma representativo, impôs a idéia de que a linguagem é ação e de que 
John L. Austin, Gilbert Ryle (cujo seminal trabalho de 1953, The Concept of Mind inspirou o título do principal trabalho de Hart) e John Searle.

Devemos ter em mente que o trabalho do jusfilósofo de Oxford segue o mote wittgensteiniano, lapidado por outro de seus diletos colaboradores, Peter Winch: "A ideia é que, tão logo se termine esse trabalho de reaparelhamento do instrumental filosófico, o dever do filósofo é retornar à sua tarefa mais importante - de esclarecer os conceitos que pertencem a outras disciplinas não-filosóficas." ${ }^{12}$ Assim, inúmeros veneráveis problemas da tradição jurídica são redimensionados no trabalho de Hart, quiçá no mais frutífero enriquecimento mútuo observado (até o surgimento das figuras de Ronald Dworkin e Robert Alexy) entre filosofia e teoria do direito. Esta profunda articulação entre filosofia e direito foi atingida na obra hartiana como em poucos momentos da história do pensamento jusfilosófico. Quanto às implicações da noção textura aberta da linguagem, é palmar a sua utilidade a uma melhor inteligibilidade da prática jurídica, posto que "o direito instaura modelos de comportamento que inevitavelmente envolvem uma parte de indeterminação e que, deste fato, não podem se autoaplicar, a não ser através de uma interpretação cuja chave eles próprios não fornecem." ${ }^{16}$ Ademais, a indeterminação linguística causada pela textura aberta da linguagem acarreta lacunas e incompletudes, gerando em muitas ocasiões os hard cases, casos difíceis, insólitos, controversos, no limite não rotineiros - epicentro das discussões de metodologia jurídica após a respeitosa crítica formulada a Hart por Ronald Dworkin em "Is Law a Sistem of Rules?", de 1977. No tocante a esse esforço de Hart de renovar as abordagens no campo do direito, oportuna a descrição de um dos mais próximos colaboradores (do início dos anos 60 até 81) e depois crítico.

Ele [Hart] buscou um novo caminho para a explicação das regras sociais, dependente do que está na moda agora (e eu acredito que é útil) chamar de abordagem hermenêutica. Esta abordagem deve muito à sua apreciação e uso da análise linguística praticada por seu amigo e contemporâneo J. L. Austin, e a temas avançados no livro de Peter Winch A idéia de ciência social. Através do trabalho de Winch, Hart conecta com a filosofia linguística posta em movimento por Ludwig Wittgenstein em seus últimos anos e também com a insistência de Max Weber, como um sociólogo, da necessidade de uma compreensão interpretativa, assim como uma descrição comportamental das ações e instituições sociais. Apesar de considerável seu débito a esses predecessores, a teoria das regras sociais de Hart e a consequente compreensão das regras legais como um tipo especial de regras sociais é uma nova e original concepção, com grande potencialidade para desenvolvimentos posteriores e aperfeiçoamentos. $^{13}$

o seu sentido depende sempre do contexto em que ocorre." CARRILHO, Manuel Maria. O que é filosofia. Lisboa, Difusão Cultural, 1994, pp. 76-77.

${ }^{12}$ WINCH, Peter. A idéia de uma ciência social e sua relação com a filosofia. São Paulo, Companhia Editora Nacional, 1970 , p. 17.16

PICAVET, Emmanuel. Kelsen et Hart. La norme et la conduite. Paris, Presses Universitaires de France, 2000 , p. 126.

MACCORMICK, Neil.. H.L.A. Hart. Stanford, Stanford University Press, 1981, p. 29. Cabe destacar também que a constelação de pensamento aberta a partir dos anos 50 - tributária da reflexão acarretada no discurso filosófico pelos desenvolvimentos da filosofia da linguagem ordinária - encontra-se no mesmo diapasão de perspectivas filosóficas que têm tido enorme impacto no pensamento jurídico das últimas décadas, como as de Toulmin, Perelman e Habermas, filósofos que, segundo Thomas Comley, "também compartilham algo mais especifico, talvez mais profundo e importante: uma determinação em combater o dogma, em relacionar a filosofia com o a vida quotidiana, e em ancorar filosofia na controvérsia (grifo no original)". In: 
A inclusão de Hart no desenvolvimento deste trabalho faz-se necessária tendo em vista que sua forma de positivismo - soft, hermenêutico, - já denota um abrandamento nas posições positivistas mais ortodoxas de Kelsen, e abre o campo, com o posfácio póstumo de 92 , do $\mathrm{O}$ conceito de direito, para o chamado "positivismo inclusivo"14. A sua obra pode ser entendida como a pavimentação de um caminho de distanciamento das posições positivistas mais ortodoxas. Tal denominação, o "positivismo inclusivo", foi adotada por um continuador de sua obra, o jusfilósofo canadense Wilfred Walluchov em 1994. (Há de se mencionar também a versão do professor de Yale, Jules Coleman, também na esteira das mudanças do trabalho de Hart, apresentadas na segunda edição de seu livro, dando origem ao "positivismo incorporacionista"). Tal discussão assume importância para todos os desdobramentos deste debate apresentado nesta pesquisa, na medida em que o "positivismo inclusivo" se encontra em diálogo com a corrente neoconstitucionalista não-positivista capitaneada por Alexy. Inclusive, o que justifica (como será melhor exposto mais adiante) o título Neoconstitucionalismo(s), primeira das coletâneas (2003) organizadas por Miguel Carbonell sobre este novo movimento jurídico. O uso do plural permite que estejam subsumidas ao rótulo neoconstitucionalista, por um lado não só aos trabalhos teóricos de Alexy (e Dworkin em última instância) e de todos os seus inúmeros seguidores, e, por outro, toda a linhagem de autores filiadas ao positivismo jurídico anglo-saxônico - em especial de inspiração hartiana, em seu aggiornamento em face da atual conjuntura do pensamento jusfilosófico.

Retornando à obra Alexy, depois desta espécie de digressão no ambiente do positivismo e pós-positivismo britânico, posso afirmar que seu trabalho apresenta-se como o esteio do neoconstitucionalismo europeu contemporâneo. Aspectos da sua empresa, com mais vagar, serão apresentados na segunda parte (item II) desta pesquisa. A referência à obra do professor de Kiel se faz necessária na medida em que também é desiderato desta investigação distinguir o campo teórico coberto pelo pós-positivismo jurídico do movimento pós-moderno. Ora, o empreendimento jusfilosófico de Alexy vincula-se constitutivamente ao projeto da "ética do discurso", já que "o não-positivismo pressupõe, pelo menos, uma ética rudimentária, não relativista"19 A ética do discurso, elaborada por Karl-Otto Apel e Jürgen Habermas, parte de uma reabilitação da racionalidade prática de corte kantiano. Tal ideia é completamente estranha a qualquer dos autores pós-modernos, infensos a toda espécie proposta de ética universalista. Ademais, tanto Apel quanto Habermas, sobretudo, têm caracterizado seu posicionamento filosófico por uma reprovação contínua e consistente dos pressupostos relativistas dos autores pós-modernos, bem como o abandono de uma noção de razão que vá além da racionalidade instrumental (regida pela lógica custo/benefício) propugnado por esses mesmos autores.

Não focalizarei, especificamente, neste artigo, aspectos da obra de Ronald Dworkin relativos à problemática concernente à (não) relação entre pós-positivismo jurídico e pós-modernidade. O filósofo norte-americano certamente não se reconhece como

COMLEY, Thomas M. Rhetoric in the European Tradition. Chicago, The University of Chicago Press, 1990, p. 304.

${ }^{14}$ Sobre esta nova categoria do pensamento jurídico que será objeto de algumas considerações a seguir neste trabalho, confira-se verbete WALLUCHOV, Wilfrid. "Legal Positivism, Inclusive versus Exclusive" In: E. Craig (ed.), Routledge Encyclopedia of Philosophy. Londres, Routledge, $2008{ }^{19}$ ALEXY, Robert. El concepto y la validez del Derecho. Op. cit. p. 59.

Revista Quaestio luris, vol.04, no01. ISSN 1516-0351 p.1-86 
pósmoderno, como ele me respondeu pessoalmente em uma oportunidade que tive de conversarmos, em outubro de 2001, em Nova Iorque. Quanto à sua inclusão na categoria de pós-positivista, não parece ser necessário muito esforço para justificá-la. É notório que o próprio posicionamento de Dworkin surge como uma crítica ao positivismo hermenêutico de matriz analítica de Herbert Hart. Sendo assim, é evidente que a sua empresa teórica se coloca para além do positivismo jurídico. Como salienta o filósofo estadunidense: "devemos permanecer com os positivistas que insistem que é sempre somente uma questão de fato o que o direito é. Ou, devemos voar com o mais extremo dos advogados jusnaturalistas, que diz que não há diferença entre princípios de direito e princípios da moralidade. Mas tanto uma quanto outra dessas visões extremas estão erradas." ${ }^{15}$

A utilização do termo "pós-positivista" para designar a configuração contemporânea do pensamento jurídico implica, necessariamente, uma ruptura com a forma básica de compreensão do direito, hegemônica ao longo de boa parte do século XX, conhecida como positivismo jurídico. A necessidade da utilização de uma nova categoria terminológica decorre do rompimento de algumas das premissas básicas da teoria que - não obstante as suas diferentes feições - apresenta um denominador comum capaz de garantir sua coerência. Embora na doutrina nacional ainda não haja uma elaboração mais consistente deste novo cenário, uma figura de proa do pensamento jusfilosófico espanhol, Albert Calsamiglia, desenvolveu aguda análise desta problemática. Segundo o autor, só pode ser considerado pós-positivista quem ataca alguma das teses fundamentais do positivismo jurídico: "em primeiro lugar, a defesa da teoria das fontes sociais do direito e em segundo lugar, a tese da separação entre o direito, a moral e a política." ${ }^{21}$ Quanto a essa primeira tese, o positivismo jurídico não reconhece entre os materiais normativos capazes de determinar os comportamentos sociais, elementos que não tenham sua origem nos próprios fatos sociais. Vale dizer, como salienta Joseph Raz, corifeu do positivismo contemporâneo "o que é e o que não é direito é uma questão de fatos sociais." "16 Sendo assim, princípios, em boa parte dos casos oriundos de noções de natureza moral, e funcionando também como razões para decidir, não se encontram contemplados na grade teórica proposta pelo positivismo jurídico. Quanto à segunda tese, da separação entre direito, moral e política, tem-se que o reconhecimento da centralidade dos princípios jurídicos altera a forma como é pensada a relação entre essas três esferas da vida social, não mais de separação absoluta, como no caso do positivismo jurídico, mas de articulação complementar ${ }^{17}$, em que se procura respeitar as

\footnotetext{
${ }^{15}$ DWORKIN, Ronald. “A Reply to Critics”. In: Taking Rights Seriously. Cambridge, Harvard University Press, 1978, p. 342. 21

CALSAMIGLIA, Albert. "Pospositivismo". In: Doxa - Cuadernos de Filosofia Del Derecho, n. 21-I, 1998, p. 210.

${ }^{16}$ RAZ, Joseph. La autoridade del Derecho. México, D.F: UNAM: 1982, pp. 55-56, apud. FIGUEROA, Alfonso García. Principios y positivismo jurídico. El no positivismo principialista en las teorías de Ronald Dworkin y Robert Alexy. Madrid, Centro de Estúdios Políticos y Constitucionales, 1998, p. 45.

${ }^{17}$ No caso de Habermas, e também de Alexy, pode-se pensar numa complementaridade tensional entre direito e moral, como sugere Flávio Beno Siebeneichler, em "Uma Filosofia do direito procedimental". In: FREITAG, Bárbara (org.). Jürgen Habermas: 70 anos. Rio de Janeiro, Tempo Brasileiro, 1999, pp. 153-172. Atente-se também para o fato de que o enfoque da teoria discursiva do direito e da democracia não aposta nem em uma moralização do direito nem em uma jurisdicização da ética, mas sim em uma politização de ambas as esferas de
} 
especificidades desses três âmbitos mas se reconhece a impossibilidade de tratá-los de forma segmentada.

Um outro aspecto destacado por Calsamiglia, que gostaria de endossar dentro da abordagem sustentada neste trabalho, é o seguinte: falar de pós-positivismo não significa adotar uma posição radicalmente anti-positivista, mas sim propugnar por uma superação desta démarche teórica na busca de uma compreensão mais "afinada" da vida jurídica contemporânea. Ora, por um lado, não podemos nos recusar a reconhecer as incontornáveis contribuições dadas pelos juristas filiados ao positivismo jurídico à inteligência da estrutura da norma jurídica, bem como sua preocupação com a clareza, a certeza e a objetividade no estudo do direito (sem contar os exaustivos estudos acerca dos problemas das lacunas legais e antinomias), tudo isso referenciado à preocupação central dos estados de direito contemporâneos com a segurança jurídica; ademais, toda teorização acerca do ordenamento jurídico, ancorado no juspositivismo italiano, se incorporou incontornavelmente no arsenal do pensamento jurídico contemporâneo. Por outro lado, advogar um enfoque pós-positivista não significa defender - como é, por vezes, salientado por autores críticos a esse posicionamento - um retorno a posições jusnaturalistas devedoras de concepções metafísicas incompatíveis com o atual estágio de compreensão científica (não nos esqueçamos que as duas principais referências filosóficas ensejadoras do quadro no qual se desenvolve o travejamento teórico pós-positivismo, Jürgen Habermas e John Rawls, operam no âmbito pós-metafísico).

A seguir, destacarei cinco aspectos que caracterizam esse novo quadro teórico pós-positivista: a) deslocamento de agenda; b) a importância dos casos difíceis; c) o "abrandamento" da dicotomia descrição/prescrição; d) a busca de um lugar teórico para além do jusnaturalismo e do positivismo jurídico; e) o papel dos princípios na resolução dos casos difíceis.

\section{a) Deslocamento de agenda}

Como sustenta Calsamiglia, "creio que para além da superação do positivismo estamos frente a um deslocamento da agenda de problemas que interessam (...)." ${ }^{18}$ Esse "deslocamento" da agenda de problemas aponta para três eixos onde se concentram os esforços dos juristas pós-positivistas: a importância dos princípios gerais do direito, a relevância crucial da dimensão argumentativa na compreensão do funcionamento do direito nas sociedades democráticas contemporâneas e a reflexão aprofundada sobre o papel desempenhado pela hermenêutica jurídica. Por conseguinte, deixa-se de lado o foco privilegiado pelos autores positivistas - a estrutura lógica das normas e a completude do ordenamento jurídico. Ademais, o jurista passa a agir mais preocupado com as soluções futuras para os inúmeros e crescentes problemas enfrentados pela ordem jurídica, afastando seu olhar - como no caso do positivismo jurídico - de um enfoque voltado para o passado, preocupado com a estrutura da ordem legal e com os procedimentos garantidores da

normatização da vida social. No caso de Dworkin, a preocupação com a distinção entre a esfera da moral e do direito não é tão relevante; e é claro que os princípios jurídicos funcionam como um elemento de ligação entre direito e moral. Considerações a respeito da vexata quaestio da filosofia do direito serão também rapidamente mencionadas no Intermezzo.

${ }^{18}$ CALSAMIGLIA, Albert. "Postpositivismo". Op. cit., p. 210. 
legalidade das normas vigentes, como, por exemplo, a norma fundamental ou o "teste do pedigree".

\section{b) A importância dos casos difíceis}

Uma das principais características do pós-positivismo reside na relevância dada aos hard cases. Tais situações geram um momento especial para a teoria do direito, posto que esses casos difíceis, como afirma Alexy, "são sensores por meio dos quais pode ser estabelecida a natureza do direito." ${ }^{19}$ Assim, muda-se o foco de interesse dos teóricos em direção a situações não claramente cobertas pelo ordenamento jurídico entendido exclusivamente como um sistema de normas-regras (à feição positivista). Dessa forma, como já destacado, há um deslocamento da agenda de preocupações norteadoras das investigações teóricas, como mais uma vez aponta Calsamiglia: "se desloca o centro de atenção dos claros ou fáceis aos casos difíceis. O que interessa não é tanto investigar as soluções do passado e sim resolver os conflitos que ainda não foram resolvidos." ${ }^{20}$ Esses casos difíceis, controversos, insólitos, no limite, não rotineiros se apresentam quando as práticas legais existentes não fornecem uma resposta definitiva, quer seja porque surge uma incerteza em face das várias normas que podem ser aplicadas ao caso concreto, ou apresenta-se uma antinomia entre normas, ou, ainda, (em casos mais raros) haja uma lacuna legal. Manuel Atienza, apoiado em Neil MacCormick, lista a seguir quatro possíveis tipos de problemas jurídicos que ensejam casos difíceis (cabe lembrar que tais problemas não são estanques, na medida em que admitem diversas combinações e concorrências entre si). Em primeiro lugar, problemas de relevância, quando nos deparamos com dúvidas acerca de qual norma aplicar ao caso; segundo, problemas de interpretação, oriundos do fato de que surgem dúvidas de como estender uma norma (ou normas) aplicável ao caso; em terceiro lugar, problemas de prova, quando há um questionamento acerca da ocorrência ou não de um determinado fato; por fim, problemas de qualificação, "que surgem quando existem dúvidas sobre se um determinado fato que não se discute cai ou não sob o campo de aplicação de um determinado conceito contido no suposto de fato ou na consequência jurídica da norma." ${ }^{21}$

\footnotetext{
${ }^{19}$ ALEXY, Robert. “On Necessary Relations Between Law and Morality”. In: Ratio Iuris, vol. 3, n. 2 (julho 1989) apud FIGUEROA, Alfonso García. Princípios y positivismo jurídico.op. cit., p.55.

${ }^{20}$ CALSAMIGLIA, Albert. "Postpositivismo". Op. cit., p. 211.

${ }^{21}$ ATIENZA, Manuel. “Argumentación Jurídica”. In: VALDÉS, Ernesto Garzón; LAPORTA, Francisco J. (org.). El derecho y la justicia. Madrid, Trotta, 2000, p. 236. Também sobre casos difíceis, salienta Calsamiglia: "um caso é difícil se existe incerteza, seja porque existem várias normas que determinam sentenças distintas porque as normas são contraditórias -, seja porque não existe norma exatamente aplicável." CALSAMIGLIA, A. "Ensayo sobre Dworkin". In: Los derechos en serio, Barcelona, Ariel, 1997, p. 13. Entre nós, afirmam Barroso e Barcellos: “do inglês hard cases, a expressão identifica situações para as quais não há uma formulação simples e objetiva a ser colhida no ordenamento, sendo necessárias a atuação subjetiva do intérprete e a realização de escolhas, com eventual emprego de discricionaridade.” BARROSO, Luís Roberto e BARCELLOS, Ana Paula. “A nova interpretação constitucional: ponderação, argumentação e papel dos princípios”. In: LEITE, George Salomão (org.) Dos princípios Constitucionais. Considerações em torno das normas principiológicas da Constituição. São Paulo, Malheiros, 2003, p.116. Na literatura nacional, confira-se também STRUCHINER, Noel. "Uma análise da noção de casos difíceis do direito em um contexto positivista". In: Direito, Estado e sociedade - Revista do Departamento de Direito da PUC-Rio. n. ${ }^{\circ}$ 17, ago/dez., 2000, pp. 83-93.
} 


\section{c) O "abrandamento" da dicotomia descrição/prescrição}

Um outro elemento do enfoque pós-positivista, pedra de toque do projeto dworkiniano, situando sua obra para além do paradigma positivista, é a recusa em aceitar como axioma a distinção nuclear do positivismo - quer seja jurídico ou sociológico - entre descrição e prescrição. Dentro da proposta pós-positivista, em especial nos casos difíceis, o trabalho doutrinário procura lançar pontes entre a teoria e a prática, municiando os operadores do direito com instrumentos capazes de conduzi-los a respostas pertinentes para os problemas jurídicos, bem fundadas e ao mesmo tempo verificáveis e, na medida do possível, objetivamente controláveis. E essa controlabilidade é garantida pela argumentação jurídica, daí o papel crucial das teorias-padrão da argumentação jurídica, de Alexy e MacCormick nessa nova configuração teórica. Mais uma vez, invocando a explicação de Albert Calsamiglia quando afirma que devemos "outorgar à ciência jurídica funções não somente cognoscitivas como também reformuladoras do direito."22 Ao sustentar que a teoria não só descreve, mas também forma parte do direito, o jusfilósofo de Barcelona salienta que o pensamento jurídico tem a função de reduzir a incerteza do direito; para ele, novamente seguindo Dworkin, afirma "[que ele] considera que toda teoria jurídica deve ter um aspecto descritivo e outro aspecto prescritivo. A teoria não somente serve para conhecer o direito vigente como também é um auxiliar indispensável para o juiz. Dworkin destrói o suposto metodológico positivista da separação absoluta entre a descrição e a prescrição. Em um caso difícil a teoria é o fundamento da validade da tese da resposta correta. Sem uma teoria do direito não é possível solucionar os casos difíceis. O juiz ao utilizar a teoria como critério para a resolução aplica o direito. A teoria não somente descreve como também forma parte do direito." 23

Em relação a essa problemática, é oportuno trazer à colação uma outra passagem onde Calsamiglia destaca esse aspecto de que os juristas precisam de teorias prescritivas para resolver casos difíceis. Saliente-se que tal passagem se encontra em desafio a uma das premissas básicas do empreendimento jusfilosófico central do positivismo jurídico, A teoria pura do direito:

Penso que os juristas estão preocupados não só em ter ferramentas para identificar o direito, mas também com o desenvolvimento de uma teoria que promete respostas certas aos problemas que eles encontram. O problema que juristas normalmente têm que encarar não é com o que a norma se parece, mas o que ela tem que fazer. Juristas precisam de teorias prescritivas para resolver problemas constitucionais, isto é, casos difíceis. Kelsen pode não ser muito útil aqui, para a questão que sempre aparece no seu quadro de referências: Por que estamos nos propondo mover de uma descrição para uma prescrição? Nós deveríamos explicar a normatividade do direito. $\mathrm{E}$, para a perspectiva kelseniana isto não é um problema que a ciência possa resolver. A teoria pura do direito é uma ferramenta teorética que é útil, embora inadequada para resolver problemas práticos. Quando um autor é retirado de

\footnotetext{
${ }^{22}$ CALSAMIGLIA, Albert. “Ciencia Jurídica”. In: VALDÉS, Ernesto Garzón; LAPORTA, Francisco J. (org.). El derecho y la justicia. Madrid, Editorial Trotta/Consejo Superior de Investigaciones Científicas, 2000, p.21. Nesse mesmo texto, o jusfilósofo de Barcelona destaca dois outros traços distintivos da perspectiva póspositivista: "Os pós-positivistas não se colocam a questão de como é o direito, entendido este como um produto acabado que têm que descrever, e sim sugerem que o problema importante é como se deve decidir, para o qual é necessária uma visão racional que ofereça respostas aos interrogantes do usuário. O jurista tem algum aparelho conceitual que permita resolver o problema?" (p. 23). "Nas doutrinas pós-positivistas se dedica muita atenção à crítica do dogma da separação entre a ciência da legislação e a jurisprudência, tal qual Austin o sugeriu." (p. 24).

${ }^{23}$ CASAMIGLIA, A. "Ensayo sobre Dworkin", op. cit., p. 16.
} 
contexto, ele é muito frequentemente mal interpretado. Sem dúvida Kelsen foi mal interpretado. 24

jurídico

d) A busca de um lugar teórico para além do jusnaturalismo e do positivismo

Mais uma vez, a posição de Dworkin é emblemática daquilo que se entende por uma proposta justeorética que se situa para além dos cânones do positivismo jurídico. Embora, sua posição, por vezes, equivocadamente, seja caracterizada como um retorno ao jusnaturalismo - principalmente quando se observam as contundentes críticas do autor ao positivismo e a ênfase que o autor dá à centralidade dos direitos fundamentais e princípios suprapositivos. $^{25}$-, esse ponto de vista pode ser afastado. Isto se dá quando se observa que o jusfilósofo estadunidense, na justificação dos princípios e direitos fundamentais, não lança mão de construções metafísicas, ou as fundamenta na crença na existência de uma moral objetiva. $\mathrm{O}$ autor toma por base o construtivismo rawlsiano e, através de uma reconstrução teórica, emprega a noção de equilíbrio reflexivo como uma forma de relacionar nossas intuições morais em um conjunto articulado de proposições que poderiam integrar nossas teses em um todo coerente, dando-lhes sentido e racionalidade. Tais intuições - como as ideias de liberdade e igualdade - encontram-se formuladas nos princípios fundamentais que dão base às instituições concretamente vigentes no mundo ocidental. Em seu ensaio sobre Dworkin, Calsamiglia esclarece esse ponto de vista. Segundo ele, Dworkin não é um autor "jusnaturalista porque não acredita na existência de um direito natural que está constituído por um conjunto de princípios unitários, universais e imutáveis. A teoria do autor americano não é uma caixa abundante de noções transcendentais que permite solucionar todos os problemas e que fundamenta sua validade e justiça do direito. Dworkin rejeita o modelo de pensamento típico do jusnaturalismo - que se baseia na existência de uma moral objetiva que o homem pode e deve descobrir." 26

Ainda nesse mesmo texto, Calsamiglia destaca o que é crucial para perceber os pressupostos e as implicações do ataque antipositivista formulado por Dworkin à doutrina hegemônica do positivismo analítico de origem anglo-saxônica que deitou fundas raízes nas culturas hispânica e italiana (de Hart a Raz; de Carrió a Alchourrón e Bulygin; de Bobbio a Guastini):“ $\mathrm{O}$ autor americano tenta construir uma terceira via - entre o jusnaturalismo e o positivismo - fundamentada no modelo reconstrutivo de Rawls. Parte-se do pressuposto de que o pensamento moral se caracteriza pela construção de um conjunto consistente de princípios que justificam e dão sentido a nossas intuições." ${ }^{, 27}$ Assim, Dworkin tem uma ancoragem filosófica que se situa além dos pressupostos naturalistas de todas as doutrinas positivistas (o mesmo ocorre em Alexy, vis-à-vis Apel/Habermas)

\footnotetext{
${ }^{24}$ CALSAMIGLIA, Albert. "For Kelsen". In: Ratio Juris, vol. 13, n. 2, junho 2000, p. 213.

${ }^{25}$ Cf. sobre esse aspecto, SCRUTON, Roger. Thinkers of new left. Londres, Longman, 1985, p. 24.

${ }^{26}$ CALSAMigLiA, A. "Ensayo sobre Dworkin”. Op. cit., p. 11.

${ }^{27}$ Ibidem, p. 11. 34 Ilustrativa do pensamento do autor, a seguinte citação: "É aqui onde retornam à superfície as questões que dividem positivistas e não-positivistas. Os não-positivistas salientam o fato de que os princípios políticos e morais são usados com frequência pelos tribunais para decidir casos, como evidência de que esses padrões fazem parte do direito." SOPER, Philip. Una teoría del derecho. Madrid, Centro de Estudios Constitucionales, 1993, p. 173. 35 NINO, Carlos Santiago. La validez del Derecho. Buenos Aires, Editorial Astrea, 2003, p.145
} 
Quanto a essa polêmica acerca do suposto jusnaturalismo de Dworkin, Carlos Santiago Nino, brilhante figura do pensamento latino-americano que também pode ser arrolada entre os representantes deste "movimento" de insatisfação com o positivismo jurídico, situando o seu trabalho na interface filosofia do direito/direito constitucional, enfatiza a relação entre direito e política (assim como faz outro autor próximo a ele, Philip Soper $^{34}$ ). Embora discordando de elementos da ofensiva anti-positivista lançada por Ronald Dworkin, afirma Nino que "a controvérsia 'positivismo vs. jusnaturalismo' é quase completamente trivial e pode ser facilmente superada." $35 \mathrm{O}$ autor argentino procura salientar que tanto os jusnaturalistas, ao priorizarem excessivamente a influência da moral sobre o direito, quanto os positivistas, ao negligenciarem tal influência, são incapazes de compreender a real natureza do direito, sobretudo do direito público, nas democracias contemporâneas ${ }^{28}$.

e) O papel dos princípios na resolução dos casos difíceis

Ainda sobre Dworkin, tem-se, acerca da teoria jurídica a partir dos pressupostos não positivistas, o seguinte:

\begin{abstract}
Dworkin refuta igualmente a teoria dos casos difíceis de Hart. Os positivistas definem os casos difíceis como situações de não direito, nas quais os textos em vigor não estabelecem regras. Essa análise se apóia sobre uma concepção estreita da ordem jurídica, reduzida à soma de fontes formais do direito. Ora, explica Dworkin, um sistema jurídico não se compõe apenas de regras pontuais, que impõem em condições precisas tal ou qual comportamento. Ele repousa, antes de tudo, sobre um conjunto de princípios que podem ser enunciados na Constituição (por exemplo, o princípio da igualdade em face da lei), ou podem ser extraídos progressivamente pela jurisprudência sob a forma de princípios gerais do direito (por exemplo, o princípio de continuidade do serviço público). Contrariamente às regras que se aplicam ou não ao caso enfocado segundo a lei do tudo ou nada, os princípios possuem, uma esfera de influência ao mesmo tempo mais larga e mais difusa e uma 'força de gravidade' de natureza tal que faz pender a balança judiciária mais no sentido de uma solução do que de outra. $^{29}$
\end{abstract}

Mais uma vez, cabe destacar que tais considerações fazem sentido basicamente em relação aos casos difíceis. Como sublinham Frydman e Haarscher, o caso difícil representa para Dworkin "não um caso limite, mas, contrariamente, um caso charneira (pivotal case). Ele suscita uma compreensão da natureza profunda das regras à luz dos princípios que as sustentam. Ele constrange o juiz a reinterpretar a soma de leis e precedentes como os produtos de uma ordem justa repousando sobre um conjunto coerente de princípios". ${ }^{30} \mathrm{Na}$ continuação dessa passagem, os jusfilósofos belgas ilustram os pontos de vista centrais da perspectiva dworkiniana por meio do resumo do famoso caso Riggs v.

\footnotetext{
${ }^{28}$ Importa observar, como aponta Figueroa, que "alguns autores consideram a incorporação de certos valores morais da modernidade às Constituições como uma prova de que a razão prática se estendeu ao direito. Representariam uma prova de que, como diz Habermas, a razão prática 'emigrou ao direito' ou em palavras de Nino que a racionalidade prática teria um 'caráter imperialista' que teria permitido sua extensão sobre o direito.” In: FIGUEROA, Alfonso Garcia. Principios y positivismo jurídico, op. cit., p. 65.

${ }^{29}$ FRYDMAN, Benoit e HAARSCHER, Guy. Philosophie du Droit. Paris, Dalloz, 2002, p.93.

${ }^{30}$ Ibidem, p. 93. Livro admirável: além de sua interessante perspectiva interdisciplinar e intercultural, apresenta uma capacidade de síntese raríssima na literatura jurídica.
} 
Palmer, ponto nevrálgico da argumentação no texto seminal "Is Law a System of Rules?". No caso Riggs v. Palmer, os juízes decidiram ao arrepio dos cânones do positivismo jurídico, invocando princípios gerais do direito. Destaca-se o comentário de Dworkin acerca desse caso, onde assevera que "a corte afirmou 'todas as leis, assim como todos os contratos podem (may) ser controlados em sua operação e seu efeito pelas máximas gerais e fundamentais da common law. A ninguém pode ser permitido lucrar com sua própria fraude, ou obter vantagem do seu próprio erro, ou estribar qualquer pretensão judicial sobre sua própria iniquidade, ou adquirir propriedade em virtude de crime cometido'." ${ }^{31}$ Em relação aos belgas, saliente-se um aspecto interessante: tal cultura jurídica parece funcionar como uma espécie de encruzilhada do debate teórico contemporâneo. Dito de outra forma, embora situados na tradição romano-germânica, encontram-se muito próximos do debate angloamericano $^{32}$. Ademais, acompanham atentamente o debate para além do Reno - algo não tão habitual entre os seus vizinhos franceses (sendo assim, parece ser um ponto de vista bem interessante para observadores periféricos como nós, no horizonte jurídico brasileiro):

Tomemos, seguindo Dworkin, o exemplo do caso Elmer condenado em Nova York no fim do século XIX a uma pena de prisão por ter envenenado o seu avô. Elmer sabia que seu avô tinha feito um testamento em seu favor, legando-lhe todos os seus bens, mas acreditava que ele não tinha modificado seu testamento após um casamento tardio. Os filhos da vítima reivindicaram a sucessão, sustentando que o assassino não podia herdar. O advogado de Elmer alegou que a lei dos testamentos não previa qualquer exceção desse tipo e que o testamento deveria, por consequência, ser mantido. Os juízes, na sua maioria, não deram razão a Elmer, que, assim, não herdou do seu avô. Neste caso as regras legais positivas eram mudas. Na opinião dos juízes, para afastar Elmer de seu direito sucessório, se referiram a intenção do legislador conforme a doutrina da exegese. Mas essa justificação parece artificial, já que o legislador histórico não tinha absolutamente previsto esse caso específico. Deve-se concluir que a decisão resolveu de maneira discricionária e arbitrária um caso limite? Não, segundo Dworkin, que mostra como os juizes se apoiaram no caso em tela sobre os princípios para completar o sistema incompleto de regras legais. Eles puderam, por um lado, inferir de um grande número de precedentes que em direito não se admite que alguém tire proveito de sua má ação e, por outro, constatar que o regime de sucessões testamentárias supõe uma certa afinidade entre testador e seu herdeiro, incompatível com o crime perpetrado. $^{41}$

\section{$* * *$}

Por fim, essa nova conjuntura teórica que propiciou o surgimento de uma proposta para além do positivismo jurídico está enraizada nas condições surgidas nas últimas décadas através da dinamização dos regimes democráticos, sobretudo os europeus, redesenhando o papel do direito nas sociedades contemporâneas e, ipso facto, a atuação dos juristas, principalmente a partir do reconhecimento de uma crise do modelo liberal de democracia e do correlato papel atribuído ao cientista do direito. Mais uma vez, como observa

\footnotetext{
${ }^{31}$ DWORKIN, Ronald. In: DWORKIN, Ronald (ed.). “Is Law a System of Rules?” In: The Philosophy of Law. Oxford, Oxford University Press, 1986, p. 44.

${ }^{32}$ Como exemplo de interpenetração de culturas jurídicas no debate belga, observem-se as convergências entre a "nova retórica" de Perelman - de inspiração aristotélica - e o realismo americano de Karl Llewellyn matizado pelo empuxo normativista de Lon Füller. Outro exemplo contemporâneo é o enfoque jusfilosófico defendido por André Berten e Jacques Lenoble, ancorado em estreito diálogo com a teoria discursiva do direito de Habermas, mas se diferenciando desta pela influência recebida dos debates de filosofia da linguagem anglo-
} 


\section{Quaestio Iuris}

Calsamiglia: "a crise do Estado de direito responde à crise de ideais tais como a igualdade formal, a certeza jurídica, o formalismo jurídico, a doutrina da divisão de poderes e a da separação de direito e moral. Sob esta nova situação, o estado social não exige uma mera ausência de arbitrariedade, e sim uma adequação às necessidades da vida e à moralidade. Isto requer do aplicador do direito uma atitude mais ativa, dito de outro modo, que se inspire em uma 'ideologia dinâmica' e não meramente ' estática' da interpretação". ${ }^{2}$

Salta aos olhos, também, que esta proposta teórica - a par das condições jurídicopolíticas nas quais ela se enraíza (como as supra destacadas a partir do magistério de Calsamiglia) pode ensejar uma percepção acerca da ordem jurídica capaz de mobilizar a atenção daqueles comprometidos com o uso "transformador" do direito. A possibilidade de encarar os instrumentos legais, à luz da configuração teórica pós-positivista, como elementos capacitadores do uso emancipatório de vários institutos jurídicos vem sendo reconhecida entre nós desde sua caracterização inicial por Paulo Bonavides - jurista de inequívoco compromisso progressista. Em trabalho recente, são destacados os potenciais emancipatórios que essa abordagem acarreta. Como afirmam Luís Roberto Barroso e Ana Paula de Barcellos, “'Pós-Positivismo' é a designação provisória e genérica de um ideário difuso, no qual se incluem o resgate dos valores, a distinção qualitativa entre princípios e regras, a centralidade dos direitos fundamentais e a reaproximação entre o direito e a ética. A estes elementos devem-se agregar, em um país como o Brasil, uma perspectiva do direito que permita a superação da ideologia da desigualdade e a incorporação à cidadania na parcela da população deixada à margem da civilização e do consumo. É preciso transpor a fronteira da reflexão filosófica, ingressar na prática jurisprudencial e produzir efeitos positivos sobre a realidade". ${ }^{33}$

\footnotetext{
${ }^{33}$ BARROSO, Luís Roberto e BARCELLOS, Ana Paula. "A nova interpretação constitucional: ponderação, argumentação e papel dos princípios”.op. cit., p. 134.
} 
Intermezzo: Razão prática e argumentação jurídica

Argumentar constitui, em definitivo, a atividade central dos juristas e pode-se dizer, inclusive, que há poucas profissões se é que há alguma - em que a argumentação desempenha um papel mais importante que no direito.
A filosofia deve optar sempre pelo não existente; ela deve se engajar contrafaticamente, ela deve desafiar a realidade enquanto a reconhece.

Manfred Frank

\section{Manuel Atienza}

O que distingue radicalmente neoconstitucionalistas de positivistas é o reconhecimento da credibilidade de uma proposta contemporânea, pós-metafísica, de reabilitação da racionalidade prática. Enquanto os primeiros sustentam a superação do positivismo jurídico no novo quadro filosófico que tem raízes nas transformações no campo da filosofia moral (iniciados nos anos 70 com Rawls e Habermas), os segundos continuam aferrados ao posicionamento típico da primeira metade da última centúria infenso à ideia de que a racionalidade humana possa funcionar - além do campo das ciências da natureza - no domínio dos negócios humanos.

O quadro descrito na primeira parte deste artigo, vertebrado na obra de Albert Calsamiglia, pode ser entendido como ensejando uma posição que hoje se caracteriza como positivismo inclusivo - como a de Jose Juan Moreso, seu sucessor em Barcelona. Os positivistas inclusivos podem, ao aceitar o argumento de uma modificação significativa do direito europeu continental a partir da inclusão dos princípios jurídicos nos textos constitucionais contemporâneos, subsumir essas transformações a sua grade teórica. Tal se dá a partir da ideia de que esta posição é compatível com a inclusão através da regra de reconhecimento hartiana dos princípios de natureza moral nos sistemas jurídicos positivos. Esclareça-se que nesse caso continua-se a defender a ideia de que a relação entre direito e moral é contingente. Esta abordagem é diferente da posição - neoconstitucionalista - que defende uma relação não contingente, i. e., necessária entre direito e moral. (na forma, por exemplo, de uma complementaridade tensional, entre estas esferas normativas, através do reconhecimento do entrelaçamento e entre direito, moral e política, como diagnosticado pela teoria discursiva do direito e da democracia de Habermas e Alexy). Ademais, o neoconstitucionalismo não positivista, que tem sua matriz em Alexy, sustenta também a relação necessária entre direito e moral através da noção de pretensão de correção (quanto a este elemento central da abordagem da teoria discursiva do direito e da democracia, confira as considerações expendidas sobre Habermas no texto sobre argumentação que segue neste Intermezzo).

Os inúmeros qualificativos que o positivismo foi sofrendo ao longo da última década - inclusive o pós-positivismo sustentado por Calsamiglia - serão objeto de consideração na próxima parte deste trabalho. Importa observar que a posição de Calsamiglia se aproxima daquela adotada pelos seguidores de Hart a partir da resposta formulada por ele às criticas de 
Dworkin no pósfácio da $2^{\mathrm{a}}$ edição do Conceito de direito, conforme já mencionado na primeira parte deste trabalho. Como apresenta Figueroa "Este "novo positivismo jurídico" corresponde a várias etiquetas: "positivismo débil", positivismo inclusivo ou includente, ou "incorporativismo" [Como, por exemplo, o professor de Yale, J. L. Coleman e o jusfilósofo canadense, W. Walluchov]." 34 Tal posicionamento se alinha ao denominado positivismo inclusivo (como será salientado a seguir é compatível com uma versão de neoconstitucionalismo apresentada no livro Neoconstitucionalismo(s) organizado por Miguel Carbonell, que será o alvo de análise a seguir deste intermezzo.

Não posso tratar a contento, neste momento, o intrincado debate contemporâneo acerca das diferentes versões do positivismo jurídico surgidas após o amadurecimento da obra de Dworkin. Na literatura nacional confira a exposição panorâmica realizada por Écio Ramos Duarte no livro Neoconstitucionalismo e positivismo jurídico: as faces da teoria do direito em tempos de interpretação moral da Constituição. (São Paulo, Landy Editora, 2006), nas páginas 29 até 54; saliento a nota 40 da página 30 que apresenta uma bibliografia seminal do debate, de matriz anglo-saxônica, que tem como epicentro, como já mencionado, as respostas de Herbert Hart às críticas de Dworkin no pósfacio, da $2^{\circ}$ edição, de 1994, do livro O conceito de direito. Quanto à problemática, confira também - já situando esta discussão no contexto do direito continental, em especial no crescente debate jurídico hispano-italiano contemporâneo - a longa nota 63 (páginas 183 e 184), do texto "La teoria del derecho en tiempos de constitucionalismo" de Alfonso Garcia Figueroa, no já mencionado Neoconstitucionalismo(s). Como explica Alexy, acerca destas vertentes do pensamento jurídico contemporâneo, o positivismo inclusivo e exclusivo:

Dentro do positivismo, a distinção entre o positivismo exclusivo e inclusivo é a divisão mais importante na qual está implicada a relação entre o direito e a moral. $\mathrm{O}$ positivismo exclusivo, na forma em que o defende proeminentemente Joseph Raz, mantém que a moral está necessariamente excluída do conceito de direito. (...) O positivismo exclusivo se situa em uma relação de contrariedade com o não-positivismo, que sustenta estar a moral necessariamente incluída no conceito de direito, vale dizer que está necessariamente não excluída do mesmo. O positivismo inclusivo, tal como o defende, por exemplo, Jules Coleman, pode considerar-se como uma rejeição tanto do positivismo exclusivo como do não-positivismo. O positivismo inclusivo assinala que a moral não está necessariamente excluída nem necessariamente incluída. Declara que a inclusão é contingente ou um assunto convencional (...) que depende do que em realidade estabeleça o direito positivo. $\mathrm{O}$ nãopositivismo, ao sustentar não somente que a moral não está necessariamente excluída senão que está necessariamente incluída, é contrário a ambas formas de positivismo. ${ }^{45}$

É a partir das obras de Habermas e Alexy que inequivocamente se abre as possibilidades do novo paradigma jurídico, o neoconstitucionalismo. Alexy, no texto programático de $1981^{35}$, escrito em colaboração com Aulis Aarnio e Alexander Peczenick

\footnotetext{
${ }^{34}$ FIGUEROA, Alfonso G. "Princípios e direitos fundamentais" In: SOUZA NETO, Cláudio Pereira e SARMENTO, Daniel. A constitucionalização do direito: fundamentos teóricos e aplicações específicas. Rio de Janeiro, Lumen Juris, 2007, p. 8. 45

ALEXY, Robert. "En torno al concepto y la naturaleza del Derecho" In: El concepto y la naturaleza del Derecho. Madrid, 2008, pp. 80 e 81.

${ }^{35}$ Tais desenvolvimentos podem ser consultados no texto "The Foundation of Legal Reasoning” In: Rechtstheorie 12 (1981), Dunker \& Humbolt, Berlim. Utilizei o excerto publicado em francês na coletânea Le positivisme juridique, op. cit. A referência completa da publicação original deste texto: AARNIO, Aulis; ALEXY, Robert; PECZENIK, Aleksander, “The Foundation of Legal Reasoning” In: Rechtstheorie, num. 12 , 1981, pág. 133-158, 257-279 y 423-448.
} 
destaca que essa nova configuração do panorama jurídico desenvolvido nas últimas décadas, insatisfeita com o quadro teórico positivista, está alicerçada em uma mudança mais geral no quadro da filosofia contemporânea. Como sintetizam os três nomes centrais deste enfoque, quatro ideias descrevem essa nova configuração filosófica - condição de possibilidade de uma concepção que se posiciona para além do positivismo no campo jurídico: (i) reabilitação da razão prática, (ii) enfraquecimento da oposição entre a corrente hermenêutica e a corrente analítica da filosofia, conduzindo ao conceito de uma hermenêutica analítica, (iii) inclusão de aspectos sociológicos e históricos nas considerações de teoria da ciência, (iv) aproximação entre a filosofia analítica e a teoria crítica do direito. Tais mudanças, somadas aos esforços desses três notáveis jusfilósofos, têm permitido a proposta de uma teoria jurídica global ou integral, em que se procura evitar as posições unilateralizantes, como, por exemplo, a normativista, que focaliza como centro da vida jurídica a norma; as diversas correntes sociológicas, atentas, basicamente, à dimensão social do fenômeno jurídico e as concepções de inspiração jusnaturalista acentuando excessivamente a esfera valorativa na compreensão da experiência do direito.

Quanto à reabilitação da razão prática operada pela teoria discursiva do direito e da democracia, em mais de 100 páginas - no livro já citado, Jürgen Habermas: filósofo do direito, - estão apresentadas características da arquitetônica filosófica habermasiana capitais à sua empreitada de reabilitação da razão prática: e.g., os traços mais gerais de uma ética cognitivista de inspiração kantiana, o papel desempenhado pela ideia de ciência social reconstrutiva, a teoria da evolução moral habermasiana, a posição da teoria do discurso vis à vis o debate liberais vs. comunitaristas e o conceito de mundo da vida. Saliento que este livro apresenta como tese central a exposição de elementos teóricos mobilizados por Habermas capazes de respaldar uma proposta jusfilosófica que se situa além do positivismo jurídico (saliente-se o item 2.3, Habermas/Alexy e o discurso pratico para os fins mais específicos da argumentação presente neste intermezzo). Esta argumentação está alargada no texto "Acerca dos direitos humanos e o diálogo intercultural" 36 onde é enfrentada a delicada querela acerca do ethnocentric predicament, em especial a partir das críticas de Richard Rorty em relação ao posicionamento universalista sustentado pelo herdeiro da Escola de Frankfurt no campo da filosofia moral .

A "ética do discurso" (Diskursethik) caracteriza-se por ser um enfoque cognitivista (sobre esta categoria do discurso metaético, conferir o anexo 2), isto é, que sustenta a possibilidade de justificação racional no âmbito dos negócios humanos, inspirado numa reinterpretação da intuição básica presente no imperativo categórico kantiano - um princípio de universalização - expressa numa proposta procedimentalista que realiza-se através de uma teoria da argumentação. Tal proposta procura produzir um critério baseado na ideia de imparcialidade - núcleo dos "ganhos" de aprendizagem moral alcançados pela modernidade ocidental com a transição para um estado pós-convencional de consciência moral. O nível de consciência moral pós-convencional (reconhecido a partir dos trabalhos de Piaget e Kohlberg) pressupõe a faculdade de tomar parte em discursos práticos. Neste particular, há uma confluência entre as propostas de Habermas e Robert Alexy, alicerçadas na ideia de discurso prático. Em especial, se tivermos em mente que "Alexy formalizou em regras grande parte das condições

\footnotetext{
${ }^{36}$ MAIA, Antonio Cavalcanti. “Acerca dos direitos humanos e o diálogo intercultural” In: BITTAR, Eduardo C. B. (coord.) Educação e metodologia para os direitos humanos. São Paulo, Quartier Latin, 2008.
} 
discursivas avançadas por Habermas." ${ }^{37}$ Assim, estes elementos teóricos são mobilizados por Habermas (e, no caso, também, Alexy) para elevar o debate jusfilosófico a um diferente patamar, abrindo a possibilidade de um novo momento - como o neoconstitucionalismo - na história do pensamento jurídico ocidental. Destaque-se ainda que a plausibilidade do discurso prático constitui elemento capital na chamada reabilitação da filosofia prática. A abertura dessa dimensão teórica enseja o solo a partir do qual tanto Habermas como Alexy podem oferecer a proposta de superação do estiolado debate jusnaturalismo/positivismo jurídico, com a reabertura do domínio normativo às discussões racionais, insurgindo-se contra o ceticismo dominante no quadro jusfilosófico Novecentista. Tal empreitada refuta um dos postulados das diversas correntes do positivismo - quer seja sociológica, normativa ou realista, bem como de todos os inúmeros discípulos de Wittgenstein, ao reconhecer que "o mundo da ética não é o mundo do silencio, mas dos argumentos - eis a resposta habermasiana". ${ }^{38}$ Propõem, desta forma, os autores neofrankfurtianos uma ética minimalista, capaz de apontar às condições procedimentais aos inúmeros debates públicos presentes nas sociedades pluralistas contemporâneas. Tal proposta teórica permite também uma saída tanto do objetivismo metafísico da teoria dos valores, como do ceticismo radical de correntes positivistas.

No tocante à razão prática no âmbito do direito importa destacar a obra de Chaim Perelman. Partindo da reabilitação da razão prática de matriz aristotélica Perelman erguia - até o surgimento das obras de Dworkin e Alexy - a mais contundente crítica até então formulada ao positivismo kelseniano. Se a questão da razão prática aproxima o projeto perelmaniano da ética do discurso, a utilização dos princípios gerais do direito, em sua crítica ao normativismo o aproxima de Dworkin. No texto "Notas sobre direito, argumentação e democracia" ${ }^{39}$ (do qual foram retiradas as passagens citadas no fim deste parágrafo) o posicionamento do filósofo de Bruxelas vertebra a estrutura daquela investigação (onde se abre o campo das discussões teóricas aqui expostas em relação à questão do póspositivismo). Naquela ocasião objetivou-se apresentar as críticas metodológicas dirigidas às insuficiências do positivismo jurídico. Com efeito, Perelman (e a lista de autores por ele exposta, arrolada na nota infra), elaboraram reprovações ao paradigma jurídico dominante na primeira metade da centúria passada que se caracterizavam "pelo fato de que, constituem todos eles uma reação contra o positivismo jurídico, e não se fundam em nenhuma ideologia prévia, somente numa análise do raciocínio judicial e de uma reflexão essencialmente metodológica". ${ }^{40}$ Então, naquele momento (1999) ainda não era tópico de discussão na

\footnotetext{
37 ARROYO, Juan Carlos Velasco. La teoría discursiva del derecho. Sistema jurídico y democracia em Habermas. Madrid, Centro de Estudos Políticos y Constitucionales, 2000, p. 126.
}

${ }^{38}$ MILOVIC, Miroslav. Comunidade da diferença. Rio de Janeiro, Relume Dumará; Ijuí, Unijuí, 2004, p. 58.

${ }^{39}$ MAIA, Antonio Cavalcanti. "Notas sobre direito, argumentação e democracia". In: CAMARGO, Margarida Maria Lacombe (org.). 1988 - 1998: Uma década de Constituição. Rio de Janeiro, Renovar, 1999.

${ }^{40}$ Oportuno também observar o rol de autores apontados por Perelman que situam suas empresas teóricas para além dos estritos limites do positivismo jurídico: "Os esforços do professor Esser (Grundsatz und Norm in der richterlichen Fortbildung des Privatrechtes, 1954) tem sido continuados na Alemanha, sobretudo pelos professores Martins Kriele (Theorie der Rechtsgewinnung, 1967) e Othmar Ballweg (Rechtwissenschaft und Jurisprudenz, 1970), na Holanda pelo professor Ter Heide (Jude viator: Probleem of systeemdenken of gesystematiseerd probleemdenken, Ars aequi, 1967), na Bélgica pelo professor W. van Gerven (Het beleid van de rechter, 1973), no México pelo jurista espanhol L. Recasens Siches (Nueva filosofia de la interpretación del derecho, 1956). Estas obras se aliam às análises de juristas angloamericanos, como K.N. Lewellyn ( The Common Law Tradition, Deciding Appeals, 1960), R. M. Dworkin (“The Model of Rules", 1967, publicado em Law,Reason and Justice, 1969, pp. 3-43), E. Bodenheimer (Jurisprudence, 1974, 2 ed.) e os trabalhos de J. 
literatura jurídica nacional a problemática do pós-positivismo. Um dos objetivos do texto foi aproximar Perelman desta categoria, a qual desde o trabalho de Paulo Bonavides, já subsumia as empresas justeoréticas, insatisfeitas com o paradigma juspositivista. Peço licença para arrolar aqui duas passagens daquele trabalho:

Importa ressaltar um aspecto relevante das consequências trazidas por tal abordagem privilegiadora do enfoque argumentativo no campo da filosofia do direito. Boa parte desses trabalhos vieram contribuir para a erosão do paradigma positivista hegemônico ate os anos setenta. Em relação à perene disputa nos arraiais jusfilosóficos: jusnaturalismo/positivismo jurídico, estes autores vieram a se colocar num lugar diferente, propondo uma crítica metodológica ao positivismo jurídico. (...)Esta intenção de situar o seu trabalho alem dos dois posicionamentos tradicionais do debate jusfilosófico é claramente exemplificada pelo próprio título de um de seus últimos livros de filosofia do direito: Le raisonnable et le déraisonnable em droit. Au-delà du positivisme juridique, de 1984. Assim, Perelman se coloca como um dos nomes centrais do paradigma já denominado de pós-positivista, tendo como corifeus, também, R. Alexy e R. Dworkin".

\title{
E na conclusão deste mesmo artigo:
}

\begin{abstract}
Em primeiro lugar, pode-se sustentar que o movimento geral de ideias jusfilosóficas das últimas décadas assinala um enfraquecimento da hegemonia da perspectiva positivista. Como já salientado, no campo da metodologia jurídica, as críticas formuladas por Perelman e outros autores próximos de sua démarche contribuíram para o desgaste de alguns dos pontos de vista defendidos pelas correntes jurídicas de inspiração kelseniana (ou na mais atual versão do positivismo de Niklas Luhmann). Assim, também a filosofia do direito conheceu, em especial nos Estados Unidos e na Alemanha, algo como uma revitalização, através principalmente das críticas desenvolvidas por Ronald Dworkin, Jürgen Habermas e Robert Alexy ao positivismo jurídico.
\end{abstract}

Quanto aos princípios jurídicos, em texto escrito em coautoria com Cláudio Pereira de Souza Neto, expusemos parte do posicionamento de Perelman ${ }^{41}$, em especial elencandoo, juntamente, com Dworkin e Alexy como os protagonistas da virada dos estudos jusfilosófios em direção ao que agora em meados do século XXI descrevemos como paradigma neoconstitucionalista. É claro que no caso de Perelman não se está trabalhando tanto no campo do direito constitucional como no dos dois autores referência do póspositivismo e/ou neoconstitucionalismo - uso indistintamente os termos nesse momento denotando o seguinte: I - o pós-positivismo pode ser compreendido como quadro teórico dominante dos anos 90 face "o caráter devastador do argumento dos princípios contra a concepção positivista" "42; II -

Stone (Human Law and Human Justice, 1964, e Legal Systen and Lawyer's Reasoning, 1964). Na França, os trabalhos de L. Husson (Les transformations de la responsabilité, 1947, e Nouvelles études sur la pensée juridique, 1974) se orientam claramente no mesmo sentido.” In: PERELMAN, Chaïm. Logique juridique. Nouvelle rhétorique. Paris, Dalloz, 1979, p. 81-82.

${ }^{41}$ Cf. MAIA, Antonio Cavalcanti e SOUZA NETO, Cláudio Pereira de. "Os princípios de direito e as perspectivas de Perelman, Dworkin e Alexy” In: PEIXINHO, Manoel Messias et al (org.). Os princípios da Constituição de 1988. Rio de Janeiro, Lumen Juris, 2001. Sobre as relações de Perelman com a teoria discursiva do direito, veja-se, por exemplo, o texto: TOMAS, Gil. "La diskursethik et la théorie de l'argumentation de Ch. Perelman deux conceptions différentes de la rationalité pratique". In: Chaïm Perelman et la pensée contemporaine. Bruxelas, Bruylant, 1993. Para uma excelente apresentação da empresa justeorética do filósofo de Bruxelas veja-se: MANASSERO, Maria de los Ángeles. De la argumentación al derecho razonable. Um estúdio sobre Chaïm Perelman. Navarra, Eunsa, 2001.

${ }^{42}$ FIGUEROA, Alfonso G. "Princípios e direitos fundamentais" In: SOUZA NETO, Cláudio Pereira e SARMENTO, Daniel. opus cit., p.21. 
o que se convencionou denominar pós-positivismo na literatura constitucionalista brasileira (cujo esboço de cartografia foi exposto na primeira parte deste trabalho) avança em direção a uma posição neoconstitucionalista.

Com efeito, acredito que dois constitucionalistas representam esta mudança de atitude no pensamento jurídico brasileiro: Luís Roberto Barroso e Lenio Streck. Quanto ao primeiro, a publicação, em 2008, de seu texto Neoconstitucionalismo e la constitucionalización do Derecho, no México, bem como o próprio título de seu Curso de direito constitucional contemporâneo - os conceitos fundamentais e a construção do novo modelo, sinaliza nessa direção (sobretudo no capítulo IV - Novos paradigmas e categorias da interpretação constitucional); quanto ao segundo, a sua já tradicional crítica ao positivismo jurídico através do viés hermenêutico-filosófico se encontrou recentemente com a adoção de uma posição em diálogo com a filosofia jurídica dworkiniana, como, por exemplo, nos textos: "A resposta hermenêutica à discricionariedade positivista em tempos de pós-positivismo"54 e "A crise paradigmática do direito no contexto da resistência positivista ao (neo)constitucionalismo"55

É da lavra de Luís Roberto Barroso um ilustrativo enquadramento da problemática concernindo às relações entre neoconstitucionalismo e pós-positivismo:

Em suma: o Neoconstitucionalismo (...) identifica um conjunto amplo de transformações ocorridas no Estado e no direito constitucional, em meio às quais podem ser assinalados, (i) como marco histórico, a formação do Estado constitucional de direito, cuja consolidação se deu ao longo das décadas finais do século XX; (ii) como marco filosófico, o pós-positivismo, com a centralidade dos direitos fundamentais e a reaproximação entre Direito e ética; e (iii) como marco teórico, o conjunto de mudanças que incluem a força normativa da Constituição, a expansão da jurisdição constitucional e o desenvolvimento de uma nova dogmática da interpretação constitucional. Desse conjunto de fenômenos resultou um processo extenso e profundo de constitucionalização do Direito. ${ }^{56}$

Em relação ao constitucionalista brasileiro, Miguel Carbonell aponta um aspecto marcante, que subjaz ao enfoque dos juristas neoconstitucionalistas em nosso país, ao afirmar Barroso, "adota como chave metodológica pontos de vista novos, progressistas. Sempre parece caminhar à frente de seu tempo, ensinando-nos a senda do que o direito será nos próximos anos, nas seguintes décadas." ${ }^{\circ 7}$ Este olhar voltado para o futuro em um país marcado por uma "pulsão futurante", anima aqueles comprometidos com um novo paradigma jurídico integrador como o neoconstitucionalismo. Acredito, também que o grande interesse despertado entre os constitucionalistas brasileiros sobre este debate, originariamente jusfilosófico - acerca da mudança paradigmática, em direção ao póspositivismo e ao neoconstitucionalismo - deveu-se, por um lado, ao interesse de muitos dos protagonistas no nosso debate constitucional pelas ideias jusfilosóficas e, por outro, à constatação da necessidade imperiosa da criação de uma doutrina capaz de operacionalizar os conteúdos emancipatórios dos direitos fundamentais através da construção de uma metodologia balizadora da aplicação do generoso elenco de garantias e direitos de nossa Lei Maior, em especial enfrentando a tormentosa problemática da justiciabilidade dos direitos sociais. Afinal, quando Robert Alexy esteve pela primeira vez em nosso país, concluiu sua conferência no Rio de Janeiro apontando para a pertinência da utilização de sua teoria em relação a uma das questões mais tormentosas enfrentadas pela dogmática constitucional brasileira:

Para uma Constituição como a brasileira, que formulou tantos princípios sociais generosos, surge, com base nesse fundamento, uma pressão forte para, desde logo, se dizer 


\begin{abstract}
que as normas que não possam ser aplicáveis sejam declaradas como não vinculantes, isto é, como simples normas programáticas. A Teoria dos Princípios pode levar a sério a Constituição sem exigir o impossível. Ela pode declarar que normas não executáveis são princípios que, em face de outros princípios, hão de passar pelo processo de ponderação. E
\end{abstract}

Parágrafo único: as diferenças entre pós-positivismo na doutrina brasileira e na doutrina europeia - Habermas ${ }^{43}$ e Atienza e a Escola de Alicante. ${ }^{44}$

Ao longo dos últimos anos, diversos textos sobre o pós-positivismo foram publicados (além daqueles arrolados na nota 5). Não poderia aqui dar conta do que tem sido debatido em todos eles, no entanto, cabe salientar que os textos mais antigos (quase uma década de debate) avançaram na pesquisa do tema, porém ainda não encontraram o debate amadurecido. Expus na primeira parte deste texto a (desculpe se pode soar pouco modesto) a mais detalhada exposição sobre essa problemática em nossas letras jurídicas. Recentemente, dois textos de 2009 e 2011 merecem aqui a referência pela relevância e novidade que trazem para essa discussão. O texto de Rachel Nigro "A Virada linguístico-pragmática e póspositivismo" 45 obteve um equilíbrio raro em nossa literatura jusfilosófica: o correto balanceamento entre debate filosófico e discussão jurídico constitucional. Este denso trabalho complementa uma área das reflexões filosóficas que garante o solo teórico a partir do qual pode-se pensar o pós-positivismo (e o neconstitucionalismo também): o linguisticpragmatic turn da filosofia contemporânea. Nesse sentido, saliente que Rachel apresenta uma parte cardeal das relfexões filosóficas de Habermas que nunca apresentei a contento - por conhecimento insuficiente -, complementando assim a apresentação ao leitor brasileiro da arquitetônica filosófica habermasiana para uma adequada compreensão de suas análises que têm como foco principal as problemáticas do campo jurídico-constitucional.

Já o texto de Rafael Simioni traz ao debate a perspectiva - ancorada na sociologia funcional-sistêmica de Niklas Luhmann - de uma das correntes jurídicas mais prestigiosas do cenário internacional e já com sólida representatividade em nosso país. O trabalho de Rafael apresenta um bem qualificado elenco de autores pós-positivistas. Como seu ponto de vista parte da teoria dos sistemas, com o trabalho monumental de Luhmann - com sua erudição, inventividade e potencial heurístico - ele aborda as diferentes posições do póspositivismo através da ideia-chave do que cada uma delas pode oferecer como suplemento (grifo meu) à teoria sistêmica. Certamente não poderei explicar como gostaria o que afirmarei a seguir. Todo debate sobre o pós-positivismo e neoconstitucionalismo passa ao largo da teoria sistêmica. O trabalho sociológico de Luhmann alcançou tal dimensão que torna impossível para qualquer abordagem filosófica - como a da Teoria crítica da sociedade de Frankfurt que tenha pretensões de, com a colaboração das ciências sociais empreender uma análise da sociedade, negligencie suas contribuições teóricas. No entanto, essa démarche teórica

\footnotetext{
${ }^{43}$ Confira-se, por exemplo, HABERMAS, Jürgen. Postscript In: Between Facts and Norms: Contributions to a Discourse Theory of Law and Democracy. Cambridge, The MIT Press, 1996.

${ }^{44}$ Sobre a Escola de Alicante acerca desta questão do pós-positivismo, confira: ATIENZA, Manuel. "Es el positivismo jurídico uma teoria aceptable del derecho?” In: MOREIRA, Eduardo Ribeiro; PUGLIESI, Marcio (coord.). 20 anos da constituição brasileira. São Paulo, Saraiva, 2009. E também no mesmo livro: REGLA, Josep Aguiló. “Del 'imperio de la ley' al 'estado constitucional'. Dos paradigmas jurídicos en pocas palabras”. ${ }^{45}$ NIGRO, Rachel, “A virada linguístico-pragmática e o pós-positivismo”. In: Direito, Estado e sociedade. Rio de Janeiro, Pontifícia Universidade Católica - Departamento de Direito, 2009
} 
conseguiu obter grande sucesso nas décadas de 70, 80 e 90 no âmbito da sociologia jurídica (ça va sans dire!) e, no campo do direito privado com o trabalho emblemático de Teubner. A teoria sistêmica ${ }^{46}$, data venia, por um lado, por conta de seus postulados sociológicos encampando como axioma a distinção ontológica entre ser/deverser e o hiato entre fatos e valores - e, por outro, pela própria proposta teórica que encampa (com o objeto de estudo e investigação que opta por trabalhar) não tem condições de dar conta da dimensão axiológica e da natureza política do direito constitucional contemporâneo. Sendo assim, toda essa vasta literatura internacional que trata do póspositivismo e neoconstitucionalismo não trata das posições positivistas sistêmicofuncionalistas.

Essa discussão merecerá melhor tratamento em futuras apresentações desta pesquisa, arrolo agora aqui o interessante elenco apontado por Rafael Simioni, entre outras coisas por incluir um autor brasileiro e um português. Embora toda discussão do direito constitucional brasileiro a partir de um enfoque principialista seja devedor do magistério de José Gomes Canotilho, não ocupa, no debate jurídico português, posição de destaque às referências à discussão acerca do pós-positivismo e do neoconstitucionalismo. Saliento que neste elenco não consigo compreender que critérios foram utilizados para subsumir Richard Posner a uma categoria que inclui Habermas, Alexy, Dworkin, Streck e Castanheira Neves!

De qualquer modo, podemos sintetizar os suplementos de cada uma das principais concepções pós-positivistas de decisão jurídica: para o procedimentalismo de Habermas (2003), o suplemento é o consenso obtido sob condições ideiais de discussão, procedimentalmente constituídas; para o procedimentalismo de Alexy (1993), os discursos prático-morais; para o substancialismo de Dworkin (1986), o suplemento está nas convicções de moralidade política da comunidade; para o substancialismo de Streck (2009), o horizonte da interpretação autêntica da Constituição constitui um sofisticado suplemento; para o pragmatismo de Posner (2008), a eficiência econômica e a reflexão sobre as consequências da decisão; para o jurisprudencialismo de Castanheira Neves (1993), o suplemento está na dialética entre a intencionalidade hermenêutica do caso concreto e os princípios substanciais suscitados por ela. ${ }^{47}$

Todavia, se no Brasil pode-se reconhecer uma tendência a utilizar intercambiavelmente os termos "pós-positivista" e "neoconstitucionalista" sem maiores problemas em termos teóricos, o mesmo não pode ser dito em face do que ocorre na cultura continental europeia. Dois dos principais autores no debate jurídico contemporâneo, Jürgen Habermas e Manuel Atienza, são indiscutivelmente pós-positivistas - construindo duas poderosas obras de desmonte do paradigma positivista - contudo não se sentiriam a vontade sob o rótulo

\footnotetext{
${ }^{46}$ Para uma aproximação desta não trivial tese aqui sustentada, remeto o leitor a texto onde a obra de Luhmann mereceu considerações a partir do ponto de vista (pós-positivista/neoconstitucionalista) adotado nesta pesquisa: MAIA, Antonio Cavalcanti. "Prefácio. O direito entre o moderno e o pós-moderno: é possível escapar da antinomia Habermas/Luhmann?" In: DINIZ, Antonio Carlos de Almeida. Teoria da legitimidade do direito e do Estado: uma abordagem moderna e pós-moderna. São Paulo, Landy Editora, 2006. Em relação, por exemplo, ao mais frutífero desenvolvimento, stricto sensu jurídico da teoria dos sistemas de Luhmann, a obra de Gunther Teubner, O direito como sistema autopoiético, Lisboa, Fundação Calouste Gulbenkian, 1989, não encontramos neste trabalho ideias interessantes a respeito do direito público. Tive a oportunidade de levantar esta questão diretamente ao jurista alemão em mesa que participamos juntos na Faculdade de Direito da Fundação Getúlio Vargas, em 2005 a convite do inesquecível Luís Fernando Schuartz. O professor alemão, figura muito cortês e simpática, não pôde responder a tal objeção.

${ }^{47}$ SIMIONI, Rafael. "O que a decisão jurídica observa? Contribuições da teoria dos sistemas de Niklas Luhmann às teorias pós-positivistas da decisão jurídica" In: SCHWARTZ, Germano (org.) Juridicização das esferas sociais e fragmentação do direito na sociedade contemporânea. Porto Alegre, Livraria do Advogado Editora, 2012, p. 101.
} 
"neoconstitucionalista". Em relação ao herdeiro da Escola de Frankfurt, pode-se singelamente destacar duas razões pelas quais ele não poderia reconhecer como neoconstitucionalista: a recusa em reconhecer a racionalidade do processo de ponderação de princípios jurídicos e o alargamento das funções do Judiciário ${ }^{64}$ reconhecido no cenário do Estado de direito constitucional pelos neoconstitucionalistas.

Sobre Atienza a situação é mais complexa, pois ele concorda com a ideia da racionalidade da ponderação e, não parece estar particularmente preocupado com o diferente papel assumido pelo Judiciário em certos países no cenário contemporâneo. O jusfilósofo de Alicante, como nenhum outro autor na cultura jurídica romano-germânica (à exceção de Alexy) personifica o novo papel do filósofo do direito - diferente da quadra histórica dominada quer seja pelo positivismo normativismo kelseniano, e de seus dois principais troncos de refinamento teórico, a fecunda relação com a filosofia analítica no positivismo italiano dos anos 70 a 90, e o impulso logicista da escola portenha de Carlos Alchourrón e Eugenio Bulygin. Quem descreve com precisão este novo quadro da filosofia do direito no qual Atienza se destaca, - e no qual vai surgir o neoconstitucionalismo - é um dos principais protagonistas do debate hispano-falantes Francisco J. Laporta destacando as enormes transformações do pensamento jurídico contemporâneo acarretadas a partir da obra de John Rawls e "um de seus mais devotos discípulos (...), Ronald Dworkin”:

\begin{abstract}
Abre-se também subitamente a filosofia do direito a todo o panorama da filosofia moral, abandonando assim a predominante atitude cética e relativista, ou simplesmente desinteressada, que havia acompanhado durante esses anos os estudos de teoria do direito. A ideia da justiça como um ideal irracional, que havia estado muito presente na teoria jurídica desde Kelsen, deixa de ser o ponto de partida. Começam a aparecer então temas perfeitamente alheios à filosofia do direito tal e como se concebia comumente. Coisas tais como a desobediência civil, o aborto ou a liberdade de expressão não haviam sido debatidos em nossas velhas faculdades. De uma filosofia do direito cujo objeto preferencial eram as regras e o sistema jurídico se passa assim a uma filosofia do direito centrada em princípios, postulados morais, direitos individuais e questões ligadas também à peripécia política dos cidadãos. De uma teoria do direito com pretensões de autonomia, de pureza no sentido kelseniano, se acaba passando assim passando assim a uma teoria do direito que se girava em direção à filosofia moral e política. ${ }^{65}$
\end{abstract}

Em torno de Manuel Atienza, em Alicante, reuniram-se jusfilósofos como Josep Aguilló Regla e Juan Ruiz Manero e seus ex-alunos como Isabel Linfante Vidal e Daniel González Lagier - representando um dos focos centrais do debate jusfilosófico contemporâneo em escala mundial (atestado também pela publicação sob a responsabilidade deste grupo da mais importante publicação do mundo ibero-americano na área de filosofia e teoria do direito: a revista DOXA). Articulando uma feliz combinação de rigor e clareza inspirado pela filosofia analítica, com a erudição histórica espanhola e a aposta na fecundidade da utilização contemporânea nas teorias da argumentação dos elementos da

64

Esta, sem dúvida, é uma questão central no tocante à aceitação ou reprovação no paradigma neoconstitucionalista. O texto mais citado ou mencionado por meus colegas constitucionalistas em face de minha defesa deste novo paradigma é o da lavra de uma colaboradora de Habermas, Ingeborg Maus: Judiciário como superego da sociedade: o papel da atividade jurisprudencial na sociedade órfã. In: Novos Estudos, CEBRAP, $\mathrm{n}^{\circ}$ 58, nov. 2000. Na conclusão deste trabalho apresento algumas considerações sobre esta problemática, - em especial, no tocante à necessidade do desenvolvimento de uma cultura argumentativa que parametrize mais rigorosamente as decisões judiciais - sem, obviamente, tentar exaurir questões de tal envergadura. Entretanto, deve-se estar atendo à afirmação de Alfonso García Figueroa de que o 
"neoconstitucionalismo impulsiona uma maior atividade judicial, mas não maior ativismo judicial." (grifo meu). In: Criaturas de la moralidad: una aproximación neoconstitucionalista al Derecho a través de los derechos. Op. Cit. p. 51. 65

FIGUEROA, Alfonso García. Racionalidad y Derecho. Madrid, Centro de Estudios Políticos y Constitucionales, 2006, p. 16.

tradição retórica greco-romana ${ }^{48}$, com um empenho político de utilização da teoria do direito que abandona uma posição "ensimesmada" para converter-se num elemento de dinamização da cultura jurídica.

Em relação à filosofia analítica, cabe sublinhar a vinculação do grupo de Alicante com a escola de filosofía jurídica finlandesa. ${ }^{49}$ Esta escola, diferentemente do realismo escandinavo - que optou por uma abordagem de análise científico-social do direito, conscientemente redutora do objeto de análise "direito", inspirado nas ciências sociais - é distinta dos seus vizinhos suecos. Em primeiro lugar, os professores das faculdades finlandesas de direito eram treinados na Alemanha - e assim não muito inclinados aos excessos empiristas da Escola de Uppsala. Em segundo lugar, a influência da filosofia anglosaxônica de matriz wittgensteiniana é avassaladora neste pequeno país. Georg Henrik von Wright que "possui o amável encanto de um espírito talhado ao modo da velha Europa, civilizado e com o espírito cívico da Escandinávia" ${ }^{50}$ fez escola; sucessor do gênio austríaco em Cambrigde, serviu de inspiração a uma figura cimeira do pensamento jusfilosófico continental - e um dos protagonistas da mudança geral nos quadros mentais que abriram o caminho para o pós-positivismo - Aulis Aarnio. Assim, este encontro teórico contribuiu para a construção de um dos pólos mais interessantes do pensamento jurídico contemporâneo. Ademais, graças "as visitas de Georg Henrik von Wright a Argentina e que tem continuado no presente com os encontros periódicos de juristas finlandeses e espanhóis que se celebram alternadamente em Alicante e Tampere" ${ }^{\text {, }}$, impôs-se uma mudança sensível no mainstream do pensamento jusfilosófico espanhol, muito influenciado durante a ditadura franquista pelo pensamento conservador, na maior parte dos casos, de corte jusnaturalista.

Entretanto, a posição de Atienza, que se identifica existencialmente como filósofo analítico (como me revelou em conversas que tivemos no Rio nos dias 20 e 21 de novembro de 2011), é bem diferente do ceticismo moral assumido por esta corrente filosófica e por seus desdobramentos do campo jurídico, como testemunhamos no aferrado posicionamento da última escola ortodoxa positivista no mundo latino (ainda por cima defensora do positivismo exclusivo!), os analíticos argentinos. O jusfilósofo espanhol, em debate com o líder do grupo portenho (com diversas ramificações no mundo ibero-americano) Eugenio Bulygin, na principal mesa do 23 IVR Congresso Mundial, 1 a 6 de agosto de 2007, em Cracóvia, na Polônia, estabeleceu uma clivagem no pensamento jurídico, sobretudo hispanofalante, ao

\footnotetext{
${ }^{48}$ Como conclui Atienza, em uma espécie de "acabamento" teórico de sua obra, o livro El Derecho como argumentación - concepciones de la argumentación, Barcelona, Editora Ariel, 2006, p. 217. "Nos clássicos da retórica (Aristóteles, Cícero e Quintiliano) pode encontrar-se a resposta a muitos dos problemas quando alguém trata de construir uma argumentação; também (ou especialmente) em contextos jurídicos."

${ }^{49}$ Conforme a "Introdução" do livro La normatividad del Derecho, coordenado por Aulis Aarnio, Ernesto Garzón Valdés e Jyrki Uusitalo.

${ }^{50}$ HABERMAS, Jürgen. "Entre tradiciones. Una laudatio a Georg Henrik von Wright” In: Fragmentos filosófico-teológicos: De la impression sensible a la expresión simbólica. Madrid, Editorial Trotta, 1999, p. 58. Sobre o filósofo finlandês von Wright, veja-se, por exemplo, o magistral texto de Habermas "Entre tradiciones. Uma laudatio a Georg Henrik von Wright".

${ }^{51}$ AARNIO, Aulis; VALDÉS, Ernesto Garzón; UUSITALO, Jyrki. “Introducción” In: La normatividad del Derecho, Barcelona, Editorial Gedisa, 1997, p. XII.
} 
distinguir duas correntes de inspiração analítica: a primeira, já tradicional, o normativismo logicista, de Carlos Alchourrón e Bulygin e "a outra linha (na qual jogou um papel fundamental à obra de Carlos Nino) se tem caracterizado por defender teses positivistas muito mais abertas (o positivismo "inclusivo") inclusive não positivistas, por reivindicar a racionalidade da ética (o cognitivismo em condições mais ou menos fortes) e uma concepção não insular do pensamento jurídico que leva a conceber a filosofia do Direito como uma filosofia prática, ao lado (e em estreita conexão com) a filosofia moral e política." ${ }^{, 52}$

Assim, Atienza e o grupo de Alicante constituíram a mais sólida reprovação às correntes positivistas no cenário de língua espanhola e obtiveram também significativa repercussão no debate italiano (espero também no futuro próximo em nosso debate jurídico). No entanto, Atienza recusa-se a subsumir seu trabalho a rubrica do neconstitucionalismo (como ele me fez entender nas conversas que tivemos em novembro de 2011). Não poderei aqui, neste momento, expender mais considerações acerca desta divergência teórica (o que será assunto de maiores reflexões na próxima exposição desta pesquisa). Fica o registro, marcando as diferenças entre o debate continental europeu e a recepção destas ideias em nosso país. Entretanto, em face do exposto, adoto a tese de que não acarreta maiores problemas a utilização intercambiável dos termos pós-positivista e neoconstitucionalista em nosso país, na medida em que podemos assistir a uma transição daqueles juristas que se sentiam melhor representados pela categoria pós-positivista em direção ao neoconstitucionalismo.

Sobre a argumentação

\footnotetext{
${ }^{52}$ ATIENZA, Manuel. "Is Legal Positivism a Sustainable Legal Theory?” In: GIZBERT-STUDNICKI, Tomasz; STELMACH, Jerzy. (Ed.). Law and Legal Cultures in the $21^{\text {st }}$ Century: Diversity and Unity. Plenary Lectures. Warszawa, Oficyna: 2007, p. 230. Este texto foi publicado em nosso país no livro Es el positivismo jurídico uma teoria aceptable del Derecho? In: (coord.) MOREIRA, Eduardo Ribeiro; PUGLIESI, Marcio. 20 anos da Constituição brasileira. Op. cit. . 71

ATIENZA, Manuel. Trás la justicia. Una introdicción al Derecho y al razonamiento jurídico. Barcelona, Editorial Ariel, 1995; Las piezas del Derecho. Teoria de los enunciados jurídicos. Barcelona, Editorial Ariel, 1996; As razões do direito. Teorias da argumentação jurídica. Perelman, Toulmin, MacCormick, Alexy e outros. São Paulo, Landy Editora, 2000 e El Derecho como argumentación. Barcelona, Editorial Ariel, 2006. Confira-se também sobre essa démarche argumentativa: BUSTAMANTE, Thomas da R. Teoria do direito e decisão racional. Temas de teoria da argumentação jurídica. Rio de Janeiro, Renovar, 2008; ABELLÁN GASCÓN, Marina e GARCÍA FIGUEROA, Alfonso. La argumentación en el Derecho .Lima, Palestra Editores, 2005; STAMATIS, Constantin M. Argumenter em droit. Une théorie critique de l'argumentation juridique. Paris, Éditions Publisud, 1995. (Este excelente livro, de pouco conhecimento do leitor brasileiro, apresenta um balanço preciso - de um profundo conhecedor da tradição jurídica alemã - acerca da virada teorética observada nos estudos jusfilosóficos a partir da consolidação das abordagens argumentativas. Cito aqui apenas uma passagem onde o autor grego, professor da Universidade Aristóteles de Tessalônica destaca uma questão central dentro da abordagem argumentativa, que por vezes não é percebida por alguns críticos equivocados: "Admitir, em teoria pelo menos, a justificabilidade dos julgamentos éticos, políticos e jurídicos não leva obrigatoriamente a insinuar uma ressurreição dos valores absolutos”, p. 120.
} 
O que caracteriza construtivamente o neoconstitucionalismo é a operacionalização da razão prática através de teorias da argumentação jurídica, em especial, as teorias padrão de Robert Alexy e Neil MacCormick. A tomada de consciência da doutrina jusfilosófica contemporânea - exemplificada, por exemplo, no trabalho de Manuel Atienza ${ }^{71}-$ de que o $^{2}$ direito é acima de tudo uma atividade argumentativa.

Como argumentação constitui uma questão central à tese sustentada nesse artigo permito-me incluir o verbete sobre argumentação publicado no Dicionário de filosofia do direito, (org.) Vicente de Paulo Barreto (Rio de Janeiro, Renovar, 2006, p. 60-64):

$$
* * *
$$

Argumentação (do latim argumentatio) é um processo pelo qual se reúnem argumentos e/ou dados convergentes no sentido de respaldar uma determinada tese. Argumentar significa, acima de tudo, fornecer razões que dêem suporte a certas conclusões; é, basicamente, uma atividade de justificação. Garante uma determinada qualidade a enunciados que pretendem, por serem fundamentados, gozar de aceitabilidade racional por parte dos auditórios aos quais são endereçados. Uma argumentação garante motivos para que se acredite em uma certa conclusão, razões geradoras de convicção. Argumentar significa defender uma pretensão com boas razões, expor essas pretensões às críticas, submetendo-as a uma espécie de banho cáustico propiciado pelo confronto de opiniões e pela troca de argumentos e contra-argumentos.

Explicitando melhor o que significa essa atividade humana básica, corolário de nossa competência comunicativa racional: trata-se de uma operação na qual se fornece um respaldo que possa lastrear uma tese em face de um interlocutor ou auditório. Argumentar implica oferecer um conjunto de elementos a favor de uma conclusão ou oferecer dados favoráveis a uma conclusão. Os argumentos são tentativas de sustentar certos pontos de vista com razões. Têm-se como elementos fundamentais dessa atividade: uma linguagem, posto ser a argumentação uma prática linguística que se realiza em um conjunto de enunciados; uma ou várias premissas funcionando como ponto de partida da argumentação; regras norteadoras dos passos aceitáveis para a passagem das premissas às conclusões. Saliente-se não se pautar a argumentação apenas nas regras de inferência reconhecidas como válidas pela lógica formal.

Segundo Manuel Maria Carrilho ${ }^{53}$, a argumentação consiste também, "de uma maneira geral, na defesa de um enunciado pela sua mise en rapport com outros enunciados." Sendo assim, é importante perceber que a argumentação, via de regra, se expressa por meio de uma rede, de uma teia argumentativa, mais ou menos cerrada, que garante a fidedignidade das conclusões. Ademais, argumentar caracteriza-se sempre por evitar que um enunciado esteja eivado de arbítrio, pois, como afirmam D. Folscheid e J. Wunenburger ${ }^{73}$, “é um procedimento que busca proteger um enunciado do arbitrário e da dúvida e conferirlhe uma verdade intrínseca que leve à convicção. Toda tomada de posição privada de argumento parece necessariamente uma opinião, uma asserção afirmada como um fato ou um ato de autoridade, que não justifica o que a autoriza a enunciar-se como verdade."

\footnotetext{
${ }^{53}$ CARRILHO, Manuel Maria. Rhétoriques de la modernité. Paris, Presses Université de France, 1992 , p. 95.

${ }^{73}$ FOLSCHEID, Dominique e WUNENBURGER, Jean-Jaques. Metodologia filosófica. São Paulo, Martins Fontes, 1997, p. 357.
} 
A argumentação consiste em uma sequência de proposições que visa a produzir ou reforçar o assentimento e o acordo de um ouvinte. Caracteriza-se por ser um processo discursivo e racional. Mas, em contraste com a própria lógica, não resulta em uma conclusão necessária que o ouvinte não pode rejeitar. O ouvinte permanece livre para aceitá-la ou recusá-la. A conclusão obtida em um processo argumentativo não é uma proposição necessária. Por se iniciar com proposições ou teses que são assumidas ou geralmente aceitas pelo auditório ou audiência a que ela está endereçada, a argumentação é sempre relativa a um auditório. Como os vínculos unindo os elementos de uma argumentação não são logicamente constringentes - verbi gratia, o uso de analogias, exemplos ou argumentos a fortiori ou a contrario sensu -, a passagem de um argumento a outro não é estritamente necessária. Portanto, não se chega à conclusão de uma argumentação que seja verdadeira ou falsa, mas sim que gere mais ou menos apoio dependendo do fato de os argumentos serem mais ou menos convincentes.

Lidar com questões que dividem os sujeitos: este é o desiderato da argumentação. Ela se inicia quando uma parte, em um diálogo qualquer, ergue uma pretensão de validade e a outra não concorda ou não acredita nela. Afinal, em determinadas situações da vida social, são afirmadas teses que pretendem ser levadas a sério. Tais reivindicações carregam em si um risco, pois ensejam ao interlocutor o direito de questionar essa afirmação, obrigando aquele que formulou tal assertiva a justificar, através de argumentos ou de dados da experiência, a fiabilidade das teses sustentadas. A qualidade das razões e a sua relevância podem ser sempre questionadas por um interlocutor insatisfeito, obrigando aquele que asseverou algo a enfrentar objeções e contra-argumentos, chegando até, em certos casos, a ser forçado a modificar suas teses iniciais. A argumentação é um processo autocorretivo.

Elemento central nas atividades que buscam solucionar problemas, a argumentação está inextricavelmente envolvida com processos de aprendizagem e pode gerar uma mudança em nossa opinião e conduta. Ela também é um processo de formação cooperativa do julgamento. Caracteriza-se por rejeitar qualquer tipo de afirmação dogmática, bem como por garantir defesas contra a manipulação tão presente em diversos aspectos do uso público da palavra.

A questão acerca do que torna uma argumentação sólida não tem uma resposta simples. A referência ao campo no qual ela se dá - direito, política, crítica de arte, estratégias de direção de empresas etc. - é fundamental. Certamente a capacidade de ser sustentada, de rechaçar as possíveis objeções, contra-argumentos e intentos de refutação, assim como a sua pertinência e suficiência em um dado contexto, garante a robustez de uma argumentação. $\mathrm{O}$ respeito a certos standards, como, por exemplo, não contradição e consistência na aplicação de predicados e expressões, garante também a força dos argumentos. A comprovação e a ponderação dos argumentos, bem como a busca de uma argumentação mais cogente e superior marcam o ofício daqueles dedicados às atividades intelectuais.

\section{Argumentação e seus desenvolvimentos contemporâneos}

O tema da argumentação tem merecido a atenção de um crescente círculo de pesquisadores nas últimas décadas, a par do alargamento da comunidade de investigadores no campo da filosofia interessados pela linguagem corrente. $O$ marco inicial deste movimento deu-se, coincidentemente, em 1958, com a publicação de duas obras - O Tratado da Argumentação, de Chaïm Perelman e Lucie Olbrechts-Tyteca, e Usos do Argumento, de 
Stephen Toulmin. Estas obras tornaram-se eixos a partir dos quais desenvolveram-se duas linhas de investigação - convergentes em relação aos alvos de suas críticas (o positivismo lógico e sua redução da ideia de argumentação aos cânones da lógica formal) e divergentes quanto às suas estratégias teóricas - responsáveis pelo desenvolvimento de um novo campo disciplinar (chamado por alguns de "lógica informal").

No caso de Perelman e Tyteca, o caminho adotado com a "nova retórica" notabilizouse por um resgate de uma influente tradição da Antiguidade greco-romana. Tal tradição retórica, desqualificada na Era Moderna - seguidora de ideais filosóficos científicos inspirados na matemática, na ideia de evidência e no conceito de sistema -, acabou sendo reduzida ao domínio da ornamentação dos discursos, vindo a ser caracterizada de forma quase pejorativa, como um discurso vazio e manipulatório. O esforço de Perelman e Tyteca consistiu em integrar as diversas elaborações intelectuais oriundas do mundo grego que desde o desmoronamento das visões míticas do mundo estabeleceram as coordenadas do pensamento racional - com a distinção entre aparência e realidade, o reconhecimento dos princípios da identidade, da não contradição e do terceiro excluído, e a busca de submeter o fluxo das palavras a uma medida. Assim, além de se inspirarem na retórica desenvolvida pelos sofistas, a articularam às reflexões de Aristóteles na Arte Retórica e nos Tópicos. Deste modo, se utilizaram não apenas das formas de argumentação dirigidas a qualquer massa não especializada, como nas técnicas do discurso público ensinadas pelos sofistas, mas inspiraram-se no refinamento discursivo operado por Platão com a dialética - que, embora crítico contumaz da retórica sofística, reconhece no diálogo Fedro (273c) a possibilidade de uma retórica capaz de convencer os deuses - e, também, sobretudo no tratamento aristotélico do tema.

Esclareça-se que desde Aristóteles a retórica divide-se em retórica dos conflitos e retórica das figuras. A que interessa a Perelman e Tyteca, a retórica dos conflitos, ocupa-se com a argumentação (na verdade confundindo-se com ela), a dialética, a intersubjetividade, os problemas e dilemas dos negócios humanos. Já a retórica das figuras remete ao estilo, ao ornamento e aparece associada à teoria literária. Interessa no corpus aristotélico não só a retórica, mas também a dialética - diferentemente da ciência demonstrativa que se utiliza do silogismo. A dialética, como definido nos Tópicos ${ }^{54}$, visa a "encontrar um método que nos torne capazes de argumentar sobre qualquer problema colocado, partindo de premissas prováveis, e de evitar, quando sustentamos um argumento, que afirmemos qualquer coisa que seja contrário a ele."

A nova retórica mobiliza uma série de elementos presentes na tradição retórica grecoromana, bem como estabelece certos procedimentos para a organização e dissociação de argumentos. Ideias como lugar comum (topos), presença, hierarquia de valores, lugares do preferível compõem um arsenal de elementos indispensáveis à estruturação de um processo argumentativo eficaz. Utiliza-se também de formas de ligação como: argumentos quase lógicos - incompatibilidade, identidade, definição, regra de justiça, transitividade, comparação; argumentos baseados na estrutura do real - como ligações de sucessão e de coexistência; ligações que fundam a estrutura do real - como exemplo, modelo, analogia, ilustração e metáfora. Uma grande novidade da nova retórica é o polêmico conceito de auditório universal.

\footnotetext{
${ }^{54}$ ARISTÓSTELES. Tópicos (100 a.), Livro I. In: The Works of Aristotle. Volume 1, Chicago, The University of Chicago, Great books of the Western World, 1971.
} 
Elemento capital à empresa perelmaniana, a noção de auditório universal se articula com o controverso problema da diferença entre persuasão e convencimento. Convencimento é o discurso argumentativo endereçado à ideia limite de auditório universal. Persuasão está referenciada a um auditório específico, levando em consideração, necessariamente, as características de tal auditório e recorrendo, assim, a elementos de natureza psicológica. $\mathrm{O}$ convencimento supõe a utilização de teses consideradas verdadeiras por quem as alega. A persuasão carrega no seu bojo a presença de interesses, nem sempre justificáveis. Embora Perelman identifique essa distinção como crucial, por vezes, dentro de sua abordagem não encontramos subsídios para distinguir essas duas perspectivas (o crivo para estabelecer tal distinção reconhece-se mais nitidamente na teoria da argumentação de Habermas, com a utilização da noção de situação ideal de fala). Assim, o discurso persuasivo é um discurso ad hominem, enquanto o discurso convincente é ad humanitatem.

Um outro elemento crucial à inteligência do escopo do projeto perelmaniano encontra-se na diferença entre argumentação e demonstração. A argumentação se define também diferenciando-se da demonstração. Enquanto esta utiliza-se de uma linguagem artificial - sistema de signos, axiomas e regras de transformação, como, por exemplo, na álgebra e na química -, com o fito de evitar a ambiguidade e lograr a univocidade, a argumentação emprega a linguagem natural. A demonstração segue os raciocínios lógicoformais, chegando a conclusões necessárias e universais. A argumentação se utiliza de técnicas capazes de despertar ou aumentar a adesão dos espíritos às teses que são apresentadas à sua apreciação e chega a resultados mais ou menos fortes. A demonstração repousa na ideia de evidência, diante da qual todo homem racional é forçado a ceder, já a argumentação não aceita a ideia de que toda prova seria redução à evidência.

Tanto a teoria da argumentação de Perelman quanto a de Toulmin se originam de suas preocupações com o domínio da ética. A necessidade imperiosa de garantir alguma forma de controlabilidade racional ao campo das decisões, eleições, condutas e opções valorativas funcionou com um aguilhão na carne normativa desses dois pensadores, testemunhas da barbárie nazista. $\mathrm{O}$ desenvolvimento de suas diferentes teorias de argumentação (a retórica filosófica de Perelman e a lógica argumentativa de Toulmin) converge no esforço de submeter o domínio dos negócios humanos a parâmetros capazes de balizar a ação na conturbada realidade social na qual se desenrola a vida coletiva dos seres humanos, encontrando meios não violentos para dirimir os inevitáveis conflitos dela decorrentes. Saliente-se também um outro elemento comum a ambas empresas filosóficas: a utilização do modelo do direito. $\mathrm{O}$ reconhecimento da pertinência dos cânones básicos do processo judicial, verdadeira decantação de dois mil anos de experiência de aprendizado jurídico, serve como um modelo alternativo à geometria e à matemática, "musas inspiradoras" de todas as diferentes versões do positivismo.

Embora se assemelhe em muitos aspectos ao projeto da nova retórica, a "lógica argumentativa" desenvolvida por Toulmin segue um caminho diferente. Não é na tradição greco-romana que se encontram os elementos capacitadores de estabelecer um enfoque teórico crítico às posições do positivismo lógico, dominante no quadro filosófico angloamericano, que com seu avatar logicista só reconhece como argumentos válidos aqueles que seguem o modelo de inferência dedutiva-analítica. Entretanto, com as transformações operadas no âmago da tradição analítica, com a abertura do campo de exame da linguagem ordinária, Toulmin, aluno de Wittgenstein, amealhou elementos capazes de estabelecer um projeto filosófico ambicioso, nascido do descontentamento com as visões absolutistas, que só reconheciam as evidências empíricas constringentes e os argumentos dedutivos conclusivos 
como capazes de lastrear o conhecimento teórico e o insight moral prático (afinal, segundo a posição analítica ortodoxa, a argumentação válida só se dá através da dedução).

Toulmin chegou à conclusão de que era um absurdo reduzir o termo "argumentação racional" ao âmbito da lógica formal e das ciências da natureza. Assim, procurou mover a filosofia além do foco estreito da lógica formal, pois, desde o Iluminismo, há uma fixação na lógica dedutiva e na certeza evidencial como únicos caminhos para capturar a racionalidade; no entanto, estes são caminhos estreitos para dar conta da racionalidade argumentativa e de diversas formas de investigação científica. Portanto, não aderir a cânones demonstrativos não implica necessariamente a falta de standards normativos para definir um bom argumento. Ora, também argumentamos em terrenos como o direito, a moral, a arte, a direção de empresas etc. Em todos eles a estrutura da argumentação consta essencialmente dos mesmos passos: defender uma pretensão com boas razões, expor essas razões à crítica, e, se necessário, modificar nossa opinião ou conduta a partir dos resultados obtidos desta contraposição de informações.

Toulmin desenvolveu um modelo capaz de dar conta da estrutura da argumentação nos seus diversos campos de aplicação. A estrutura de um argumento substantivo é composta de quatro elementos: uma conclusão (C), dados angariados em seu favor (Data - D), aquilo que autoriza a fornecer esses dados para aquela conclusão (Warrant - W) e as evidências casuísticas que apóiam W (Backing - B).

O modelo desenvolvido por Toulmin serviu de referência fundamental às elaborações teóricas de Jürgen Habermas, possivelmente o filósofo contemporâneo mais focalizado na problemática da argumentação (visto que essa atividade está estreitamente ligada à ideia de agir comunicativo, que, por sua vez, é elemento axial à reprodução do mundo-da-vida categoria capital à arquitetônica teorética habermasiana).

A ideia central de Habermas ${ }^{55}$ no tocante à sua teoria da argumentação consiste na noção de "sistema de pretensões de validade". Como ele afirma, "argumentos são meios através dos quais o reconhecimento intersubjetivo de pretensões de validade hipoteticamente erguidos por algum proponente pode ser alcançado e assim opiniões são transformadas em conhecimento". As pretensões de validade, que podem ser discursivamente resgatadas, são erguidas em relação a três regiões da realidade, segundo diferentes aspectos de racionalidade: uma pretensão de validade pode ser erguida na dimensão da verdade, em face de eventos da natureza externa; uma outra pretensão diz respeito à correção das normas de ação encontradas na dimensão intersubjetiva aberta pela vida social, onde se dá a integração através de normas e valores; e, por fim, uma pretensão de veracidade e sinceridade pode estar presente nos proferimentos ligados à expressividade de estados internos. As pretensões de validade podem ser resgatadas ou honradas por meio de argumentos.

A prática argumentativa conecta-se a uma forte antecipação idealizante expressa no controvertido conceito de situação ideal de fala (semelhante à ideia de auditório universal), recurso utilizado por Habermas para justificar a plausibilidade do discurso prático elaborada em seu texto "Teorias da verdade" ${ }^{56}$, de 1972. Esse construto teórico recorre a certas pressuposições idealizadas como as de que todos os participantes devem ser verídicos, todos os interessados podem participar, todos podem problematizar qualquer afirmação, todos

\footnotetext{
${ }^{55}$ HABERMAS, Jürgen. The Theory of Communicative Action. Vol I. Reason and the Rationalization of Society. Boston, Beacon Press, 1984. 56 "Teorias de la verdad". Teoría de la acción comunicativa: complementos y estudios prévios. Madrid, Cátedra, 1994.
} 
podem introduzir quaisquer argumentos e de que nenhum participante pode ser coagido. Estas condições especificam uma norma de comunicação que traz em si um impulso de "reciprocidade igualitária". Disso decorre que a utilização do expediente da situação ideal de fala não supõe que tais condições ocorram simultaneamente na vida real. Ela se caracteriza por ser uma noção contrafática, um ideal a ser perseguido, nunca plenamente realizável, mas que funciona como um parâmetro crítico à avaliação dos processos argumentativos concretos. Cabe sublinhar ser próprio de uma situação contrafática o dado de que o descumprimento de algum de seus pressupostos não implica a invalidação deste construto teórico, vale dizer, a não observância empírica dos ditames previstos em tal situação não acarreta a sua ineficácia. A qualidade ou característica que atribui a algum elemento teórico o estatuto de contrafático implica necessariamente a sua potencial contestabilidade.

A argumentação, para Habermas, pode ser compreendida como uma pugna em torno dos melhores argumentos a favor de ou contra uma pretensão de validade controvertida e serve à busca da verdade. Verdade, marcada por um espírito falibilista, entendida como aceitabilidade racional. Os critérios elencados nas suas reflexões sobre argumentação e referenciados à situação ideal de fala possibilitam pensar na ideia de um consenso não coarctado, isto é, em uma aceitação racional de pretensões de validade. Tal processo repousa na convicção intuitiva de que há uma diferença entre convencer e persuadir, entre motivação mediante razões e influência causal, e entre aprendizagem e doutrinamento. Por fim, não menos importante o espraiar de uma cultura argumentativa contribui para a democracia.

$$
* * *
$$

Quanto aos desdobramentos no âmbito da argumentação jurídica da perspectiva supra apresentada confira-se o verbete "Argumentação jurídica" coescrito com Thomas da Rosa Bustamante. In: BARRETO, Vicente de Paulo (org.). Dicionário de Filosofia do Direito. Rio de Janeiro/ São Leopoldo, Renovar/Editora Unisinos, 2006, p.64-68. Sirvo-me também da cogente argumentação de Thomas a respeito da questão crucial no âmbito metodológico do paradigma neoconstitucionalista: a racionalidade da ponderação de princípios. Nesse sentido remeto o leitor à primeira parte de seu livro, Teoria do direito e decisão racional, op. cit, p. 15-139. 
II - As transformações dos sistemas jurídicos contemporâneos: acerca do neoconstitucionalismo

(...) paradigmas legais tornam possível o diagnóstico de situações e servem de guias à ação. Eles iluminam o horizonte de uma dada sociedade, tendo em vista o projeto de realização do sistema de direitos.

Jürgen Habermas

As transformações observadas em sistemas jurídicos avançados, como já salientado, têm demandado esforços à reflexão teórica: imperioso o desenvolvimento de um novo quadro de referência capaz de dar conta das significativas mudanças acarretadas pela implementação do Estado democrático constitucional contemporâneo. Na primeira parte deste artigo, esta constelação teórica, na década de 90, foi caracterizada como póspositivista. Todas as características apontadas na primeira parte deste trabalho ensejam o quadro mais geral no qual se anuncia a mudança para o novo paradigma jurídico, em construção, o neoconstitucionalismo. Na segunda parte deste trabalho, estas mesmas transformações compreender-se-ão a partir de um quadro geral de referencia mais amplo: por um lado, no âmbito da Teoria do Estado, indaga-se sobre a nova forma assumida pela tradicional concepção acerca da divisão dos poderes (com o incremento de atribuições do Judiciário); Por outro, como também já salientado, incorporando os avanços no campo da filosofia moral - trazendo no seu bojo a ideia de reabilitação da razão prática através do construtivismo kantiano - e a constatação de que o eixo central dos debates metodológicos contemporâneos se dá no campo da argumentação jurídica. Em 2003, com o surgimento do livro Neoconstitucionalismo(s), o debate sobre as insuficiências do positivismo jurídico à inteligência dos sistemas jurídicos avançados passou a ser tematizada de forma mais ousada apontando-se, enfim, uma saída a este impasse que envolve - desde o fim da II Guerra Mundial - os jusnaturalistas racionalistas (como Gustav Rardbruch e Lon Fuller) - e os juspositivistas. A análise desta nova conjuntura ocupa agora o centro das considerações aqui expostas.

A principal mudança refere-se ao papel desempenhado pelo texto constitucional em nações da tradição continental - Alemanha, Itália, Espanha e Portugal (e ipso facto nos países de tradição romano-germânica na América Latina). Não mais um texto que sirva como um "esboço orientativo que deve ser simplesmente 'respeitado' pelo legislador" mas 
sim um “programa positivo de valores que deve ser 'atuado' pelo legislador". ${ }^{57}$ Assim, como esclarece também Sastre Ariza sobre esta mudança do papel desempenhado por certas textos legais contemporâneos, "as constituições atuais são limite e direção ao mesmo tempo"78. Desta forma o constitucionalismo europeu contemporâneo reconhece por um lado a tradição liberal que entende a ordem constitucional como um instrumento par excellence de garantia da esfera mínima intangível de liberdade dos cidadãos e, por outro, incorpora as modificações consagradas no perfil do constitucionalismo a partir do modelo das Constituições alemã e italiana do pós-guerra. Com efeito, como sintetiza Prieto Sanchís "A constituição já não é mais uma norma normarum à moda de Kelsen, encarregada somente de distribuir e organizar o poder entre os órgãos estatais, mas é uma norma com amplo e denso conteúdo substantivo que os juizes ordinários devem conhecer e aplicar a todo conflito jurídico" 58 .

A incorporação de conteúdos substantivos no ápice das estruturas legais, com a rematerialização da Lei Maior, implicou, entre outras coisas, uma nova forma de enfrentar a vexato quaestio da filosofia do direito: as relações entre direito e moral ${ }^{59}$ - já que os princípios constitucionais abriram uma via de penetração moral no direito positivo.Como afirma Ralf Dreier, "as constituições políticas de determinados Estados, ao incorporar certos princípios (dignidade da pessoa humana, solidariedade social, liberdade e igualdade) ao direito positivo como princípios juridicamente válidos e como expressão da ética política moderna, estabeleceram uma relação necessária entre direito e moral, já que graças a ela se exige, por direito próprio, em casos de vaguidade e colisão, aproximar a noção do direito como ele é do direito como ele deve ser." ${ }^{60}$ Assim, estas transformações, que ocorreram também em nossa experiência legal - em especial a inclusão de um largo catálogo de direitos fundamentais e inúmeros princípios jurídicos, observada a partir de 1988 -, demandaram a necessidade de criação de uma categoria para descrever, compreender e melhor operacionalizar a aplicação efetiva dos materiais normativos positivados em nossa Constituição Cidadã.

\footnotetext{
${ }^{57}$ Sigo aqui Sastre Ariza, em Ciência jurídica positivista y neoconstitucionalismo. Madrid, McGraw Hill, 1999, p.130, que neste particular cita Zagrebelsky em El derecho dúctil. ley, derechos, justicia.. Madrid, Editorial Trotta, 1995. ${ }^{78}$ Idem, p. 131.

${ }^{58}$ PRIETO SANCHÍS, Luis. Jueces y justicia em tiempos de constitucionalismo - entrevista al Profesor, Luis Prieto Sanchís. Entrevista realizada por Pedro P. Grández Castro (mimeo). Toledo, 2005, p. 4.

${ }^{59}$ Como afirma Alfonso García Figueroa sobre os direitos fundamentais "os direitos fundamentais reforçam assim um fenômeno mais amplo: o imbricamento do raciocínio jurídico e raciocínio moral, que apresenta relevância justeórica no sentido de que exige a superação do paradigma que rege a dialética positivismo/jusnaturalismo em favor de um modelo neoconstitucionalista. As consequências no plano justeórico deste posicionamento são: o rechaço ao dualismo direito/moral em favor de um gradualismo entre ambos os termos e o rechaço ao objetivismo em favor da tese da disposição à correção alternativa, tanto da tese da separação positivista como da tese da vinculação jusnaturalista; tudo isso com a introdução do construtivismo ético e do constitucionalismo dentro do acervo teórico do direito". FIGUEROA, Alfonso García. "La incidencia de la derrotabilidad de los principios iusfundamentales sobre el concepto de Derecho". In: Diritto \& Question Publiche. N. 3, 2003, p. 197.

${ }^{60}$ DREIER, Ralf. "Derecho y Justicia”, Monografias jurídicas 87. Bogotá, Temis, 1994, p. 82-83, apud ARANGO, Rodolfo. ¿Hay respuestas correctas en el derecho? Santafé de Bogotá, Siglo del Hombre Editores, 1999, p. 126. A figura de Ralf Dreier, merecerá maior atenção em uma próxima exposição desta pesquisa, pois seu trabalho está estreitamente vinculado ao de seu ex-assistente Robert Alexy, constituindo uma das abordagens teóricas que contribuíram à construção deste novo paradigma jurídico, o neoconstitucionalismo.
} 
Estas transformações impuseram à nossa dogmática constitucional, como exposto no item I deste trabalho, a necessidade de elaboração de uma nova referência, como a utilizada na década de 90, o pós-positivismo, situando assim o pensamento jurídico contemporâneo para além da estiolada querela jusnaturalismo versus positivismo jurídico. Entretanto, como não poderia deixar de acontecer em nações periféricas, a reflexão teórica aqui desenrolada está sobredeterminada pelos influxos especulativos das culturas jurídicas mais maduras. Ora, no debate norte-atlântico, em especial na tradição continental européia, observaram-se transformações semelhantes àquelas ocorridas em nossa formação social; entretanto, o termo pós-positivismo não tinha se consagrado como o mais apto à descrição desta nova configuração legal. Eis que esta nova realidade jurídico-constitucional que ensejou o surgimento da categoria pós-positivista em nosso âmbito cultural vem sendo denominada nas doutrinas espanhola e italiana neoconstitucionalismo.

Agora, procurarei apresentar algumas características deste novo paradigma (também chamado de constitucionalismo de direitos, constitucionalismo avançado ou simplesmente paradigma argumentativo) Tal reflexão relaciona-se com um debate atual no âmbito das letras jurídicas: a constitucionalização do direito. Tal articulação se dá na medida em que a progressiva extensão da argumentação baseada em princípios e direitos fundamentais alcança os mais diferentes campos do direito positivo. A apresentação do tema do neoconstitucionalismo se dará, em primeiro lugar, a partir de uma contextualização referenciada às transformações operadas no sistema jurídico brasileiro ${ }^{61}$; em segundo lugar, enfocarei o neoconstitucionalismo sob três aspectos: no primeiro sentido, o neoconstitucionalismo como um certo tipo de Estado de direito caracterizando uma determinada forma de organização política; no segundo sentido, entende-se como uma teoria do direito que serve para descrever e operacionalizar o mais criteriosamente possível este modelo e, no terceiro sentido, uma filosofia política ou ideologia que justifica esse modelo.

Ademais, a doutrina jurídica contemporânea constata que "é difícil encontrar uma acomodação para os valores e princípios nos esquemas tradicionais mais ou menos herdados

\footnotetext{
${ }^{61}$ Tem crescido na literatura nacional as referências ao neoconstitucionalismo. Sem querer ser exaustivo em relação a esta bibliografia, pode-se salientar que desde 2006 tem-se, por exemplo, POZZOLO, Suzanna e DUARTE, Écio Oto Ramos. Neoconstitucionalismo e positivismo jurídico: as faces da teoria do Direito em tempos de interpretação moral da Constituição, op.cit.; referências também ao neoconstitucionalismo nos textos de MOREIRA NETO, Diogo de Figueredo. "Direitos Humanos, legitimidade e constitucionalismo" e BARCELLOS, de Ana Paula. "Neoconstitucionalismo, direitos fundamentais e controle das políticas públicas" In: SARMENTO, Daniel e GALDINO, Flávio (orgs.). Direitos Fundamentais: estudos em homenagem ao professor Ricardo Lobo Torres. Rio de Janeiro, Renovar, 2006. Também sobre esta temática: "Não se olvide que aquilo que a doutrina tem designado como 'neoconstitucionalismo', em princípio, não substancia, organicamente, uma nova teoria constitucional ou um movimento doutrinário. Antes disso parece tratar-se, o 'neoconstitucionalismo', em verdade, de um movimento teórico em que os constitucionalistas buscam a superação de modelos jurídicos positivistas e formalistas projetados ao discurso e dogmática constitucionais. Um momento em que se busca soluções mais adequadas para as questões constitucionais diante das insuficientes respostas positivistas. Daí, então, justifica-se o entendimento de não haver sempre convergência entre os diversos modelos do pensamento 'neoconstitucionalista'." SCHIER, Paulo Ricardo. "Novos Desafios da Filtragem Constitucional no Momento do Neoconstitucionalismo". In: REDE - Revista Eletrônica de Direito do Estado. N. 4 - out - dez de 2005, Salvador: IDPB, p. 5. O uso pioneiro da expressão neoconstitucionalismo em nossas letras jurídicas deu-se no volume (NEO)CONSTITUCIONALISMO: ontem, os códigos hoje, as constituições, Revista do Instituto de Hermenêutica Jurídica. Porto Alegre, 2004. Também sobre esta problemática conferir a importante coletânea: DIMOULIS, Dimitri e DUARTE, Écio Oto. Teoria do direito neoconstitucional. Superação ou reconstrução do positivismo jurídico? Op. cit.
} 
do positivismo. As mais genuínas normas constitucionais carecem com frequência de determinação fática ou determinação jurídica, quando não de ambas." ${ }^{\text {62 }}$ Assim, impõe-se o desenvolvimento de uma nova metodologia jurídica, apta a oferecer elementos à operacionalização e parametrização - garantindo pelo menos um incremento de racionalidade à aplicação dos princípios constitucionais - da nova situação encontrada em determinados sistemas jurídicos que adotam o modelo do Estado democrático contemporâneo.

As considerações que gostaria de expor têm relação com as consequências jusfilosóficas ${ }^{63}$ acarretadas pela inclusão nos textos constitucionais contemporâneos de vários standards morais, na forma de princípios, valores e direitos fundamentais, já que tais standards realizam uma plasmação jurídica de conteúdos de natureza moral nos ordenamentos jurídicos hodiernos. Tal incorporação coloca em xeque elementos básicos do paradigma jurídico dominante até o fim dos anos 60, o positivismo jurídico. Pensemos, por exemplo, no fato de que nas constituições contemporâneas “(...) contra as advertências feitas por Kelsen, se incorporam conteúdos materiais que adotam a forma de direitos, princípios, diretrizes e valores. Essas disposições constitucionais apresentam um alto grau de indeterminação, destacando, principalmente, o tipo de vaguidade que oferecem os conceitos essencialmente controversos (como, por exemplo, dignidade, justiça, liberdade e autonomia), que expressam um conteúdo com forte carga valorativa difícil de precisar" ${ }^{\prime 85}$. Eis que a grade teórica proposta pelo positivismo jurídico para dar conta da interpretação legal encontra dificuldades para apreender essa nova realidade do direito constitucional contemporâneo: em primeiro lugar, por lastrear a aplicação do direito na ideia de subsunção - incapaz de dar conta da especificidade da aplicação dos princípios, em especial nos frequentes casos de colisão -, em segundo lugar, por ser tributária de uma percepção do fenômeno jurídico reducionista - na medida em que não desenvolveu um aparato teórico capaz de apreender racionalmente os incontornáveis elementos políticos e morais presentes nas razões dadas aos casos difíceis.

Muito do trabalho intelectual que tem sido realizado pela teoria constitucional em nosso país, como já destacado, reconhece a lição de Paulo Bonavides "de que a teoria dos princípios é o coração das Constituições na era do pós-positivismo", bem como se inspira numa concepção expansiva dos direitos fundamentais ${ }^{86}$. Os doutrinadores que vêm desenvolvendo seus afazeres no campo jurídico parametrizados por essa nova constelação

\footnotetext{
${ }^{62}$ PRIETO SANCHÍS, Luiz. Constitucionalismo y positivismo. México, Distribuciones Fontamara, 1999, p. 33. Também, no mesmo texto (pág. 30) no tocante às características que ensejam dificuldades de apreensão das atuais normas constitucionais à luz das ferramentas metodológicas do positivismo tradicional, afiram também Prieto Sanchís que "Estas [normas constitucionais A.C. Maia] (...) qualificam-se de incompletas, vagas, abstratas, gerais, de aplicação diferida, etc."

${ }^{63} \mathrm{~A}$ análise aqui elaborada parte do ponto de vista da filosofia do direito, sendo assim, são deixadas de lado as complexas questões quanto à aplicação controlada dos princípios. O que interessa nesta exposição são as repercussões no âmbito da autocompreensão dos teóricos do direito acerca das duas referencias paradigmáticas tradicionais desta disciplina - jusnaturalismo e positivismo. Assim, por dever de ofício - e limites de competência teórica - preocupo-me mais com o âmbito da justificação do que com o da aplicação. Quanto ao domínio da metodologia jurídica, no campo do direito constitucional, na literatura nacional assistimos, nos últimos anos, a uma sensível sofisticação doutrinária, como, por exemplo, nos trabalhos de Ingo Sarlet, Humberto Ávila e Virgílio Afonso da Silva.

85 ARIZA, Santiago Sastre. "La ciência jurídica ante el neoconstitucionalismo". In: CARBONELL, Miguel.

(org.) Neoconstitucionalismo(s). Madrid, Editorial Trotta, 2003, p.241.
} 
teórica seguem pelo menos duas ordens de motivação: por um lado, ela propicia uma mais fidedigna descrição de nosso sistema legal atendendo às exigências do desenvolvimento do pensamento científico e, por outro, é mais adequada às possibilidades de uma utilização progressista, isto é, democrática - igualitária, marcada por um viés redistributivo, já que busca criar mecanismos capazes de efetivar os direitos fundamentais. (Saliente-se, mais uma vez, a tormentosa questão do entendimento da natureza de direito fundamental dos direitos sociais).

Importa observar que essas transformações operadas no panorama constitucional das ultimas décadas implicaram consequências no plano da autocompreensão dos experts em direito, em especial, daqueles ligados ao campo da teoria do direito, há décadas envolvidos no estiolado debate jusnaturalismo vs. positivismo. Não foi gratuita a utilização da rubrica pós-positivista: fez-se necessário marcar a diferença em face da compreensão até então hegemônica. Afinal, tem-se que tratar agora com as novas características e desafios resultantes da evolução do direito contemporâneo. Como descrito por Luis Pietro Sanchís, lidamos hoje, em especial do ponto de vista do constitucionalista:

Mais princípios que regras; mais ponderação que subsunção; onipresença da Constituição em todas as áreas jurídicas e em todos os conflitos minimamente relevantes, em lugar de espaços extensos em favor da opção legislativa ou regulamentadora; onipotência judicial em lugar da autonomia do legislador ordinário e por ultimo coexistência de uma constelação plural de valores, por vezes tendencialmente contraditórias, em lugar de uma homogeneidade ideológica em torno de um pequeno grupo de princípios coerentes entre si e em torno, sobretudo, das sucessivas opções legislativas. ${ }^{64}$

Essa nova configuração teórica, em gestação nas últimas duas décadas, tem sido caracterizada no Brasil como pós-positivismo, cujo panorama geral já foi aqui exposta. Tal nomenclatura tem circulado amplamente entre nossos constitucionalistas, embora muitas vezes não atentem às consequências jusfilosóficas desta tomada de posição, posto que ela implica um rompimento com os paradigmas tradicionais do pensamento jurídico. Já na doutrina continental européia, em especial no âmbito de um crescente debate envolvendo o mundo hispano falante e italiano, essas transformações no campo do direito acarretaram a necessidade do desenvolvimento de um sistema de categorias identificatório da nova realidade observada nos ordenamentos jurídicos contemporâneos dado o fenômeno da principialização dos sistemas jurídicos e da correlata constitucionalização do direito. Este novo paradigma, como já destacado, tem sido chamado de "neoconstitucionalismo",

${ }^{64}$ SANCHÍS PRIETO, Luis. Justicia constitucional y Derechos fundamentales. Madrid, Editorial Trotta, 2000, p. 132.88

Quanto à oscilação terminológica acerca desse novo paradigma jurídico confira-se, por exemplo, as referências de Carla Faralli - em texto, publicado em 2005, continuador da monumental história da filosofia do direito realizada por Guido Fassò - :" a denominação das recentes teorias do direito que tem posto em seu centro o processo de constitucionalização do direito ainda não se encontra consolidada: há quem fala de "neoconstitucionalismo" (por exemplo, BARBERIS, Filosofia del diritto, cit., p. 203; "Neoconstituzionalismo democrazia e imperialismo della morale", em Ragion pratica, 2000, pp. 147 y ss.); quem fala de "teorias constitucionalistas" (por exemplo, G. BONGIOVANNI, Constituzionalismo e teoria del diritto, Roma-Bari, 2005); e quem se refere a "teorias principialistas" (cfr. A. GARCÍA FIGUEROA, Principios y positivismo jurídico: el no positivismo principialista en las teorias de Ronald Dworkin y Robert Alexy, Madrid, 1998)". In: FARALLI, Carla. La filosofia del derecho contemporânea: Los temas y desafíos. Bogotá, Universidad Externado de Colombia, 2007, p. 27. 
"constitucionalismo avançado" ou "constitucionalismo de direitos". Tais rubricas ${ }^{88}$ pretendem apontar para um novo patamar na história do pensamento jurídico ocidental e surgem para dar resposta às insatisfações teóricas observadas nas ultimas décadas.

A pletora de categorias teóricas propostas nos últimos anos para dar conta das transformações no direito constitucional - e de suas consequências no âmbito jusfilosófico é sintomática do desconforto vivenciado por certos teóricos do direito, sobretudo no fronte positivista, vis-à-vis ao movimento capitaneado por Ronald Dworkin, Robert Alexy e Carlos Santiago Nino. Como afirma Sastre Ariza ${ }^{65}$, muitos autores têm se esforçado em realizar uma compatibilização entre o positivismo jurídico e o novo quadro constitucional. Apresentam como denominador comum um esforço de sustentar o fato de que as ferramentas teóricas propugnadas pelos positivistas são ainda úteis e capazes de dar conta dos problemas postos aos operadores do direito contemporâneo. Assim, ainda seguindo o magistério de Sastre Ariza, falamos de positivismo crítico (Ferrajoli), positivismo corrigido (Peces-Barba), positivismo inclusivo (Wilfrid Waluchow), positivismo soft (Hart), póspositivismo (Calsamiglia), positivismo sofisticado (Shiner) e positivismo incorporacionista (Coleman).

Importa observar que ao discutir-se esse esforço de categorização do novo patamar do pensamento jurídico ocidental estamos lidando ainda com um debate não consolidado, vale dizer, as posições teóricas estão se rearranjando em torno do esforço de propor uma grade de inteligibilidade capaz de dar conta da dinâmica jurídica do Estado constitucional contemporâneo. Não é episódico o fato de ser o título da principal obra apresentadora desse novo quadro: Neoconstitucionalismo(s). O uso do plural denota o fato de que existem duas abordagens conflitantes no esforço de dar conta de algo que já é dado como certo: a insuficiência dos modelos tradicionais - oriundos do constitucionalismo liberal - à compreensão da dinâmica jurídica hodierna.

Por um lado, temos o neoconstitucionalismo não positivista (em sua versão continental), exemplificado no trabalho de Robert Alexy (e também com algumas diferenças em Gustav Zagrebelsky ${ }^{66}$ ). Nesta vertente aposta-se, em especial no caso de Alexy, na reabilitação da

${ }^{65}$ Cf. ARIZA, Sastre. "La ciência jurídica ante el neoconstitucionalismo", opus cit. p. 245. 86

Também precursor desta abordagem em nosso país o colega de doutor Paulo, Willis Guerra Filho, que em 2002 afirmava no item 18, intitulado "A superação do positivismo", de seu livro Teoria processual da Constituição, São Paulo, Celso Bastos Editora, o seguinte: "E plano jusfilosófico, a antítese registrada [jusnaturalismo versus positivismo, A.C.M] exprime-se no confronto, sempre renovado, entre posições que se apegam ao direito positivado, como o único dotado de validade, e aquelas que, de uma forma ou de outra, não reconhecem uma cisão total entre Ser e Dever-Ser jurídico, buscando, assim, quer em um plano fático, quer em outro plano, o metafísico, a verdadeira fonte da validade jurídica.

\footnotetext{
${ }^{66}$ Quanto a Zagrebelsky, a próxima exposição desta pesquisa tratará com mais detalhe a obra deste constitucionalista. O seu livro Direito dútil (em especial o capítulo VI - tipicamente neoconstitucionalista) causou um enorme impacto no pensamento jurídico hispano-falante com sucessivas edições desde 1995. Acredito, e só poderei expor melhor esta tese em outra ocasião, que parte significativa da reprovação endereçada ao neoconstitucionalismo pela Escola positivista de Genova - com Paolo Comanducci, Suzanna Pozzolo e Mauro Barberis - está endereçada ao trabalho de Zagrebelsky (não só doutrinador teórico, mas também membro da corte constitucional italiana). Há também certamente por parte destes autores italianos uma reprovação à empresa dworkiniana; em relação a Alexy, a questão é mais complexa: por um lado, não conheço reflexões destes autores diretamente referias ao filósofo de Kiel; e, por outro, a posição do protagonista da teoria discursiva do direito e democracia afigura-se como muito mais complexa e de difícil crítica. $91 \mathrm{~A}$ apresentação e defesa do paradigma neoconstitucionalista em sido o motor central da obra deste jovem constitucionalista e jusfilósofo colombiano. Tradutor de Alexy e professor da Universidad Externado de
} 
razão pratica - dimensão não reconhecida entre nossas capacidades cognitivas por parte dos teóricos positivistas - e na centralidade dos princípios constitucionais à inteligência dos sistemas jurídicos contemporâneos avançados. Seguindo esse posicionamento teórico temos também autores espanhóis como Luis Prieto Sanchís, Alfonso Garcia Figueroa e Santiago Sastre Ariza. Assim como Carlos Bernal Pulido ${ }^{91}$.

Por outro lado, pode-se indicar uma vertente do neoconstitucionalismo alinhada com o positivismo inclusivo, assim como afirma Luis Prieto Sanchís o "constitucionalismo se conecta muito bem com o chamado positivismo inclusivo ou incorporacionista" ${ }^{67}$ Alinhamse nessa perspectiva além do jusfilósofo supramencionado, José Juan Moreso. Tal vertente apresenta elementos comuns com importantes teóricos italianos como Paulo Comanducci e Susana Pozzolo. Tais autores filiam-se - juntamente com Riccardo Guastini - à forte tradição positivista italiana, de inicio de inspiração kelseniana, representada no trabalho de Norberto Bobbio, e sofisticada pelo aporte técnico da filosofia de corte analítico, e, nos anos 70, desenvolvida com a incorporação dos aportes oriundos da filosofia da linguagem ordinária, exemplificado no magistral trabalho de Herbert Hart (no caso italiano, nesta perspectiva, não esqueçamos a figura de Uberto Scarpelli). Entretanto não resta claro o posicionamento desta escola italiana, pois embora teçam reservas ao neoconstitucionalismo não positivista, não parece que abracem a posição do positivismo exclusivo, como sustentado pelo positivismo normativista de Eugenio Bulygin e seus seguidores.

Acredito não ser necessário despender uma longa cadeia de argumentos para sustentar a pertinência, para um observador da cultura jurídica brasileira, deste debate travado entre as tradições jurídicas de língua italiana e espanhola. Com efeito, em primeiro lugar, são inúmeras as semelhanças culturais entre essas duas tradições e o Brasil - muito mais, por exemplo, que a tradição da commom law, tão a gosto de nossos constitucionalistas liberais -, (como na mesma direção deste argumento sustente o jusfilósofo Pedro Serna - animador de um importante grupo de pesquisadores em La Coruña - ao afirmar: "Aliás, permite também tomar certa distância crítica a respeito de algumas entradas levadas a cabo entre nós recentemente, que insistem em limitar exclusivamente suas fontes à literatura anglo-saxã. Em minha opinião, o neoconstitucionalismo europeu e boa parte dos problemas que coloca não procedem dos Estados Unidos senão da Alemanha, e se compreendem melhor por referência ao âmbito alemão, que é o que tem exercido uma influência mais direta sobre nosso Direito [espanhol, A.C.M], que o anglo-saxão." ${ }^{68}$ ); em segundo lugar, ambas as tradições - à semelhança do que tem ocorrido conosco há menos tempo - procuram oferecer

Colombia (cuja produção editorial na coleção de Teoria Jurica y Filosofia del Derecho constitui foco cardeal na divulgação das novas ideias jurídicas na comunidade ibero-americana). Não é por acaso que seu principal livro, referência incontornável nos estudos constitucionalistas, El principio de proporcionalidad y los derechos fundamentales, Madrid, CEC, 2007, trata de uma questão absolutamente central à pretensão de racionalidade da ponderação de princípios - elemento central do neconstitucionalismo. A sua participação mediando o debate entre Priento Sanchís e Juan García Amado no texto "Refutación y defensa del neconstitucionalismo" In: CARBONELL, Miguel (Ed.) Teoría del neoconstitucionalismo: ensayos escogidos é brilhante. Recentemente publicou El neoconstitucionalismo y la normatividad del derecho, Bogotá, Universidad Externato de Colombia, 2009.

${ }^{67}$ SANCHÍS, Luis Prieto. Justicia constitucional y derechos fundamentales. op. cit. p. 103. Saliento que nessa passagem o jusfilósofo de Toledo emprega o vocábulo constitucionalismo para caracterizar o fenômeno do neoconstitucionalismo.

${ }^{68}$ SERNA, Pedro. "Prefácio". In: CRUZ, Luis M. La Constitución como orden de valores, problemas jurídicos y políticos: un estudio sobre los orígenes del neoconstitucionalismo. Granada, Editoral Comares, 2005, p. XVIII e XIX. 
soluções aos impasses gerados no paradigma dominante no campo do direito, o positivismo jurídico com suas diversas versões, a partir da evolução contemporânea do direito constitucional e das correlatas empresas teóricas de Dworkin, Alexy e Nino.

\title{
II. O neoconstitucionalismo em seus três aspectos
}

Ainda no esforço de circunscrever esta nova configuração do pensamento teórico, sirvo-me da precisa delimitação elaborada por Tecla Mazzarese, ao identificar três possíveis sentidos de neoconstitucionalismo, e arrolada por Susana Pozzolo em seu artigo "Um constitucionalismo ambíguo". Peço desculpas ao leitor pela extensão da citação, mas seria difícil elaborar síntese tão precisa:

\begin{abstract}
[Há] três possíveis sentidos de 'neoconstitucionalismo': a) em um primeiro sentido, 'neoconstitucionalismo' indicaria um traço caracterizador de alguns ordenamentos jurídicos: em particular, o dado positivo pelo qual o ordenamento apresenta uma Constituição que, além de conter as regras de individualização e ação dos órgãos principais do Estado, apresenta um mais ou menos amplo elenco de direitos fundamentais; b) em um segundo sentido, 'neoconstitucionalismo' indica um certo modelo explicativo do conteúdo de determinados ordenamentos jurídicos (os indicados no ponto precedente), ou seja, o termo indicaria um certo paradigma do Direito, de sua forma de aplicação e de conhecimento; nesse segundo sentido 'neoconstitucionalismo' não indica portanto nada no mundo, senão que mais precisamente representa um modelo teórico; c) em um terceiro sentido, o termo 'neoconstitucionalismo' indicaria um modelo axiológico-normativo do direito, um modelo ideal ao qual o Direito positivo deveria tender. Esse ideal, sem embargo, não seria um 'objeto' externo e separado do Direito concreto, senão pelo contrário seria um mero desenvolvimento e a mera concretização do Direito real, sobre a base dos princípios e dos valores que em este último estão expressamente enunciados. ${ }^{69}$
\end{abstract}

Seguindo esta tripartição supra citada gostaria de detalhar melhor esses três sentidos da categoria neoconstitucionalismo (como salientado na introdução deste trabalho). Acompanhando o magistério de Prieto Sanchís (tais distinções se encontram no texto "Sobre o neoconstitucionalismo y sus implicaciones", incluído no livro Justicia Constitucional e Derechos Fundamentales), pode-se afirmar que no primeiro sentido entendemos o neoconstitucionalismo como um certo tipo de Estado de direito caracterizando uma determinada forma de organização política. No segundo sentido, entende-se como uma teoria do direito que serve para descrever esse modelo. No terceiro sentido, uma filosofia política ou ideologia que justifica esse modelo. Esclareço que essa tripartição funciona a par da já canônica classificação utilizada Comanducci, inspirada em Bobbio, distinguindo o neoconstitucionalismo teórico do ideológico e do metodológico. ${ }^{70}$

\footnotetext{
${ }^{69}$ MAZZARESE, Tecla. Appunti del corso di filosofia del diritto, anos 2000/2001, proferido na Faculdade de Jurisprudência da Universidade de Brescia, inédito, apud POZZOLO, Susana. "Um constitucionalismo ambíguo". In: Neoconstitucionalismo(s), opus cit. p.178 e 179.

${ }^{70}$ Essa divisão foi exposta originalmente no texto "Formas de (neo)constitucionalismo: un análisis metateórico". In: Isonomia, n. 16 (2002), p. 89-112, posteriormente publicado, na íntegra, no livro Neoconstitucionalismo(s). Neste texto, temos uma das melhores caracterizações do fenômeno da constitucionalização do direito. Como afirma o autor, na página 95: "No ordenamento jurídico italiano, também e sobretudo a partir das deliberações da Corte constitucional, produziu-se uma progressiva 'constitucionalização' do direito. Trata-se de um processo ao fim do qual o direito é 'impregnado', 'saturado' ou 'embebido' pela Constituição: um direito constitucionalizado se caracteriza por uma constituição invasiva,
} 


\section{II.1. Como teoria do Estado}

Em relação ao primeiro sentido, cabe destacar que alterou-se, no final do século passado, a dimensão assumida pelos textos constitucionais em certos ordenamentos jurídicos, rompendo com a tradição liberal oitocentista. As mudanças se dão sobretudo graças ao caráter axial assumido pelos direitos fundamentais, constituindo estes “(...) a razão de ser do Estado de Direito, sua finalidade mais radical, o objetivo e critério que dá sentido aos mecanismos jurídicos e políticos que o compõem." "71. O constitucionalismo do pósguerra modificou uma visão tradicional mais limitada acerca da função da Lei Maior nas estruturas jurídicas hodiernas, fazendo com que "o direito não [seja] (A.M.) visto somente como um meio de proteção dos direitos individuais, mas como uma expressão da prática comum de uma comunidade política."72 Novamente, os modelos das experiências alemã e italiana e das constituições ibéricas somam razões à constatação que qualquer observador pode fazer acerca do redimensionamento da função da Constituição desempenhada, em nosso país, pela Carta de 1988, vis-à-vis sua antecessora, de 1967/69.

Quanto ao novo papel representado pela Constituição, afirma Lenio Streck: "no moderno constitucionalismo, uma das conquistas reside exatamente na nova configuração da relação entre os poderes do Estado. A renovada supremacia da constituição vai além do controle de constitucionalidade e da tutela mais eficaz da esfera individual de liberdade.

Com as Constituições democráticas do século XX, outro aspecto assume lugar cimeiro: trata-se da circunstância de as Constituições serem erigidas à condição de norma diretiva fundamental, que se dirige aos poderes públicos e condiciona os particulares de tal maneira que assegura a realização dos valores constitucionais (direitos sociais, direito à educação, à subsistência, à segurança, ao trabalho etc). A nova concepção de constitucionalidade une precisamente a ideia de Constituição como norma fundamental de garantia com a noção de Constituição enquanto norma diretiva fundamental."73 Assim, reconhece-se uma mudança de natureza no papel desempenhado por certas constituições em determinados sistemas jurídicos avançados.

Quem também explica com precisão essas transformações ocorridas em certos sistemas jurídicos contemporâneos, nestas últimas décadas, é Elias Díaz ${ }^{74}$ quando destaca: "É verdade que no passado, em geral de maneira não expressa, tendia-se com excessiva frequência e simplicidade (interessada?) a definir de modo redutivo a Constituição com um caráter quase meramente programático, quer dizer, não prescritivo, não (mais ou menos) diretamente normativo. Frente a tais reduções, o entendimento atual da Constituição como norma jurídica, com todas as mediações e reservas que a prudência (inclusive a

\footnotetext{
que condiciona a legislação, a jurisprudência, a doutrina e os comportamentos dos atores políticos. Trata-se, ademais, de um conceito graduado: um direito pode ser mais ou menos constitucionalizado."

${ }^{71}$ DÍAZ, Elias. "Filosofia del Derecho: Legalidad-legitimidad”. In: MUGUERZA, Javier e CEREZO, Pedro (ed.). La Filosofía Hoy. Barcelona, Editorial Crítica, 2000, p. 323.

${ }^{72}$ BAYNES, Kenneth. "Deliberative Democracy and the Limits of Liberalism". In: VON SCHOMBERG, René e BAYNES, Kenneth. (ed.) Discourse and Democracy - Essays on Habermas's Between Facts and Norms. New York, State University of New York, 2002, p. 16.

${ }^{73}$ STRECK, Lenio Luiz. "Os Juizados Especiais Criminais à Luz da Jurisdição Constitucional. A Filtragem Hermenênutica a Partir da Aplicação da Técnica da Nulidade Parcial sem Redução de Texto". In: Revista da EMERJ, v. 6, n. 24. Rio de Janeiro, EMERJ, 2003, p. 110.

${ }^{74}$ DÍAZ, Elias. "Filosofia del Derecho: Legalidad-legitimidad", op. cit, p. 320.
} 
jurisprudência) autorize ou permita introduzir, parece-me uma conquista a todas luzes muito positiva e completamente coerente com o melhor Estado de Direito". Assim, na esteira do que leciona o jusfilósofo espanhol, pode-se compreender que as mudanças operadas na doutrina contemporânea - como, por exemplo, o desenvolvimento do paradigma neoconstitucionalista - convergem no esforço de garantir uma normatividade mais plena do texto constitucional.

Cabe destacar um aspecto importante ligado a esse primeiro sentido de neoconstitucionalismo: ele está referido não só ao fato de que certas formações jurídicas apresentam uma determinada estrutura constitucional ${ }^{75}$ - uma constituição rígida, com a sua garantia jurisdicional, reconhecendo a forma vinculante da Lei maior e atenta ao fenômeno da sobre-interpretação da Constituição etc -, como ao fato de que assistimos a uma "rearticulação" da tradicional forma de encarar a divisão dos poderes. É indiscutível, em tempos de neoconstitucionalismo, o crescente protagonismo do Judiciário, em especial das Cortes Constitucionais. Miguel Carbonell, na introdução da obra de referência deste debate, salienta que nesse novo modelo há uma forte "impregnação judicialista". (Quanto a essa reconfiguração do papel do Judiciário, serão tecidas algumas considerações na conclusão deste trabalho)

\section{II.2. Como teoria do direito}

Em relação ao segundo sentido, importa destacar, de início, que as democracias constitucionais nas últimas décadas parecem demandar uma nova teoria do direito que vá além dos moldes positivistas. Nesta nova teoria do direito a interpretação constitucional e a teoria da argumentação jurídica se imbricam. No contexto de uma Constituição rematerializada, conformada por princípios, valores, direitos fundamentais e diretrizes de denso conteúdo normativo - uma constituição onipresente, que se pretende vinculante e eficaz em todas as áreas jurídicas, inclusive nas relações horizontais de direito privado - a tarefa de aplicação da lei supõe um esforço de interpretação e argumentação especialmente refinado. Os métodos tradicionais de resolução de conflitos normativos já não são suficientes. As decisões judiciais dependem de argumentos complexos, exigem decisões envolvendo princípios que vão além do uso do esquema lógico-dedutivo, e requerem também por parte do juiz o uso da racionalidade teleológica. Assim, o constitucionalismo alicerçado em princípios e direitos parece exigir que os juízes, ao se depararem cada vez mais com "casos difíceis", se tornem filósofos (Dworkin) e, além disso, dominem complexas técnicas de ponderação de bens e valores.

A descrição acima elaborada enseja condições que impõem a construção de uma nova teoria do direito elaborada basicamente por "filósofos do Direito com vocações para constitucionalistas e de constitucionalistas com vocações para filósofos do Direito"76. A

\footnotetext{
${ }^{75}$ Sigo, obviamente, como não poderia deixar de ser, o entendimento de Riccardo Guastini no seu texto "La ‘constitucionalización' del ordenamiento jurídico: el caso italiano”. In: CARBONELL, Miguel (org). Neoconstitucionalismo(s), op. cit., p. 49-73.

${ }^{76}$ FIGUEROA, Alfonso García."La teoria del derecho em tiempos de constitucionalismo". In: CARBONELL, Miguel (org.) Neoconstitucionalismo(s), op. cit., p. 159 - 186. No mesmo texto mapeia o quadro de uma série de autores que convergem em direção ao paradigma do 'constitucionalismo', do 'Estado constitucional de direito' ou do neoconstitucionalismo; o denominador comum se situa em um esforço de se colocar para além do confronto entre jusnaturalismo e positivismo. Assim, afirma, na página 161, que, "esta concepção colabora às vezes com uma pujante teoria da argumentação jurídica e moral (Alexy), e em outras se acha presidida pelo
} 
demanda de uma nova teoria, alicerçada no entrecruzamento dessas duas disciplinas supramencionadas, evidencia-se quando pensamos, por exemplo, em um dos âmbitos centrais do debate justeorético contemporâneo: a estrutura das normas de direitos fundamentais. Posso sublinhar que tal questão implica dilucidar a distinção entre regras, princípios e valores. Tais indagações são centrais para a filosofia jurídica e para o direito constitucional: a distinção entre regras e princípios (e, por exemplo, a questão acerca do status dos princípios jurídicos: devem ser entendidos como mandados de otimização ou como enunciados deontológicos?) e a distinção entre princípios e valores apresentam notável dificuldade. Atualmente, torna-se impossível abordar o estudo da natureza profunda das normas sobre direitos fundamentais sem assumir uma posição sobre essas dicotomias - as quais nos levam à referência ao neoconstitucionalismo como paradigma jurídico, já que neste tais distinções adquirem máxima relevância. $\mathrm{O}$ neoconstitucionalismo representa um paradigma jurídico em formação que, entre outras coisas, reformula o problema clássico do conceito de direito e de seu valor moral a partir da análise de dois questionamentos: a carga axiológica do direito nos Estados constitucionais ${ }^{77}$ e o funcionamento e a estrutura particulares das normas sobre direitos fundamentais.

Tal problemática deixa patente aquilo que se tornou um lugar comum dos estudos jurídicos hodiernos: o estreito liame entre filosofia do direito e direito constitucional - posto que considerações constitucionais desempenham papel central no âmbito da filosofia do direito. Um outro eloquente exemplo da vinculação entre filosofia do direito e direito constitucional se dá quando se adota uma “(...) postura 'constitucionalista' em lugar da 'legalista estrita', isto é, a ponderação revela-se, sem a menor dúvida, mais significativa do que a subsunção para o intérprete constitucional." ${ }^{78}$ Ora, se para o constitucionalista contemporâneo a ponderação é crucial, posto que não há rol de direitos fundamentais sem colisão destes mesmos direitos - como os incontornáveis conflitos entre liberdade e segurança, honra e liberdade de expressão, vida e autonomia pessoal etc. -, impõe-se a demanda constante por ponderação. Tal mecanismo só pode ser empregado de maneira racionalmente controlável se seguir os cânones ditados pelas modernas teorias da argumentação jurídica - campo por excelência dos desenvolvimentos jusfilosóficos recentes, sem o qual não seria possível a proposta de um novo paradigma como o neoconstitucionalista -, afinal, o deslocamento em relação aos paradigmas jusnaturalista e positivista encontra apoio no forte desenvolvimento experimentado pelas teorias da argumentação jurídica nas últimas décadas - desenvolvimento esse propiciador de um quadro de referência teórico capaz de parametrizar tanto a aplicação dos princípios, como o alargamento da latitude discricional garantida aos magistrados dentro do cenário jurídico hodierno.

\footnotetext{
ideário garantista (Ferrajoli), frequentemente incorpora as objeções (Dworkin) e as correções (Coleman, Walluchov) ao positivismo hartiano e quase sempre encontra respaldo entre teóricos dos direitos fundamentais (Peces-Barba) e a dogmática constitucional (Gustavo Zagrebelsky)".

${ }^{77}$ Essa questão, que não poderá ser tratada aqui a contento, implica um novo conceito de direito, como o elaborado por Robert Alexy, apontando para uma dupla natureza do direito. Tal característica "consiste na união do aspecto institucional e autoritativo com o ideal e crítico". Cf. ATIENZA, Manuel. "Entrevista a Robert Alexy”. In: Doxa, n. 24, 2001, p. 671.

${ }^{78}$ FREITAS, Juarez. "O Intérprete e o Poder de Dar Vida à Constituição: Preceitos de Exegese Constitucional". In: GRAU, Eros Roberto e GUERRA FILHO, Willis Santiago (org.). Direito Constitucional.
} 
A necessidade desta nova teoria impõe-se a partir da mudança de compreensão do papel do texto constitucional operada na Europa depois da segunda guerra mundial. Como salienta Letizia Gianformaggio:

\begin{abstract}
Graças (...) a descoberta de que a Constituição é uma verdadeira norma jurídica que começou a se transformar a ideia de que os juristas faziam deles mesmos; é a partir disto que uma certa autorrepresentação morreu. O que se transformou foi a ideia de que os juristas, teóricos ou práticos, tinham de seu lugar dentro do sistema jurídico e que eles tinham da antiga tradição do positivismo jurídico. Esta se fundava sobre a noção da toda potência do legislador, da centralidade da lei, notadamente dos códigos, ou da ideia de que a interpretação dentro do processo de aplicação do direito apresentava uma dimensão simplesmente cognitiva e portanto a-avaliativa ${ }^{104}$.
\end{abstract}

Correndo o risco de desviar um pouco do desenvolvimento lógico da argumentação deste texto - com a explicitação do segundo sentido do neoconstitucionalismo -, importa salientar, que com a constitucionalização do direito, constata-se que, através dos direitos fundamentais e de sua capacidade de irradiação pelo ordenamento jurídico, tem-se um dos exemplos mais eloquentes de um mecanismo de garantia da efetivação dos impulsos emancipatórios, oriundos do pensamento político moderno e transpostos para os textos constitucionais hodiernos. Tais impulsos emancipatórios, de virtualidades reconhecidas no âmbito normativo, podem vir a ser paulatinamente concretizados por políticas públicas consequentes e uma hermenêutica progressista. Desta forma, "a materialização política do sistema de direitos é uma práxis que se leva a cabo segundo os critérios e pelas vias do sistema de direito já existente. As mesmas normas constitucionais estabelecem o procedimento segundo o qual elas mesmo se 'concretizam' à luz das circunstâncias cambiantes." $" 105$

No tocante à teoria do direito neoconstitucionalista, deve-se assinalar uma diferença significativa em relação ao papel do cientista do direito como pensada no quadro do pensamento jurídico Novecentista (vale dizer, predominantemente de corte positivista). Correlata ao abandono do postulado positivista da análise avalorativa do direito - posto que a teoria neoconstitucionalista assume um caráter prático, visando fornecer aos operadores

Estudos em homenagem a Paulo Bonavides. São Paulo, Malheiros Editores, 2001, p.231. Neste mesmo diapasão, a constitucionalista portuguesa Cristina M. M. Queiroz afirma: “o instrumento decisivo do 'método' de interpretação constitucional não é já a subsunção, mas a retórica e o argumento." (grifo no original) QUEIROZ, Cristina M. M. Direitos fundamentais (Teoria Geral). Coimbra, Coimbra Editora, 2002, p. 184. 104

GIANFORMAGGIO, Letizia. "Prefácio". In : SCARPELLI, Uberto. Qu'est - ce que le positivisme juridique?. Paris, Bruylant L.G.D.J, 1996, p. VI.

105 HABERMAS, Jürgen. Verdad y justificación. Ensayos filosóficos. Madrid, Editorial Trotta, 2002, p.

61.

jurídicos as melhores soluções aos problemas suscitados pela práxis dos tribunais -, a distinção entre prescrição e descrição ${ }^{79}$ (cuja problemática já foi abordada no inicio deste

\footnotetext{
${ }^{79}$ Para uma apresentação da distinção entre juízos de fato e juízos de valor, correlata a distinção entre prescrição e descrição confira-se o texto "A distinção entre fatos e valores e as pretensões neofrankfurtianas". In: MAIA, Antonio Cavalcanti. Jürgen Habermas: filósofo do direito, op. cit., p. 135-173; importa frisar que o modo como a ética do discurso enfrenta este venerável problema da filosofia, com a proposta de um pragmatismo kantiano, abre uma perspectiva epistemológica capaz de situar a reflexão teórica para além do balizamento acatado pelos diversos positivismos. Sem este "pressuposto" filosófico, perderia a credibilidade a proposta matriz do neoconstitucionalismo não positivista de Robert Alexy.
} 
trabalho) não constitui mais um dado incontornável. Tal distinção - e o respeito escrupuloso ao hiato epistemológico por ela ensejado - constitui um elemento central da concepção positivista de ciência do direito. Entretanto, questiona-se este posicionamento dentro da concepção neoconstitucionalista, já que, neste modelo, como salienta Sastre Ariza, “(...) se insiste que a função descritiva não só é uma autêntica limitação da dogmática, que deve comprometer-se com a resolução de problemas práticos, mas (...) que as descrições também serviram para camuflar, em certas ocasiões, juízos de valor." Como também afirma Ariza e parece ser, dentro dos textos coletados na obra de referência Neoconstitucionalismo(s), o teórico mais atento a essa importante questão filosófica, que tem relação com os próprios pressupostos epistemológicos do trabalho científico, agora entendidos de maneira diferente daqueles do início do século XX - , "a presença nas constituições de standards de moralidade, que podem chegar a colidir em sua aplicação a casos concretos, tem contribuído poderosamente para dificultar a tarefa de saber qual é o conteúdo das disposições jurídicas e, portanto, a duvidar que a descrição possa ser o último reduto da pureza que deve presidir a atuação da ciência jurídica." 80

Esse distinto enfoque acerca do âmbito de competência da teoria do direito nos nossos dias também é objeto das reflexões de Albert Calsamiglia. Embora o autor não se inclua na corrente neoconstitucionalista (e se a morte não tivesse tão cedo calado uma das principais vozes da teoria do direito contemporânea, provavelmente ele se posicionaria acerca desse novo paradigma), em sua démarche, há a clara defesa da superação do postulado positivista da separação absoluta entre descrição e prescrição, como já destacado na primeira parte deste trabalho. Portanto há a recusa em aceitar como axioma a distinção nuclear do positivismo - quer seja jurídico ou sociológico - entre descrição e prescrição.

Desta forma "o pós-positivismo jurídico [e o neoconstitucionalismo, A.C. Maia ${ }^{81}$ ] é marcado por um abrandamento da distinção entre enunciados de lege ferenda recomendações justificadas para o legislador $-\mathrm{e}$ enunciados de lege latta descrição/conhecimento do direito vigente - , com repercussões diretas para a dogmática jurídica, a quem é atribuída a função de produzir coerência para o direito" ${ }^{\text {"2 }}$. Em especial nos casos difíceis, o trabalho doutrinário procura lançar pontes entre a teoria e a prática, municiando os operadores do direito com instrumentos capazes de conduzi-los a respostas pertinentes para os problemas jurídicos, bem fundadas e ao mesmo tempo verificáveis e, na medida do possível, objetivamente controláveis. E essa controlabilidade é garantida pela argumentação jurídica, daí o papel crucial das teorias-padrão da argumentação jurídica, de Alexy e MacCormick, nessa nova configuração teórica.

Em relação a essa problemática, como afirma Calsamiglia (e já destacado no início deste trabalho), a teoria não só descreve, mas também forma parte do direito; o jusfilósofo de Barcelona salienta que o pensamento jurídico tem a função de reduzir a incerteza do direito. Para ele, seguindo Dworkin, tem-se "[que ele] considera que toda teoria jurídica

\footnotetext{
${ }^{80}$ ARIZA, Santiago Sastre. "La ciencia jurídica ante el neoconstitucionalismo", op. cit, p.250.

${ }^{81}$ Quanto ao desenvolvimento da perspectiva de análise de Thomas da Rosa Bustamante de seu livro Argumentação contra legem. A teoria do discurso e a justificação jurídica nos casos mais difíceis. Rio de Janeiro, Renovar, 2005, para uma posição que endossa a démarche neoconstitucionalista veja-se a segunda parte de seu livro "Um debate sobre o neoconstitucionalismo". In: Teoria do direito e decisão racional. Temas de teoria da argumentação jurídica; op. cit. p. 141-215.

${ }^{82}$ BUSTAMANTE, Thomas da Rosa de. Argumentação contra legem. A teoria do discurso e a justificação jurídica nos casos mais difíceis. Op. cit. p. 35.
} 
deve ter um aspecto descritivo e outro aspecto prescritivo. A teoria não só serve para conhecer o direito vigente mas também é um auxiliar indispensável para o juiz. Dworkin destrói o suposto metodológico positivista da separação absoluta entre a descrição e a prescrição. Em um caso difícil a teoria é o fundamento da validade da tese da resposta correta. Sem uma teoria do direito não é possível solucionar os casos difíceis. O juiz ao utilizar a teoria como critério para a resolução aplica o direito. A teoria não somente descreve mas forma parte do direito." ${ }^{\prime 83}$ (Neste momento não posso explicitar como gostaria a tese que agora afirmo: o pós-positivismo, como entendido por Calsamiglia, sinaliza uma transição entre o paradigma positivista e este novo cenário aberto no início do nosso milênio pelo neoconstitucionalismo. Já na década de 90, em diversos textos, Calsamiglia sinaliza a erosão do quadro teórico positivista em face das mudanças ocorridas tanto no quadro legal com o proeminente papel dos princípios jurídicos nas constituições contemporâneas - , como no front teórico com a obra de Ronald Dworkin. Saliente-se que Calsamiglia desenvolveu um trabalho mais focalizado na interface do pensamento jusfilosófico espanhol com o anglo-saxônico, enquanto os propugnadores do neoconstitucionalismo não positivista como Figueroa - empenham-se em estreitar as reflexões da doutrina espanhola com as culturas jurídicas alemã - Alexy sobretudo - e italiana - Zagrebelsky e Ferrajolli.)

Enfim, essas considerações procuraram apresentar, ainda de forma preliminar, algumas das principais especificidades da abordagem neoconstitucionalista entendida como uma teoria do direito. Depreende-se do ora exposto que tal paradigma exige dos juristas uma posição mais ativa e comprometida com a melhor realização do Estado constitucional democrático de direito. Tal posicionamento parte também de um pressuposto importante, qual seja, uma confiança na possibilidade de os sistemas jurídicos contemporâneos - em especial aqueles dotados de textos constitucionais caracterizados por longos catálogos de direitos fundamentais - servirem como escoadouro para os inúmeros problemas presentes nas complexas sociedades contemporâneas. Subjaz ao modelo de teoria do direito neoconstitucionalista uma apreciação mais positiva acerca do papel do direito nas sociedades contemporâneas - distante tanto das reprovações tradicionais do marxismo quanto da desconfiança pós-moderna. ${ }^{111}$ Tais considerações levam a refletir sobre a outra dimensão da categoria neoconstitucionalismo, isto é, o entendimento desse paradigma também como uma ideologia ou filosofia política.

\section{II.3. Como filosofia política}

Em relação ao terceiro sentido do termo neoconstitucionalismo, deve-se atentar para o fato de que ele pressupõe "fundamentos filosófico-políticos, quero dizer, normativos" ${ }^{84}$. E essa dimensão filosófico-normativa deve ser entendida sob dois aspectos: um no âmbito da filosofia política e outro no campo do debate ético.

No domínio da filosofia política, a discussão acerca desse terceiro sentido se dá no debate relativo às formas de legitimação das estruturas jurídicas contemporâneas; encontrase

\footnotetext{
${ }^{83}$ CASAMIGLIA, Albert. "Ensayo sobre Dworkin”. In: Los Derechos en serio, Barcelona, Ariel, 1997, p. 16. 111 Quanto a esta mudança na compreensão acerca do papel do direito, a partir da perspectiva de Habermas, confira-se o texto "Considerações acerca do papel civilizatório do direito". In: MAIA, Antonio Cavalcanti. Jürgen Habermas: Filósofo do direito. Rio de Janeiro, Renovar, 2008, p. 1-29.

${ }^{84}$ MORESO, José Juan. "Comanducci sobre neoconstitucionalismo”. In: Isonomia, n 19, outubro 2003.
} 
aqui, também, uma das novidades do cenário teórico contemporâneo - ensejadora de um quadro favorável à emergência de um novo paradigma jurídico: o crescente diálogo entre filosofia política e teoria constitucional, tendo como autores de referência Jürgen Habermas e John Rawls. Assim, o teórico do direito vê-se envolvido num debate relativo a questões como o ressurgimento do republicanismo, a plausibilidade da doutrina do patriotismo constitucional, a relação entre ordem jurídica e teorias da justiça etc. No tocante ao patriotismo constitucional, Prieto Sanchis aponta para uma diferença entre essa ideia e o neoconstitucionalismo como filosofia política:

(...) gostaria de advertir agora que, assim entendida, a filosofia política constitucionalista não é necessariamente equivalente ao chamado patriotismo constitucional, tão debatido nos últimos tempos. Àquela alude a uma certa forma de organizar o Estado de Direito que apresenta algumas peculiaridades em respeito ao modelo liberal clássico e, em especial, ao comprometimento da lei a um Direito Superior; o patriotismo, por sua vez, me parece consistir em fazer a própria Constituição um elemento de adesão e integração política e social complementando o substituto de outras ideias mais amenas, como a ideia de nação. Se tratam em ambos os casos de ideologias porém com significados e funções diferentes. ${ }^{85}$

Por outro lado, há quem sustente - e me situo claramente dentro deste posicionamento ${ }^{86}$ uma frutífera convergência entre o neoconstitucionalismo e o patriotismo constitucional. Nesse sentido, afirma Gloria Lopera Mesa:

O neoconstitucionalismo também se manifesta como uma ideologia, isto é, uma filosofia política que concebe o Estado Constitucional como um marco justo para o exercício do poder e, a partir dela, alguns autores sustentam que, ao menos nos sistemas políticos que se ajustam ao dito modelo, é plenamente justificável uma obrigação de obediência ao direito. A vertente ideológica do neoconstitucionalismo se vê fortalecida por uma forte carga axiológica e a dimensão dirigente presente nos textos constitucionais, concebidos como elementos geradores de consenso e dinamizadores de um 'patriotismo constitucional' que nas atuais sociedades pluralistas e multiculturais do ocidente vêm a suprir o recurso à ideia de nação. ${ }^{115}$

No âmbito normativo, deve ser destacado um outro aspecto, concernente ao neoconstitucionalismo não-positivista - no qual reside o diferendo em face dos diversos positivismos-: a problemática da razão prática, isto é, razão que “(...) consiste em um conjunto de argumentos que justificam proferimentos prescritivos ou normativos,

\footnotetext{
${ }^{85}$ PRIETO SANCHÍS, Luis. Justicia constitucional y los derechos fundamentales. op.cit.

${ }^{86}$ Em relação à temática do patriotismo constitucional, em língua portuguesa cf: LACROIX, Justine.

"Patriotismo constitucional e identidade pós-nacional em Jürgen Habermas". In: ROCHLITZ, Rainer.

Habermas: O uso público da razão. Rio de Janeiro, Tempo Brasileiro, 2005. MAIA, Antonio Cavalcanti. "Diversidade cultural, identidade nacional brasileira e patriotismo constitucional", In: LOPES, Antonio Herculano e CALABRE, Lia (org.). Diversidade cultural brasileira. Rio de Janeiro, Edições Casa de Rui Barbosa, 2005. OLIVEIRA, Marcelo Andrade Cattoni. Poder constituinte e patriotismo constitucional. Belo Horizonte, Mandamentos, 2006. BUNCHAFT. Maria Eugenia. O patriotismo constitucional na perspectiva de Jürgen Habermas: A reconstrução da ideia de nação na filosofia política contemporânea. Rio de Janeiro, Lumen Juris, 2010. Na literatura internacional, a quantidade de textos publicados em revistas sobre a temática do patriotismo constitucional é enorme. Recentemente foi publicada obra monográfica do cientista político alemão, professor de Princeton, Jan-Werner MÜLLER. Constitutional Patriotism. Princeton, Princeton University Press, 2007. 115 MESA, Gloria Patrícia Lopera. La aplicación del derecho en los sistemas jurídicos constitucionalizados. Medelin, março de 2004, p.20 (mimeo).
} 
preferências, julgamentos de valor ou normas. ${ }^{, 87}$ Neste particular, temos o núcleo filosófico das divergências entre neoconstitucionalismo não positivista e as doutrinas positivistas, que, em muitos $\operatorname{casos}^{88}$, não atentam para as significativas transformações observadas no panorama do debate de meta-ética contemporânea, onde as éticas cognitivistas construtivistas de matriz kantiana - quer seja na sua vertente anglo-americana com Rawls, Dworkin e Santiago Nino ou na vertente alemã da teoria discursiva do direito e da democracia - elevaram o debate ético a um patamar pós-metafísico.

Sendo assim, tanto Habermas quanto Alexy podem sair dos impasses presentes nas antinômicas posições do postivismo ceticista e da ética material dos valores de Max Scheler e Nicolai Hartmann - ambas as correntes extremamente influentes nos domínios jusfilosófico e de teoria constitucional - oferecendo uma via média ao decisionismo das primeiras correntes (adeptas de um naturalismo cientificista irrefletido) e ao absolutismo das segundas (carregadas de concepções metafísicas incompatíveis com o atual cenário do pensamento contemporâneo). Afinal, o procedimento, dentro da teoria discursiva do direito, identifica uma espécie de racionalidade formal, a única que pode dar conta do campo das normas, dos deveres e dos valores; e tal procedimento se alicerça em uma ética minimalista - a ética do discurso.

Quanto a Dworkin (inspirado fortemente em John Rawls neste aspecto) observa-se que o jusfilósofo estadunidense, na justificação dos princípios e direitos fundamentais, não lança mão de construções metafísicas, ou a fundamenta na crença na existência de uma moral objetiva. Dworkin toma por base o construtivismo rawlsiano e, através de uma reconstrução teórica, emprega a noção de equilíbrio reflexivo como uma forma de relacionar nossas intuições morais em um conjunto articulado de proposições que poderiam integrar nossas teses em um todo coerente, dando-lhes sentido e racionalidade. Tais intuições - como as ideias de tolerância, liberdade e igualdade - encontram-se formuladas nos princípios fundamentais que dão base às instituições concretamente vigentes no mundo ocidental e a sua defesa é capaz de resistir à discussão objetiva e racional.

III - Neoconstitucionalismo: notas sobre Ensayos Escogidos.

\footnotetext{
${ }^{87}$ LA TORRE, Massimo. "Theories of Legal Argumentation and Concepts of Law. An Approximation". In: Ratio Juris. Vol. 15. n. 4. Oxford, Blackweel Publishers, dezembro de 2002.

${ }^{88}$ Como, por exemplo, Pierre Brunet, que na parte relativa à análise crítica de seu texto afirma uma impropriedade teórica ao comparar os pressupostos ético-filosóficos do neoconstitucionalismo com o racionalismo ético do século XVII: “(...) a teoria do direito defendida pelo neoconstitucionalismo retoma esta mesma antífona [do racionalismo ético do século XVIII, AC Maia] de um fundamento absoluto do direito e do poder." BRUNET, Pierre. "Le droit est-il obligatoire? La response positiviste à traver une analyse critique du Neoconstitucionalisme" In : Le droit de résistance à l'opression. Actes du colloque de Dijon (decembre 2002) D. Gros et O. Camu (dir.). Paris, Seuil, Le genre humain, 2005, p. 251. Como falar de fundamento absoluto quando o solo filosófico sobre o qual se ergue o constitucionalismo é dado pelas propostas filosóficas de John Rawls e Karl-Otto Apel e Jürgen Habermas, situando-se no âmbito do pensamento pós-metafísico e adotando abordagens construtivistas - como é também, nesse último aspecto, o traço epistemológico central de um dos nomes do neoconstitucionalismo, Carlos Santiago Nino. Uma outra crítica, formulada por Mauro Barberis, ignora também que o neoconstitucionalismo, estribado nos projetos filosóficos antes indicados, situa-se para além dos pressupostos webero-kelsenianos - com a assunção do irredutível pluralismo de valores - e aposta na competência da razão humana para lidar com o conflituoso mundo das opções normativas. Quanto ao pensamento do jusfilósofo italiano, cf. "Neoconstitucionalismo, democracia e imperialismo de la moral". In: CARBONELL, Miguel (org.). Neoconstitucionalismo(s), op. cit, p. 277.
} 
A ciência jurídica não tem uma função meramente contemplativa de seu objeto de estudo, mas contribui de forma decisiva a criá-lo e, nesse sentido, se constitui como uma espécie de meta-garantia do ordenamento jurídico em seu conjunto.

Luigi Ferrajoli

Em 2007, foi publicado o livro Neoconstitucionalismo. Ensayos escogidos, que sinaliza para uma consolidação deste debate (no primeiro livro, como afirma Carbonell ${ }^{89}$, foram apresentados os postulados desse novo quadro geral de referencias; no segundo, como esses postulados se aplicam diante dos problemas). $\mathrm{O}$ organizador chama a atenção para $\mathrm{o}$ fato de "o neoconstitucionalismo, entendido como um termo ou conceito que explica um fenômeno relativamente recente dentro do Estado constitucional contemporâneo, parece contar cada dia com mais seguidores, sobretudo no âmbito da cultura jurídica italiana e espanhola, assim como em diversos países da América Latina ${ }^{119}$ (particularmente nos grandes focos culturais da Argentina, Brasi1 ${ }^{90}$, Colômbia e México)." 91

Observa também Carbonell que alguns autores se perguntam se na realidade existe algo de novo no neoconstitucionalismo ou se seria apenas uma etiqueta vazia, que serve para apresentar uma nova roupagem de questões que até então eram explicadas de outra maneira. Existem, como destaca, ao menos, três níveis de análise que convém considerar:

I) Textos constitucionais: Constituições que não se limitam a estabelecer competências ou separar os poderes públicos, senão que contêm altos níveis de normas materiais ou substantivas que condicionam a atuação do Estado por meio da ordenação de certos fins e objetivos.

II) Práticas jurisprudenciais: os juizes constitucionais tiveram que aprender a realizar sua função dentro de parâmetros interpretativos novos, a partir dos quais a racionalidade judicial se faz mais completa. Entram em jogo as técnicas próprias dos

\footnotetext{
${ }^{89}$ CARBONELL, Miguel. "El Neoconstitucionalismo em su laberinto". In Teoria del neoconstitucionalismo. Ensayos escogidos, op. cit. 119 Como salienta um arguto orientador europeu: “"Neoconstitucionalismo” é um rótulo que, pelos finais dos anos noventa do século passado, uns integrantes da escola genovesa de teoria do Direito (Susanna Pozzolo, Mauro Barberis e eu mesmo) começaram a utilizar para classificar e criticar algumas tendências póspositivistas da filosofia jurídica contemporânea, que apresentam características comuns, mas também diferenças entre si. O rótulo tem tido muito êxito, mas acima de tudo têm multiplicado, na Europa (particularmente na Espanha e Itália) e América Latina (particularmente na Argentina e México), os estudos dessas tendências e sua comparação com o positivismo jurídico.” COMANDUCCI, Paolo; AHUMADA, Maria Ángeles; LAGIER, Daniel González. Positivismo jurídico y neoconstitucionalismo. Madrid, Fundación Colóquio Jurídico Europeo, 2009, p. 87.

${ }^{90}$ Para uma apurada apresentação do neoconstitucionalismo em nosso país, em livro que já é referência internacional sobre o assunto, veja-se MOREIRA, Eduardo Ribeiro. Neoconstitucionalismo: a invasão da Constituição. São Paulo, Editora Método, 2008. A abordagem do constitucionalista e jusfilósofo está em sintonia com as teses aqui sustentadas, bem como com a posição de Alfonso Garcia Figueroa.

${ }^{91}$ CARBONELL, Miguel. "El Neoconstitucionalismo em su laberinto". In: Teoria del neoconstitucionalismo. Ensayos escogidos. Madrid, Editorial Trotta, 2007, passim.
} 
Quaestio Iuris

vol.04, n0.01. ISSN 1516-0351

princípios constitucionais: ponderação, razoabilidade, maximização dos efeitos normativos dos direitos fundamentais, irradiação horizontal. Dificuldade de trabalhar com valores. 
III) Desenvolvimentos Teóricos: partem do texto constitucional fortemente substantivo e de pratica jurisprudencial recém enunciada, mas também oferecem contribuições para explicar os fenômenos jurídicos, inclusive criá-los.

As vozes críticas ao neoconstitucionalismo, como indica Carbonell, afirmam que nenhum desses três elementos é, em rigor, novidade, pois já estavam bem analisados pelas coordenadas teóricas tradicionais do positivismo da primeira metade do século XX. No entanto, como também sustenta o constitucionalista mexicano, a novidade está no conjunto: na reunião dos três elementos, compartilhando coordenadas de tempo e espaço muito parecidas.

Nota-se, também, que encontramos na tradição recente textos constitucionais substantivos e, outrossim, o ativismo judicial já está em questão desde a Segunda Guerra Mundial. No entanto, o que se percebe nos primeiros anos do século XXI é o conjunto dos três elementos supra destacados, e mais que isso, a novidade em seus efeitos, vale dizer, a observação do Estado constitucional de direito em funcionamento.

Como postulados centrais do neoconstitucinalismo temos: 1) caráter específico diferente da perspectiva civilista, baseada na subsunção - da interpretação das normas constitucionais; 2) uso do direito comparado pelos juizes das Cortes Superiores; 3) lugar central dos direitos fundamentais e sua projeção nas relações entre particulares ${ }^{92}$; 4) a preocupação com a efetivação dos direitos sociais; 5) o papel do Estado na defesa dos direitos como a liberdade de expressão etc.

Destaca por fim o constitucionalista mexicano, a convicção democrática que anima a todos aqueles que advogam o neoconstitucionalismo - o que fica mais bem explicado à luz das considerações deste arrazoado que articulam o neoconstitucionalismo com o patriotismo constitucional $^{93}$. Afinal todos aqueles que trabalham nesse paradigma in fieri estão cientes de suas ambiguidades, como por exemplo, o perigo de um incremento irrazoável do poder dos juizes e uma certa limitação da atividade do legislador.

\footnotetext{
${ }^{92}$ Cresce entre a melhor doutrina constitucionalista brasileira a incorporação do debate oriundo da experiência constitucional alemã acerca da eficácia direta dos direitos fundamentais (Drittwirkung) nas relações privadas. Uma via expansiva dos direitos fundamentais se dá através do fenômeno da sua irradiação horizontal, vale dizer, os direitos fundamentais deixam de ter apenas efeitos verticais sobre o Estado e os órgãos da administração pública e passam a ter efeitos horizontais em face das entidades privadas, exercendo influência nas relações jurídicas entre particulares. É o fenômeno caracterizado pela doutrina tedesca como Drittwirkung der Grundrechte. Como leciona José Gomes Canotilho: “a idéia de Drittwirkung ou de eficácia directa dos direitos fundamentais na ordem jurídica privada continua, de certo modo, o projecto da modernidade: modelar a sociedade civil segundo os valores da razão, justiça, progresso do Iluminismo." In: CANOTILHO, José Joaquim Gomes. "Civilização do direito constitucional ou constitucionalização do direito civil? - A eficácia dos direitos fundamentais na ordem jurídico-civil no contexto do direito pós-moderno". In: GRAU, Eros Roberto e GUERRA FILHO, Willis Santiago (org.). Direito constitucional, op. cit., p.114. Deve-se salientar que, neste mesmo texto, o professor de Coimbra, servindo-se de uma ótica inspirada na teoria dos sistemas autopoiéticos, também questiona a capacidade de efetivação dos potenciais emancipatórios presentes nas ordens jurídicas contemporâneas em face da crescente autonomia dos sub-sistemas econômico e político. Quanto ao posicionamento de Canotilho, expendi algumas considerações no texto "O direito entre o moderno e o pós-moderno: é possível escapar da antinomia Habermas/Luhmann?” p. 15 até 26. In: DINIZ, Antonio Carlos de Almeida. Teoria da degitimidade do direito e do Estado: uma abordagem moderna e pós-moderna. São Paulo, Landy Editora, 2006. Para uma explicação mais ampla sobre a Drittwirkung der Grundreche, permitome mais uma vez remeter ao meu livro Jürgen Habermas: filósofo do direito, op. cit. p. 18 e 19.

${ }^{93}$ Sobre a problemática do patriotismo constitucional, no âmbito da discussão acerca da motivação política nas complexas sociedades democráticas do capitalismo tardio, no texto "Patriotismo constitucional e patriotismo republicano". In: DIREITO, Carlos Alberto Menezes; TRINDADE, Antonio Augusto Cançado; PEREIRA, Antonio Celso Alves. (Org.). Novas perspectivas do direito internacional contemporâneo. Estudos em homenagem ao professor Celso de D. Albuquerque Mello. Rio de Janeiro, Renovar, 2008.
} 


\title{
Adendo: O Cânone Neoconstitucional
}

\begin{abstract}
(...) não basta a entrada em vigor positivista das normas para assegurar duradouramente sua validez social. A imposição duradoura de uma norma depende também da possibilidade de mobilizar, num dado contexto da tradição, razões que sejam suficientes pelo menos para fazer parecer legítima a pretensão de validez no círculo das pessoas a que se endereça. Aplicado às sociedades modernas, isso significa: sem legitimidade, não há lealdade das massas."

Grifos do autor
\end{abstract}

Jürgen Habermas

Embora Habermas não seja um autor neoconstitucionalista - como já explicado certamente foi o seu trabalho consolidando a abordagem pós-positivista que, finalmente, ofereceu uma opção plausível à superação do positivismo jurídico. Se no início dos anos 90, Habermas - tanto no plano filosófico como jurídico - ofereceu uma compreensão geral da história, estruturação e funcionamento do direito contemporâneo que recolocou tanto o problema das relações entre direito, moral e política, quanto a questão da legitimidade política num outro patamar da história do direito ocidental em indiscutível cenário para além do positivismo jurídico. Nas duas décadas que se passaram desde a publicação do tratado Facticidade e validade a crítica ao positivismo jurídico só fez crescer no campo do pensamento jusfilosófico e constitucional. Como já destacado, as diversas nomenclaturas assumidas pelas variantes do positivismo jurídico - inclusivo, exclusivo, crítico (como em Ferrajoli) etc. - demonstram que esta corrente está na defensiva em relação aos ataques dos autores pós-positivistas e/ou neoconstitucionalistas ao paradigma jurídico hegemônico na última centúria. O crescente, e quase inacompanhável, número de referências, artigos e também livros na literatura europeia e latino-americana acerca do neoconstitucionalismo permite que se afirme a centralidade deste debate para os estudos jusfilosóficos e constitucionalistas contemporâneos. A constatação de Alfonso García Figueroa, em 2007, de que o neoconstitucionalismo era um paradigma jurídico in fieri, já se encontra, hoje em 2012, recontextualizada no sentido da quase consolidada presença de um novo quadro de referência teórico à disposição dos estudiosos do direito nos Estados Constitucionais do capitalismo avançado.

A publicação de dois livros, um em 2009 no Brasil, Neoconstitucionalismo ${ }^{94}$, e, em 2010, na Espanha, El cânon neoconstitucional ${ }^{95}$, impõe uma constatação: a centralidade desse debate para todos aqueles que se preocupam com os destinos dos ordenamentos jurídicos contemporâneos.

Em relação a estes dois extensos livros (circa de 900 páginas no primeiro e 500 no segundo), não terei tempo agora de enfrentar os inúmeros temas neles apresentados. Quanto ao livro Neoconstitucionalismo (Forense, 2009), foi possível ali reunir trabalhos de amigos e colegas - do Rio, e de várias partes do nosso país, e também de colegas espanhóis protagonistas da metodologia neoconstitucionalista, como: Luís Prieto Sanchís e Alfonso García Figueroa. Este livro, de largas dimensões, demonstra o amadurecimento do debate

\footnotetext{
${ }^{94}$ QUARESMA, Regina; OLIVEIRA, Maria Lúcia de Paula; OLIVEIRA, Farlei Martins Riccio de. (coords). Neoconstitucionalismo. Rio de Janeiro, Forense, 2009.

95 CARBONELL, Miguel; JARAMILLO, Leonardo García. El canon neoconstitucional. Madrid, Editorial Trotta, S.A., 2010.
} 
jurídico nacional: por um lado, incorpora através de processos por vezes sofisticados de filtragem teórica, o debate em torno do neoconstitucionalismo - originalmente encampando os autores hispano-falantes e italianos - às questões atinentes ao debate nacional; por outro, são explorados os desdobramentos do paradigma neoconstitucionalista em diversos ramos do direito positivo. Com seu peculiar estilo, no prefácio dessa obra, afirma o jusfilósofo português Paulo Ferreira da Cunha:

\begin{abstract}
Portanto, a primeira função do neoconstitucionalismo é a de fazer reviver, na sua original pureza, o que já estava no próprio consticionalismo moderno, mas fora olvidado, desprezado, obinubilado, e até sufocado na voragem dos últimos dois séculos. Aliás, tudo o que é "neo-", "pós-", "ultra-" e até "ante-" participa profundamente do radical de que se afirma desinência de algum modo recuperadora ou superadora. Contudo, o neoconstitucionalismo, não se limita a uma revivescência com mais ou menos variantes; antes, procura ser, por vezes, na sua pluralidade de caminhos, uma nova procura para um novo paradigma jurídico. Na verdade, a contemporaneidade jurídica já vive, na prática, uma nova esperança, a dos direitos humanos, sem que o Direito em geral se tenha adaptado, na sua filosofia de base e na sua teoria geral, a essa nova forma de encarar o mundo pelos olhos da juridicidade. Imerso que está em velhos psitassismos de manual, em grande medida cunhados na teoria geral da relação jurídica do direito subjetivo individualista e suas emanações. "96
\end{abstract}

Há três ideias-força nesta passagem que gostaria de sublinhar. A primeira, a relação entre o prefixo neo e a retomada daquilo que ele qualifica, ou seja, o constitucionalismo moderno. $\mathrm{O}$ neoconstitucionalismo assume claramente ares iluministas. Não adota nenhum discurso irracionalista acerca da vida do direito na contemporaneidade, nem endossa qualquer posição próxima ao palavrório pós-moderno de fim de cultura, fragmentação das narrativas, incomensurabilidade de discursos etc. A segunda, a de que nas sociedades complexas do capitalismo tardio a vida social passa a ser permeada pelas normas jurídicas ("encarar o mundo pelos olhos da juridicidade"). Terceiro, o neoconstitucionalista abandona o privilégio do ponto de vista privatista à compreensão do ordenamento jurídico; o centro de sua vida agora é o direito constitucional.

$\mathrm{Na}$ também monumental obra organizada pelos juristas Miguel Carbonell e o colombiano Leonardo García Jaramillo, tem-se uma novidade em relação à série de livros acerca do neoconstitucionalismo, organizados por Carbonell. Neste último volume é incluído pela primeira vez o trabalho de importantes constitucionalistas americanos (Jack M. Balkin e Sanford Levinson) ao lado do debate entre as comunidades hispano e italiano falantes constituidoras dos dois primeiros volumes e parte significativa deste terceiro. Na orelha desta obra, apresenta-se uma síntese das características e do peso representado pelo neoconstitucionalismo no debate jurídico contemporâneo em determinados países da tradição romano-germânica:

O neoconstitucionalismo não só se converteu na corrente mais moderna e que melhor explica os desenvolvimentos recentes do constitucionalismo, senão a que forneceu o enquadramento à consolidação e expansão da democracia constitucional, reforçou a vigência do argumento dos princípios do direito, sustenta o valor normativo da Constituição, o efeito de irradiação dos diretos fundamentais no ordenamento jurídico e sua eficácia horizontal, assim como a dimensão ideal e crítica do direito; igualmente incidindo na configuração e concepção contemporânea dos direitos fundamentais e de sua aplicação. Tudo isso faz com que o neoconstitucionalismo seja a teoria jurídica com maior expansão no campo do

\footnotetext{
96 FERREIRA DA CUNHA, Paulo. "Prefácio", In: QUARESMA, Regina, et al (coord.)

Neoconstitucionalismo. Rio de Janeiro, Forense, 2009.
} 
pensamento jurídico contemporâneo e a que está tendo maior influência na prática, no âmbito europeu e latinoamericano. Esse livro dá conta da compreensão canônica do neoconstitucionalismo através de seus mais relevantes expoentes. ${ }^{97}$

A referência, mesmo que breve, a estas duas últimas obras serve para, por um lado, constatar a presença incontestável do movimento neoconstitucionalista no panorama contemporâneo de ideias; e, por outro, destacar para o leitor brasileiro um vasto material disponível às pesquisas futuras.

IV. A motivação das decisões judiciais: C.F. art. 93-IX -O princípio neoconstitucionalista.

Merece também que fique aqui consignado o alerta: o principal "obstáculo" posto no horizonte dessa nova configuração teórica e de sua implementação em nossa cultura jurídica reside no alargamento dos poderes dos juízes. Como este alargamento da discricionariedade judicial não se transformará em arbítrio? De que forma entender a tradicional estrutura da divisão dos poderes tendo agora como referência, dentro do paradigma neoconstitucionalista, Cortes Constitucionais que funcionam de fato como legisladores intersticiais? Estaremos condenados ao subjetivismo ou ao decisionismo judicial? Serão, como sugere Calsamiglia, os tribunais constitucionais os déspotas esclarecidos do século XXI?

No que tange a este problema, Prieto Sanchís, em recente entrevista respondendo à indagação de Pedro Grández Castro acerca da estrutura do direito em "tempos de constitucionalismo" (as aspas estão na questão formulada ao jurista espanhol, e eu acrescentaria tempos de neoconstitucionalismo), nos quais se observa uma necessidade real de que os magistrados exercitem um espaço de discricionariedade e onde os controles são peças fundamentais à legitimação dessa atuação, afirma:

Pelo que se refere à discricionariedade, esta me parece inquestionável; no entanto ela deve ser referenciada ao marco do constitucionalismo e do conseguinte juízo de ponderação. Sem embargo, a tentação em pensar em controles externos - ou seja, políticos - deve ser rigorosamente excluída. Não cabe pensar em outros controles que não sejam os próprios do sistema judicial de recursos. E isso sim, em uma crescente e mais rigorosa cultura da motivação: as leis se legitimam pela autoridade da qual procedem; as sentenças só por suas boas razões (grifo meu) ${ }^{98}$

Imparcialidade, boa-fé, honestidade, responsabilidade social e capacidade teórica impõem-se aos magistrados. Como afirma Alexy "os juízes não são anjos nem heróis", contudo, a ampliação da latitude discricional da atividade judicante e, ipso facto, da responsabilidade dos magistrados, exige uma mais cuidadosa motivação das decisões judiciais respaldada nos parâmetros argumentativos referenciados às teorias da argumentação. Quanto à competência teórica, usando uma imagem trivial, nossos juízes, sobretudo os mais novos, terão que "desempenhar" como as crianças de classe média das

97 CARBONELL, Miguel; JARAMILlO, Leonardo García. "Prólogo: desafíos y retos del canon neoconstitucional” In: El canon neoconstitucional. Madrid, Editorial Trotta, S.A., 2010.

${ }^{98}$ SANCHÍS, Luis Prieto. Jueces y justicia en tiempos de constitucionalismo - entrevista al Profesor, Luis Prieto Sanchís. Op. cit., p. 3. 
novas gerações, obrigadas agora a aprender mais de uma língua estrangeira para enfrentar o competitivo mercado de trabalho. Assim, além do já exaustivo conhecimento de dogmática jurídica, terão que aprofundar seus conhecimentos extra-dogmáticos, como em filosofia do direito - hermenêutica e argumentação jurídica, sobretudo -, políticas públicas e noções de economia. Quanto às questões relativas às virtudes morais, a resposta é mais difícil. Acredito na seriedade, honestidade e no compromisso do Judiciário brasileiro. Não preciso me valer do recurso retórico: "há juízes em Berlim!"; contudo, não posso deixar de conclamar à responsabilidade ética dos nossos decisores judiciais e esperar que o fortalecimento de mecanismos fiscalizadores da atuação do Judicário - não só por meio de alguma forma de controle externo ${ }^{99}$, mas sobretudo pela ampliação e pelo fortalecimento de um espaço público jurídico, norteado por uma cultura da discussão argumentativa - possa garantir que a ordem jurídica e sua aplicação contribuam para o desenvolvimento da democracia em nosso país. (Quanto a um modelo ponderado de "controle" do Judiciário - diferentemente do afirmado por Luís Prieto Sanchís, já que o nosso Conselho Superior de Justiça não tem competência sobre o mérito das decisões judiciais - a nossa estrutura institucional contém mecanismos capazes de garantir um equilíbrio político/democrático. A atuação deste último se apresenta como um instrumento importante de fiscalização do Judiciário. Com efeito, em estreita consonância com a arquitetônica constitucional de nosso país, podemos pensar numa certa estrutura de "freios e contrapesos" na relação entre o Supremo Tribunal Federal e o Conselho Federal de Justiça, de acordo com a concepção apresentada por Luís Roberto Barroso quando afirma: “ (...) a relação do Judiciário com a sociedade deve passar por um órgão de controle externo, na verdade misto, apto a promover a comunicação adequada entre as duas instâncias. Uma via de mão dupla, capaz de transmitir as expectativas dos cidadãos e de compreender as circunstâncias das instituições judiciais. Dentre outras funções, ao Conselho Nacional de Justiça caberia, sem interferir na atividade jurisdicional, planejar estrategicamente a instituição, reivindicar verbas e compromissos, apresentar relatórios estatísticos, zelar pela universalização do acesso à

Justiça e, quando for o caso, punir desvios de conduta.”)

A questão crucial situa-se no desenvolvimento de uma cultura argumentativa, vale dizer, a comunidade jurídica deve se empenhar para salientar a relevância de um cuidadoso respeito ao ditame consagrado no artigo 93, inciso IX de nossa Constituição. A motivação das decisões judiciais ${ }^{130}$, em especial em sede constitucional, torna-se um assunto central dos debates justeoréticos. E me permitindo uma certa liberdade diria que os filósofos do direito devem (à semelhança do papel atribuído por Habermas aos filósofos, isto é, os guardiões da racionalidade) assumir a função de guardiões do artigo 93, inciso IX. Certamente, em relação a essa problemática, o diálogo entre constitucionalistas e jusfilósofos deve se estreitar cada vez mais. E devemos logo convocar os processualistas ${ }^{100}$ para participar dessa discussão fundamental para o futuro da legitimidade da atuação do Judiciário em nosso país.

\footnotetext{
${ }^{99}$ BARROSO, Luís Roberto. "O controle externo é favorável ao Judicário”. In: Opinião. Folha de São Paulo, 15 de fevereiro de 2004, p. 3. 130 Na literatura pátria recente confiram-se os seguintes artigos no livro Processo e Constituição - estudos de homenagem ao professor Barbosa Moreira, São Paulo, Revista dos Tribunais, 2006: GUERRA, Marcelo Lima. "Notas sobre o dever constitucional de fundamentar as decisões judiciais" e DIAS, Ronaldo Brêtas de Carvalho. "A fundamentação das decisões jurisdicionais no Estado Democrático de Direito". ${ }^{100}$ Quem já acompanha a discussão no âmbito da processualística brasileira é Luis Guilherme Marinoni, como por exemplo em seu livro Curso de processo civil, volume I: teoria geral do processo, São Paulo, Editora Revista dos Tribunais, 2006, pág. 40 a 45. A articulação do neoconstitucionalismo com o processo civil é feita por CAMBI, Eduardo. "Neoconstitucionalismo e neoprocessualismo". In: Revista do programa de fundamentais,
} 
Em relação a essa problemática supradestacada, peço licença para remeter o leitor ao texto "Posfácio: notas sobre motivação das decisões judiciais"132 (De onde retirei alguns dos parágrafos incluídos neste item). Neste trabalho, procuro não só realizar uma reflexão a respeito da temática da motivação das decisões judiciais mas também articulá-la com as questões mais amplas de filosofia jurídica atinentes ao pós-positivismo e ao neoconstitucionalismo. Naquela ocasião, utilizei como um dos elementos teóricos centrais de minha reflexão, o magistério de Michele Taruffo. Em trabalho recente, o insigne processualista chama a atenção especificamente da importância da inclusão da obrigatoriedade da motivação das decisões judiciais nos textos constitucionais hodiernos (Itália, Espanha e Portugal). Assim, motivar uma decisão passa a ter tanto um valor político fundamental quanto um valor político instrumental. Arrolo aqui uma longa citação do jurista italiano que circunscreve com maestria esta nova ancoragem constitucional desta tradicional problemática processualista, destacando o valor político fundamental e o instrumental desta constitucionalização de um princípio processual:

Devido a este gênero de razões cheguei a formular uma distinção entre a função endoprocessual da motivação, vinculada ao problema da impugnação no sentido apenas

políticas públicas e protagonismo judiciário. São Paulo, Editora Revista dos Tribunais, 2009, respondeu a esta conclamação. (Obviamente não estou afirmando que este livro surgiu do meu repto, mas sim de uma convergência geracional de preocupações teorético-políticas. Na próxima apresentação desta pesquisa tratarei com mais vagar deste importante livro). 132

MAIA, Antonio Cavalcanti "Posfácio: Notas sobre motivação das decisões judiciais" In: GRANZINOLI, Cássio Murilo Monteiro. Interpretação e argumentação jurídica: uma contribuição para a fundamentação e justificação das decisões judiciais. Rio de Janeiro, Forense, 2009. Em relação à temática da motivação, confirase o texto: FIGUEROA, Alfonso García. "A motivação. Conceitos fundamentais". In: MOREIRA, Eduardo Ribeiro (org.). Argumentação e o Estado Constitucional. São Paulo, Ícone, 2012. Mais uma vez as investigações de Alfonso García Figueroa auxiliam a qualificação do debate justeorético em nosso país. Neste artigo em particular, articula as teorias-padrão da argumentação jurídica (na expressão já consagrada de Atienza) de Alexy e MacCormick com as questões da processualística relativas à motivação - ou justificação, como sustenta Alfonso para afastar a dimensão psicológica e acentuar a argumentativa - deste crucial momento da aplicação do direito. 133

TARUFFO, Michele. "Prólogo a la edición española". In: La motivación de la sentencia civil. Madrid, Editorial Trotta/Tribunal Electoral del Poder Judicial de la Federación, 2011, p. 19. Quanto à relação das pesquisas de Michele Taruffo com os jusfilósofos capitaneadores do movimento pós-positivistas (e, em muitos casos, neoconstitucionalistas) confira-se também a seguinte passagem, em texto onde realiza um balanço do pensamento jurídico contemporâneo vis-à-vis aos mais de trinta anos passados, deste a publicação em 1975, deste livro, já um clássico da literatura jurídica Novecentista "Devo, ademais, destacar o que muitos dos livros mais importantes relativos ao raciocínio do juiz ainda não haviam sido publicados. Era bastante conhecido pósgraduação em Direito da Universidade Federal da Bahia. Salvador, Fundação Faculdade de Direito da Bahia Editora, 2008. A primeira vez que utilizei este argumento (e a convocação dos processualistas ao debate) foi em 2006, no texto "As transformações dos sistemas jurídicos contemporâneos: apontamentos acerca do neoconstitucionalismo". In: Crítica - Revista de filosofia n ${ }^{\circ} 34$, volume 11. Londrina, Universidade Estadual de Londrina, 2006. Eduardo Cambi, em seu trabalho Neoconstitucionalismo e neoprocessualismo: direitos entre os filósofos do direito, mas não particularmente entre os juristas, o livro de Hart, mas este era substancialmente o único volume que se ocupava do raciocínio jurídico em uma perspectiva analítica. Faltava ainda, para então, a aparição de vários textos que se tornaram sucessivamente pontos de referência essenciais para quem quisera ocupar-se a nível de teoria geral dos problemas relativos ao raciocínio jurídico, e do raciocínio do juiz em particular. Bastam poucos exemplos para ilustrar essa afirmação: o volume de Neil MacCormick sobre o raciocínio jurídico é de 1978, o de Aleksander Peczenik sobre a justificação jurídica é de 1983, o de Aulis Aarnio - também sobre a justificação jurídica - é de 1987. Ademais, o livro fundamental de Robert Alexy sobre a argumentação jurídica foi publicado em 1978. Também em 1978, finalmente, é o volume de Ronald Dworkin sobre os "direitos levados a sério". Como se pode ver destas referências sintéticas, é essencialmente entre a segunda metade dos anos setenta e a primeira metade dos anos oitenta quando floresce uma ampla literatura que aborda os temas da racionalidade do raciocínio jurídico e da argumentação justificativa. Frequentemente estes temas são analisados em uma perspectiva muito geral. 
assinalado, e a função extraprocessual da motivação, que se compreende somente no contexto das garantias fundamentais da administração de justiça que são típicas do Estado democrático moderno. Esta segunda função está estreitamente relacionada com a concepção democrática do exercício do poder, segundo a qual quem exerce um poder deve justificar as modalidades pelas quais este é exercido de um modo determinado e não de outro. Neste sentido, a obrigação de motivar garantida constitucionalmente assume um valor político fundamental: é o instrumento por meio do qual a sociedade está em disposição de conhecer e de verificar as razões pelas quais o poder jurisdicional é exercido de determinados modos nos casos concretos. Se trata de um valor político em si, posto que a possibilidade de controlar o exercício do poder coloca a base da soberania na sociedade, que está em condições de poder exercer seu controle. Se trata também de um valor político instrumental, devido a que através do controle sobre a motivação, é possível verificar se se cumpriu com outros princípios fundamentais, como os da legalidade e da imparcialidade da administração da justiça, que são típicos do moderno Estado de direito. ${ }^{133}$

A motivação das decisões judiciais é tradicionalmente uma garantia endoprocessual. Princípio de garantia do jurisdicionado e de exigência de transparência das decisões judiciais - opondo-se ao segredo característico do Absolutismo, consolidou-se a partir da Revolução Francesa como elemento cardeal da estrutura do Estado liberal. Princípio geral que contribuiu para a racionalidade do sistema de administração da justiça, garantia de respeito às liberdades públicas vincula-se ao princípio do livre convencimento do juiz e a independência da magistratura. No Código de Processo Civil Brasileiro está expresso no artigo 458. Questão das mais tormentosas no âmbito da processualística, tornou-se elemento central do debate constitucional contemporâneo. Ora, o constitucionalismo do pós-guerra elevou essa garantia do âmbito processual à sede constitucional, v.g. artigo 93, inciso IX da Constituição Federal. Elenco a seguir algumas cogitações acerca desta problemática no âmbito do processo em estreita articulação com a temática mais ampla da argumentação jurídica.

Saliente-se que correlata à centralidade assumida pelo approach argumentativo nos debates metodológicos nos últimos 20 anos (cf. sobre esta "virada metodológica" As razões do direito - teorias da argumentação jurídica de Manuel Atienza; e também o meu texto: "Posfácio: a importância da dimensão argumentativa à compreensão da práxis jurídica contemporânea". In: CAMARGO, Margarida Maria Lacombe. Hermenêutica e argumentação: uma contribuição ao estudo do direito. Rio de Janeiro, Renovar, 2001), tem-se como foco principal o âmbito do raciocínio judicial posto em movimento nas decisões das Cortes Superiores - onde cada vez mais o Judiciário torna-se um legislador intersticial -, em especial, as Cortes Constitucionais.

No âmbito da metodologia contemporânea, não é nem a argumentação elaborada pelo advogado, nem aquela estruturada pelo juiz monocrático, o foco de atenções da abordagem argumentativa: o seu alvo de exame são os raciocínios presentes nos arestos dos tribunais superiores, já que são eles os fixadores dos grandes lineamentos norteadores da jurisprudência, elemento fundamental do funcionamento do direito.

Examinar o modo pelo qual os tribunais superiores chegam ao termo das lides que lhes são submetidas à apreciação, e até que ponto tais decisões seguem os preceitos lógicos formais e também os parâmetros argumentativos necessários ao alcance de uma decisão intersubjetivamente justificada, revela-se como uma das tarefas mais significativas do trabalho doutrinário e de pesquisa. Destaca-se que uma das grandes novidades 
metodológicas sobre a motivação das decisões judiciais hodiernamente está no fato de não cingi-la à verificação dos indispensáveis cânones da lógica formal - com seu mecanismo

básico do silogismo, ideias de não contradição - mas estar preocupado com as delicadas operações hermenêutica-argumentativas postas em movimento pela necessidade de ponderação dos princípios constitucionais. Neste sentido, afirma Michele Taruffo, "non è quindi necessario, e non è possibile, che la motivazione risponda ai canoni della lógica formale; è invece sufficiente, ed è comunque necessario, che derivano dalle analisi del ragionamento giuridico (v. ad es. gli studi di Wroblewski, Aarnio. Alexy, Peczenik)"101

Assim, com a enorme relevância obtida pelo Judiciário a partir da CF 88 e, por conta disso, da maior responsabilidade em convencer o "auditório tendencialmente universal" de que suas decisões são racionais, apreensíveis, fundamentadas (razões, motivos...), coerentes. De fato, o direito não está apenas preocupado com a única "resposta correta" (estas só poderiam ser obtidas na situação contrafática do Juiz Hercules, de Dworkin), mas sim com respostas fundamentadas, plausíveis, racionalmente justificadas. No tocante à importância da motivação das decisões, Perelman arrola uma passagem, apontando os diversos aspectos nos quais este procedimento encontra relevância:

Motivar una decisión es expresar sus razones y por eso es obligar al que la toma, a tenerlas. Es alejar todo arbitrio. Unicamente en virtud de los motivos el que ha perdido un pleito sabe como y por qué. Los motivos le invitan a comprender la sentencia y le piden que no se abandone durante demasiado tiempo al amargo placer de 'maldecir a los jueces'. Los motivos le ayudan a decir si debe o no apelar o, en su caso, ir a la casación. Igualmente le permitirán no colocarse de nuevo en una situación que haga nacer un segundo proceso. Y por encima de los litigantes, los motivos se dirigen a todos. Hacen comprender el sentido y los límites de las leyes nuevas y la manera de combinarlas con las antiguas. Dan a los comentaristas, especialmente a los comentaristas de sentencias, la possibilidad de compararlas entre sí, analizarlas, agruparlas, clasificarlas, sacar de ellas las oportunas lecciones y a menudo también preparar las soluciones del porvenir. Sin los motivos no podríamos tener las 'Notas de jurisprudencia' y esta publicación no sería lo que es. La necesidad de los motivos entra tanto dentro de nuestras costumbres que con frecuencia traspasa los límites del campo jurisdiccional y se va imponiendo poco a poco en las decisiones simplesmente administrativas cada vez más numerosas. ${ }^{102}$

Nesse quadro atual, onde os magistrados dispõem de uma área de liberdade maior do que a tradicionalmente garantida em nossa história jurídica, impõe-se uma atenção mais cuidadosa à questão concernente às justificativas pelas quais os juízes chegam às decisões que dirimem as lides a eles submetidas. A situação demanda cuidado, posto, mesmo antes da atual conjuntura teórica balizada pelo pós-

positivismo/neoconstitucionalismo, já podiam ser notadas as insuficiências relativas à fundamentação das decisões, como leciona J. C. Barbosa Moreira:

Comme le lecteur ne manquera pas d'apercevoir, la situation au Brésil nous paraît, somme toute, peu satisfaisante. La motivation des décisions de justice en général, sans exclusion des arrêts d'appel, laisse souvent à désirer, et des défauts relatifs au

\footnotetext{
${ }^{101}$ TARUFFO, Michele. "Il significato costituzionale dell'obligo di motivazione". In: GRINOVER, Ada Pelegrini, DINAMARCO, Cândido Rangel e WATANABE, Kazuo (coords.). Participação e processo. São Paulo, Editora Revista dos Tribunais, 1988, p.47.

${ }^{102}$ SAUVEL, T. "Histoire du jujement motivé", Revue du droit publique, 1955, pgs. 5-6. Apud PERELMAN, Chaïm., La lógica jurídica y la nueva retorica. Madrid, Civitas, 1979, pp. 202 e 203.
} 
raisonnement y sont presque toujours pour beaucoup, même si l'on passe sous silence les vices logiques élémentaires qui se glissent parfois dans les jugements. ${ }^{103}$

É claro que essa problemática não é exclusiva da cultura jurídica brasileira. Toda essa discussão metodológica mencionada neste trabalho, se encontra no cerne de um acalorado debate na Europa acerca do problema da fundamentação e da estruturação das decisões judiciais, correlato, ao já mencionado, alargamento da área de discricionariedade dos juízes observado em diversos países europeus nos últimos anos. Desta forma, assiste-se a uma demanda - proveniente em especial doutrina, que no quadro teórico do póspositivismo/neoconstitucionalismo, ganha um protagonismo ímpar na história jurídica ocidental - de um maior cuidado e rigor argumentativo nas decisões judiciais. Essa tendência acompanha um fenômeno de uma progressiva influência mútua dos dois modelos de atuação judicial existentes na tradição ocidental: o juiz continental, adstrito no seu agir predominantemente aos textos legais, e o juiz da common law, cingido sobretudo pelo precedente judicial. Ora, o que observamos é um crescente alargamento da área de atuação do juiz continental, sendo assim um recurso metodológico indispensável à compreensão desse maior protagonismo consiste na melhor compreensão e esforço de integração de aspectos do sistema jurídico da common law (em especial o americano e, sobretudo uma experiência ainda pouco conhecida dos juristas brasileiros, a canadense; quanto à experiência inglesa, a distância é de tal extensão - afinal, inexiste Constituição nesse sistema - que dificulta uma comparação profícua).

Assim, devemos pensar em que medida a sociedade, os profissionais do direito, e os teóricos - acredito terem os teóricos neste particular, por conta da sua relativa independência, importante papel nesta questão - podem suscitar um debate no sentido de exigir que as motivações dos juízes, em suas sentenças, sejam mais explícitas, mais detalhadas e conforme os cânones da boa argumentação, seguindo as regras lógicas e padrões argumentativos pertinentes, bem como atentas a uma justificação mais ampla atenta às dimensões morais e políticas - necessárias ao deslinde dos casos difíceis. Este reconhecimento de que no Estado democrático de direito a motivação das decisões constitui um dos principais deveres dos juízes abre a possibilidade para que haja uma cobrança e uma fiscalização por parte dos cidadãos em face ao Judiciário.

Com efeito, um trabalho importante dos profissionais ligados à vida acadêmica é o de enfatizar a necessidade de uma mais cuidadosa fundamentação nas decisões judiciais, talvez porque pode-se reconhecer uma dificuldade por parte dos advogados de cobrarem

${ }^{103}$ MOREIRA, José Carlos Barbosa. "Raisonnements Judiciaires dans les Cours d'appel”. In: Temas de direito processual, Rio de Janeiro, Editora Saraiva, 1994, p. 128. Há outros trechos do mesmo texto esclarecedores desta passagem: "Le thème des raisonnements des cours d'appel suscite une problématique très étendue et multiforme. On essaierait en vain d'en épuiser l'étude dans le cadre d'un rapport du genre de celui-ci. Nous avons jugé opportun de fournir quelques donnés sur le panorama qu'offre à ce point de vue le droit brésilien, tel qu'il se révèle non seulement par les textes législatifs, mais aussi et surtout par la pratique judiciaire. D'où les remarques critiques que nous avons été portés à faire au long de notre exposé.(...) L'imperfection fondamentale réside sans doute dans l'insuffisante explicitacion du raisonnement. En ce qui concerne la motivation in facto, les points cruciaux sont l'appréciation des preuves, la réparticion (éventuellement, l'atténuation, voire l'inversion) de l'onus probandi, l'invocation de faits dits notoires (ou tacitement admis comme tels) et de "règles d'experience": dans tous ces domaines, un effort plus vif de justification serait extrêmement souhaitable. Quant à la motivacion in jure, abstraction faite des problèmes courants d'hermeneutique, toujours susceptibles d'entraîner bien des difficultés, ce qui attire principalment l'attention est la question des jugements de valeur: les 
certas posições do Judiciário, o que deixa aos teóricos papel relevante nesta questão. É óbvio que o trabalhador universitário pode ser sempre repreendido por possuir intenções descoladas da prática da vida do direito e por tentar, através das ideias, modificar a realidade - premida pelos imperativos de segurança jurídica e de natureza pragmática - que se impõe

como infensa à interveniência do mundo das reflexões. Certamente esta é uma objeção sempre levantada no horizonte das relações entre teoria e prática. Entretanto, os professores e teóricos têm hoje entre suas tarefas o papel de introduzir estas discussões em nosso meio intelectual.

É claro que ao correlato alargamento do âmbito da discricionariedade dos juízes, em especial daqueles que lidam com o texto constitucional, aumenta a responsabilidade do Judiciário de fundamentar suas decisões, de forma não só a atender e satisfazer aos profissionais do direito (dentro da sua linguagem técnica e, por vezes, quase que cifrada), mas também a abrir esta argumentação a uma comunidade mais larga de cidadãos cultos portadores do direito de ver satisfeito a sua expectativa em reconhecer que a decisão foi a mais equitativa, a mais razoável, a mais plausível no caso concreto. Importa ter em mente uma ideia reguladora: a argumentação utilizada - sobretudo nas decisões que envolvem conflitos de natureza moral, operacionalizadas através da ponderação de princípios, com a correlata aplicação do princípio da proporcionalidade - devem endereçar-se a uma audiência cada vez mais ampla e seguir um telos de uma crescente generalizabilidade de suas decisões. Uma atenção crescente deve ser dada na busca da observância dos critérios intersubjetiváveis de validação.

Esclareço que estou falando num nível de generalização muito ampla. Grande parte do esforço da doutrina contemporânea no âmbito da metodologia do direito dentro da abordagem argumentativa, encontra-se no desiderato do estabelecimento destes critérios racionais e possível operacionalização da pratica jurídica destes critérios. A teoria de Alexy é o exemplo mais insigne deste esforço. Sirvo-me de uma passagem de um texto onde exponho detalhadamente uma série de aspectos teoréticos argumentativos da teoria discursiva do direito e da democracia: "Habermas/Alexy e o discurso prático", (publicado no livro Uma visão interdiscpiplinar. O pensamento vivo de Habermas, organizado por: Alessandro Pinzani, Clóvis Montenegro de Lima e Delamar Volpato Dutra, Florianópolis, Nefiponline, 2009 - acessível on-line no sítio do Departamento de Filosofia da Universidade Federal de Santa Catarina). Assim, afirmei naquela oportunidade: o discurso prático se realiza através de um procedimento argumentativo balizado por uma teoria da argumentação. Com efeito, afirma Alexy, em seu texto "A concepção teorético-discursiva da razão prática", que a teoria do discurso é uma teoria procedimental. A concepção de racionalidade aplicável à teoria do discurso consiste, assim, em uma racionalidade procedimental, universalista. Neste texto seminal são expostas as teses básicas dessa modalidade discursiva - já tendo como pano de fundo as bases do projeto alexyano expostas na sua Teoria da argumentação jurídica - a teoria do discurso racional como teoria da fundamentação jurídica. Com efeito, o discurso prático é racional quando ele cumpre as condições de uma prática argumentativa racional. Estas condições podem ser sintetizadas em um sistema de regras do discurso. Tal sistema, nas palavras de Alexy, constitui, por assim dizer, um "código da razão prática" e funciona alicerçado nos princípios de "consistência, eficiência, testabilidade, coerência, generalizabilidade e sinceridade". O resumo de tal código se encontra nas páginas 283 a 287 da Teoria da argumentação jurídica. Baseado na ideia de que o discurso jurídico é uma forma especial do discurso prático geral, tal proposta se estrutura a partir de uma clivagem básica: 1) as regras e formas do discurso prático geral, divididas em seis itens - as regras 
fundamentais, as regras da razão, as regras de carga da argumentação, as formas de argumentos, as regras de fundamentação e as regras de transição. 2) já as regras e formas do discurso jurídico se subdividem em dois grandes grupos - as regras e formas da justificação interna e as regras e formas de justificação externa. (Esbocei, juntamente com Cláudio Pereira de Souza Neto, breves comentários sobre esse código em "Os princípios de Direito e as Perspectivas de Perelman, Dworkin e Alexy”. In: PeiXinho, Manoel Messias et al (org.). Os princípios da Constituição de 1988, op. cit,. em especial nas páginas 91 a 95).

Assim, esta discussão teórica pode nos municiar de elementos para melhor compreender alguns dos problemas presentes no quadro atual do debate jurídico. Ora, observa-se a existência de uma viva polêmica sobre o papel do Judiciário e do juiz na aplicação da lei, nesta nova configuração político-jurídica que se estruturou no Brasil a partir da Constituição de 88. Eis que a reconstitucionalização implicou nítido alargamento nas funções dos juízes e uma maior participação do Judiciário nos problemas gerais da vida brasileira. Deste modo, cabe à comunidade dos profissionais do direito uma reflexão mais profunda acerca destas questões, tendo em vista que uma abordagem argumentativa oferece novas possibilidades de reflexões no mundo do direito e postula uma integração maior entre a produção doutrinário-acadêmica e o quotidiano do juiz e do advogado.

Ademais, nos últimos anos tem-se frequentemente sustentado uma fiscalização maior da atividade do Judiciário, cogitando-se por vezes o controle externo deste Poder ${ }^{104}$. Trata-se de um debate difícil, complexo e delicado. O Judiciário se apresenta como uma das instituições mais hierarquizadas e burocratizadas da República - e com inerente corporativismo característico de entidades como ele. E quando se aventa qualquer medida no sentido de interferência na sua autonomia há uma reação imediata e quase sempre contrária a qualquer passo em tal direção. Entretanto, pode-se apontar uma outra forma - diferente daquela do controle externo - de procurar garantir mecanismos de fiscalização da sociedade e da comunidade dos operadores do direito em relação ao Judiciário. Tal se daria, basicamente, a partir de uma outra abordagem, situada numa dimensão metodológica, através de um exame mais apurado da fundamentação das decisões, à luz de todas essas cogitações de natureza teórica abertas pela virada argumentativa observada na metodologia jurídica contemporânea.

A par do debate acerca da problemática da motivação das decisões judiciais no campo do processo civil, há um crescente questionamento desta problemática, correlata ao dever constitucional de motivação e ao inegável alargamento da área de influência da atividade judicante na vida político-juridica contemporânea observada nas últimas décadas. Portanto, o debate desloca-se para o âmbito da filosofia jurídica e política, atrelado à própria questão acerca da legitimação da crescente atuação do Judiciário. Como destaca, com sua peculiar capacidade interdisciplinar de compreensão da fenomenologia das recentes transformações constitucionais, Oscar Vilhena Vieira:

É através da racionalização e da argumentação contida na motivação da decisão judicial
que os tribunais assumem o papel de discutir, publicamente, o alcance dos princípios e
direitos que constituem a reserva de justiça do sistema constitucional. Caso consigam
levar a cabo esta tarefa, poderão se transformar num fórum de extraordinária relevância
dentro de um sistema democrático, onde muitas vezes os valores fundamentais ficam
submetidos ao decisionismo majoritário. Com isto não se pretende estabelecer uma

${ }^{104}$ A EC n ${ }^{\circ} 45 / 04$ criou o CNJ - Conselho Nacional de Justiça -, órgão responsável pelo “controle da atuação
administrativa e financeira do Poder Judiciário e do cumprimento dos deveres funcionais dos juízes” (cf. art.
$103-\mathrm{B}, \S 4^{\circ}$, da CF/88).

Revista Quaestio luris, vol.04, no01. ISSN 1516-0351 p.1-86 
hierarquia entre procedimento judicial e procedimento democrático, mas estabelecer ainda que idealmente um procedimento racional para a discussão e aplicação dos princípios de justiça que servem como limites habilitadores do sistema democrático. ${ }^{105}$

Deve-se ainda frisar: a questão relativa à exigência de uma mais cuidadosa fundamentação das decisões judiciais inscreve-se dentro de uma série de temas contemporâneos relativos às reflexões sobre os modelos viáveis de democracia. Certamente este debate se encontra direcionado para os problemas concernentes ao crescente papel que o Judiciário e o direito vêm assumindo na vida dos cidadãos nas modernas democracias de massa. Como corolário destas considerações, tem-se a exigência de uma maior transparência de todas as ações dos funcionários do Estado, o que se dá no campo da atuação dos juízes através de uma mais cuidadosa motivação das suas decisões, sobretudo aquelas concernentes aos princípios constitucionais e direitos fundamentais. Como afirma Perelman, o precursor da abordagem argumentativa do direito, sempre preocupado com a responsabilidade ética do julgador judicial, enquadrando a discussão da motivação no âmbito da democracia contemporânea:

\begin{abstract}
Numa visão democrática do direito, que não considera este como o ato de uma autoridade competente, mas que queria, ademais, que as decisões judiciárias fossem não só legais, mas também aceitáveis, porque não se opõem categoricamente a valores socialmente reconhecidos, o papel do juiz continental cresce singularmente, e se aproxima do papel do juiz anglo-saxão. Mas, ao mesmo tempo, cresce o papel da argumentação e da retórica na aplicação e na evolução do direito. E essa observação diz menos respeito ao advogado do que ao juiz, forçado, cada vez mais, a uma motivação das sentenças que já não se contenta em mostrar a correção formal, mas se esforça em torná-las convincentes. A exposição de motivos será diferente quando couber convencer a opinião pública do caráter razoável da decisão e quando bastar indicar à Corte de Cassação que a sentença não violou a lei. Ao positivismo jurídico sucede, assim, uma visão menos formalista do direito, que insiste na aceitação das decisões judiciárias no meio social ao qual é aplicável o sistema de direito. ${ }^{106}$
\end{abstract}

\title{
Conclusão
}

Estou apenas falando a linguagem do otimismo. São os pessimistas que me chamam de louco. Aliás, o pessimismo é a filosofia dos mortos prematuros, a verdadeira origem filosófica do câncer.

Glauber Rocha

Importa destacar também o seguinte: aqueles que advogam pela hegemonia do paradigma do neoconstitucionalismo preocupam-se com a objeção democrática à criação normativa judicial. Ademais, a demanda de cuidadoso balizamento pelos cânones da argumentação jurídica da aplicação de princípios procura garantir um incremento de racionalidade no deslinde das crescentes controvérsias ensejadas pela interpretação constitucional contemporânea. A inevitabilidade do juízo de ponderação não significa um salto na irracionalidade, pois o respeito a, pelo menos, parte significativa das rigorosas

105 VIEIRA, Oscar Vilhena. “A Constituição como reserva de justiça”. In: Lua Nova, São Paulo, 1997, n 42, p. 91.

${ }^{106}$ PERELMAN, Chaïm. Ética e direito, São Paulo, Martins Fontes, 1996, pp. 557 e 558. 
exigências das teorias da argumentação contemporâneas (como a de Alexy) constitui um procedimento racional que pode no pior dos casos reduzir a arbitrariedade. Ao reconhecer aos juízes uma alargada margem de discricionariedade, os juristas neoconstitucionalistas se engajam com eles num debate que, por um lado, exige um aperfeiçoamento da cultura jurídica brasileira no sentido de uma maior atenção e respeito aos estritos procedimentos de uma argumentação jurídica racional e, por outro, conclama os magistrados à consciência da importância crescente de seu papel nas novas formas de arranjo institucional vigente. Saliente-se mais uma vez o protagonismo também assumido pelo trabalho doutrinário nesta nova quadra da história do pensamento jurídico ocidental. Com efeito, devemos sempre nos lembrar - e os pesquisadores universitários, graças à sua distância das lides e dos interesses forenses, desempenham um papel insubstituível nessa luta - de que a devida motivação judicial é responsabilidade e obrigação dos juízes no Estado democrático de direito.

Last but not least, àquelas vozes céticas que costumam subestimar a importância das reflexões teóricas à práxis concreta das cortes, destaco, e peço desculpas pela extensão da citação, o parecer do ex-magistrado da Corte Constitucional espanhola, Francisco Rubio Llorente acerca da figura cimeira do neoconstitucionalismo nãopositivista:

\begin{abstract}
A teoria dos direitos fundamentais é parte, ainda que parte essencial, de uma construção muito mais ampla, da qual fazem parte, para mencionar apenas alguns grandes títulos, a Teoria da argumentação jurídica e $\mathrm{O}$ conceito e a validade do direito. Esta construção, que situa seu autor entre os grandes nomes do pensamento jurídico contemporâneo, tem, junto a seu vigor teórico, uma enorme importância prática. Os sistemas jurídicos contemporâneos têm todos seu centro nos direitos, como antes tiveram na lei, mas a noção dos direitos não é a mesma em todas as partes. Muito em particular, a noção européia, que Alexy contribuiu poderosamente para explicitar, quando não a edificar, é consideravelmente distinta da norteamericana, ainda que ambas venham da mesma origem e sejam sensivelmente os mesmos os valores protegidos. Daí, a meu juízo, a necessidade de que não só os teóricos, mas também os práticos do direito se familiarizem com esta obra. Tanto para aplicar seus ensinamentos, como para buscar as razões que permitem apartar-se delas, é inescusável conhecê-la. ${ }^{107}$
\end{abstract}

Por fim, após duas décadas de vida de nossa Lei Maior, a consagração de seu epíteto Constituição Cidadã testemunha o papel único desempenhado por este texto político em nossa história política. E ela o é - cidadã -, pois radica o âmago da estrutura política de nossa nação nos direitos fundamentais; e a proposta/aposta do neoconstitucionalismo é operacionalizar o sistema jurídico a partir de uma ideia expansiva dos direitos fundamentais sempre atentos a tormentosa questão da justiciabilidade dos direitos garantidos no artigo $6^{\circ}$ da Constituição Federal. Ora, desde a promulgação de nossa Constituição, aqueles situados à esquerda do espectro político, - marcados pela preocupação com a necessidade do estabelecimento de políticas públicas atentas às necessidades redistributivas - reconheceram o potencial emancipatório de nossa Lei Fundamental. Ficou claro que o desenvolvimento de uma hermenêutica constitucional progressista ${ }^{108}$ impôs-se como uma das principais tarefas

\footnotetext{
${ }^{107}$ LLORENTE, Francisco Rubio. "Presentación”. In: ALEXY, Robert. Epílogo a la teoria de los Derechos fundamentales. Madrid, Fundacion Beneficentia et Peritia Iuris, 2004, p. 11

${ }^{108}$ Quanto a esta corrente na tradição publicista brasileira, sigo o elenco de Cláudio Pereira de Souza Neto na nota 408, nas páginas 260 e 261, de seu livro Teoria constitucional e democracia deliberativa. Um estudo sobre o papel o direito na garantia das condições para a cooperação na deliberação democrática, op. cit.: "Essa trajetória pode ser observada, p. ex., nos estudos de Clèmerson M. Clève. (...) O trabalho que sintetiza, com
} 
teóricas a serem realizadas pelas novas gerações de juristas. Doravante, esta empreitada será realizada à luz do neoconstitucionalismo, norteado pela tese habermasiana de que os cidadãos podem considerar que a Constituição é um projeto coletivo visando à realização cada vez mais completa de um sistema de direitos fundamentais já estabelecidos e atentos para "o sentido profundo do fenômeno total representado pela constitucionalização dos direitos."109

Anexo 1 - Sobre Alfonso García Figueroa

Em relação ao diálogo de Alfonso García Figueroa com o pensamento jurídico brasileiro, trago à colação duas passagens ilustrativas deste crescente intercâmbio. No final prólogo do livro de André Rufino do Vale, A estrutura das normas de direitos fundamentais: repensando a distinção entre regras, princípios e valores, ele realiza um importante enquadramento do novo pensamento jusfilosófico brasileiro: "o leitor encontrará a continuação de um trabalho rigoroso e estimulante (de Rufino, A.C.M) ao que me atrevo a predizer lhe seguirão outros de seu autor e não somente por seu indubitável valor à luz desta investigação, senão também porque este trabalho não se produz no vazio, senão no marco de uma nova filosofia do direito brasileira que está nos oferecendo frutos de grande qualidade. Faz-se algo mais de um mês (pouco depois da triste notícia do falecimento de Miguel Reale) tive a sorte de apresentar uma conferência na Universidade do Estado do Rio de Janeiro (UERJ) e de participar do I Congresso Brasileiro de Argumentação Jurídica e Filosofia do Direito que teve o título "Direito e Razão Prática" e a direção dos professores Thomas Bustamente e Dennis Silva, que se celebrou em Juiz de Fora. Em ambas cidades pude comprovar (...) a renovada energia e a elevação intelectual que a filosofia jurídica tem adquirido hoje no Brasil. Por citar somente alguns exemplos sem nenhum ânimo exaustivo, nos últimos tempos tenho tido a oportunidade de aprender muito dos trabalhos e compilações de Virgílio Afonso da Silva e Antonio Maia, do excelente livro de Humberto Ávila sobre princípios, das reflexões

maior intensidade, essa tendência do direito constitucional brasileiro (...) é a tese de livre docência de Luís Roberto Barroso, publicada sob o título: O direito constitucional e a efetividade de suas normas. Cabe recordar, contudo, que, embora tal movimento se situe predominantemente no contexto da reabertura democrática, algumas de suas bases teóricas já haviam sido assentadas anteriormente. Refiro-me, em especial, aos estudos precursores de J. H. Meirelles Teixeira (Curso de direito constitucional) e de José Afonso da Silva (Aplicabilidade das normas constitucionais), que foram responsáveis pela reformulação da teoria da norma constitucional no Brasil, de modo a se conceder maior normatividade aos dispositivos programáticos. (...) Outros constitucionalistas também deram importantes contribuições a esse movimento de ideias, como é o caso, em especial, de Paulo Bonavides, Eros Roberto Grau, Carmen Lúcia Antunes da Rocha, Carlos Roberto de Siqueira Castro, Celso Antônio Bandeira de Mello, Lenio Streck, Flávia Piovesan, entre outros.” Em relação ao jurista paranaense que encabeça esse insigne elenco supracitado, conferir um dos textos precurssores em nosso pais acerca do neoconstitucionalismo: CLÈVE, Clèverson Merlin. Estado constitucional, neoconstitucionalismo e tributação. MIMEO, sem data. Texto resultante da degravação de conferência proferida no XVIII Congresso Brasileiro de Direito Tributário, promovido pelo Instituto Geraldo Ataliba - IDEPE.

${ }^{109}$ TARUFFO, Michele. "Prólogo a la edición española" In: La motovación de la sentencia civil. Madrid, Editorial Trotta/Tribunal Electoral del Poder Judicial de la Federación, 2011, p. 19. 
alexyanas de Ecio Otto Ramos Duarte; das schauerianas de Noel Struchiner e das discursivas de Marina Velasco, assim como dos trabalhos de Thomas Bustamante ou Claudio Pereira Neto. O texto e o contexto de André Rufino do Vale despertarão no leitor motivos para a reflexão, mas há de ser também uma chamada de atenção sobre o trabalho que se está desenrolando no Brasil". ${ }^{143}$

Em texto mais recente publicado no Peru, novamente integra Alfonso na sua argumentação a doutrina brasileira, iniciando o artigo com referência a autores nacionais (o título da primeira parte "Para uma "filosofia jurídica aplicada" - expressão do constitucionalista carioca Eduardo Ribeiro Moreira). Como ele afirma: "Ontem os códigos; hoje as Constituições. A vingança da Grécia contra Roma" (Citando o texto de Barroso publicado no México em 2008 e em nota de pé de página aduz que tal referência foi previamente reunida por Eros Roberto Grau a partir de uma citação de Paulo Bonavides). Continua Alfonso Figueroa: "Em um livro recente dedicado ao neoconstitucionalismo, o jurista brasileiro Luis Roberto Barroso recorria a estas frases 144

como quem busca condensar em uma só epígrafe o clima espiritual que envolve aos juristas de nossa época. Desde logo, essas palavras podem ser interpretadas de muitas maneiras, mas em todo caso parecem o reflexo de uma boa intuição se identificamos a Roma com a pátria dos juristas e a Grécia com a pátria dos filósofos; a Roma com a pátria do direito e a Grécia com a pátria da virtude. Certamente requereriam alguma cautela se identificamos a Roma com a pátria de um certo casuísmo, mas há em todo caso algo especialmente revelador nessas palavras quando contemplamos a aproximação ao direito que promove o chamado neocontitucionalismo: se a filosófica Grécia não conheceu uma clara decantação dos diversos sistemas normativos, para direito, política, religião e inclusive leis da natureza foram imbricados indivisivelmente em uma única ordem normativa ao que estava submetido o cidadão; em Roma o direito se nos revela mais bem como uma técnica diferenciada e sobressalente ao serviço de todo um Império. Ali nasce propriamente a figura do jurista, do especialista em direito." 110 (Transcrevo agora toda a citação de Barroso utilizada por Figueroa: "A primeira parte da frase 'ontem os códigos, hoje as Constituições' foi pronunciada por Paulo Bonavides, ao receber a medalha Teixeira de Freitas, no Instituto dos Advogados Brasileiros, no ano de 1998. O complemento foi feito por Eros Roberto Grau em discurso publicado separadamente pelo IAB: 'Ontem os códigos, hoje as Constituições. A vingança da Grécia contra Roma, tal como ocorreu, em outro plano, na evolução do direito da propriedade, antes justificado por sua origem, agora legitimado por seus fins: a propriedade que não cumpre sua função social não merece qualquer proteção jurídica"' In: BARROSO, Luis Roberto. El neoconstitucionalismo y la constitucionalización del Derecho, México, UNAMIIJ, 2008).

Em sua crítica à obra do mestre florentino, publicada em 2011,

\footnotetext{
${ }^{110}$ FIGUEROA, Alfonso García "La revancha neoconstitucionalista de Grecia contra Roma: notas sobre la inviabilidad de las reglas en el Estado constitucional” In: Foro jurídico: Revista de Derecho, no 10. Lima, Foro Académico Asociación Civil, abril de 2010.

143 FIGUEROA, Alfonso García. "Prólogo" In: VALE, André Rufino do. Estrutura das normas de direitos fundamentais: repensando a distinção entre regras, princípios e valores, Saraiva, São Paulo, 2009.

144 BARROSO, Luís Roberto. El neoconstitucionalismo y la constitucionalización del Derecho, México, UNAM-IIJ, 2008.
} 
"Neoconstitucionalismo: dos (o tres) perros para un solo collar: Notas a propósito del constitucionalismo juspositivista de Luigi Ferrajoli”, mais uma vez o jusfilósofo espanhol se refere ao debate brasileiro: " $\mathrm{Na}$ área italoiberoamericana o impacto está sendo sentido. Particularmente ilustrativo é o interesse, quando não a adesão, que tem suscitado o neoconstitucionalismo no Brasil. Vid. e. g.: R. QUARESMA et al. (coords.), Neoconstitucionalismo, Rio de Janeiro, Companhia Editora Forense, 2009, e C. PEREIRA

DE Souza Neto e D. SARmento (coords.), A constitucionalização do direito. Fundamentos teóricos e aplicações específicas, Rio de Janeiro, Lumen Juris, 2007. Em tom abertamente crítico, Lenio Luiz STRECK se refere ao fenômeno do "panprincipiologismo em Terrae Brasilis" (citado por FERRAJOLI EM CPCG, nota 9). Entre os diversos autores que tem promovido o neoconstitucionalismo nesse país destaca com luz própria um de seus mais entusiastas defensores: Antonio CAVAlCANTi MAiA (e. g. "As transformações dos sistemas jurídicos contemporâneos: apontamentos acerca do neoconstitucionalismo”, em R. QUARESMA, op. cit., 3-27) cuja formação filosófica habermasiana tem encontrado neste movimento um suporte jusfilosófico idôneo. Veja também: L. BARROSO, El neoconstitucionalismo y la constitucionalización del Derecho, México, UNAM, 2008; E. O. R. DuARTE e S. POZZOLO,

Neoconstitucionalismo e positivismo jurídico. As faces da teoria do direito em tempos de interpretação moral da Constituição, São Paulo, Landy 2006; E. R. MOREIRA, Neoconstitucionalismo. A invasão da Constituição, São Paulo, Método, 2008."111

Também no tocante às relações entre a obra de Figueroa e a doutrina jurídica nacional, veja-se a "disputa em família" presente no livro de Thomas da Rosa Bustamante ${ }^{112}$ Teoria do direito e decisão racional: temas da teoria da argumentação jurídica. Este debate em alto nível - quiçá o único na literatura pátria jusfilosófica envolvendo um autor europeu e um brasileiro - está presente na segunda parte do livro, intitulada "Um debate sobre o neoconstitucionalismo", com os textos do jusfilósofo e constitucionalista mineiro: "Póspositivismo: o argumento da injustiça além da 'Fórmula de Radbruch"”, "Em busca de uma filosofia do direito não-positivista: revisando o debate com o professor Alfonso García Figueroa" e o texto de Figueroa: "Réplica al profesor Thomas da Rosa Bustamante".

Anexo 2 - Éticas cognitivistas vs éticas não-cognitivistas

O cerne do debate entre neoconstitucionalismo e positivismo jurídico, no âmbito filosófico, está relacionado à problemática da diferença entre éticas cognitivistas e nãocognitivistas. A credibilidade de algumas propostas cognitivistas no cenário contermporâneo - o projeto rawlsiano e a ética do discurso - ensejam um novo quadro a partir do qual as questões jusfilosóficas passam a ser compreendidas. Esclarecendo esta questão, temos que a ética do discurso, projeto desenvolvido por Jürgen Habermas, Karl-Otto Apel, Albrecht Wellmer e Robert Alexy, assume uma posição dentro das éticas cognitivistas, ou seja, uma perspectiva de “(...) filosofia moral que considera possível fundamentar a norma ética em princípios

\footnotetext{
111 "Neoconstitucionalismo: dos (o tres) perros para um solo collar: Notas a propósito del constitucionalismo juspositivista de Luigi Ferrajoli". In: DOXA - Cuadernos de Filosofia del Derecho, 34, 2011, pp. 123 e 124.

${ }^{112}$ BUSTAMANTE, Thomas da Rosa. Teoria do direito e decisão racional: temas de teoria da argumentação jurídica. Op. cit.
} 


\section{Quaestio Iuris}

gerais e abstratos, de caráter secular, e que em tese não postula qualquer diferença categorial entre o conhecimento dos fatos do mundo e os do mundo moral". ${ }^{113}$

Admitindo os juízos morais como assertivas passíveis de serem consideradas verdadeiras ou falsas, a perspectiva da ética do discurso concentra seu escopo de análise nas questões que tratam da 'justeza' das normas reguladoras da vida social aspiradoras à legitimidade. Não se encontram privilegiadas, dentro desta démarche, as questões atinentes à vida boa ou ao bem comum, já que "as éticas cognitivas eliminam os problemas do bem viver e concentram-se nos aspectos rigorosamente deônticos, generalizáveis, de tal modo que do bom resta apenas o justo". ${ }^{114}$

Como explica Luis Alberto Peluso ${ }^{115}$ : "Segundo o cognitivismo, os juízos morais são asserções e, portanto, passíveis de ser considerados verdadeiros ou falsos. O cognitivismo se apresenta em duas versões: naturalismo e intuicionismo. Segundo a variante naturalista, os predicados de caráter ético admitem redução a predicados de caráter não-ético. Assim, 'bem’ significaria o mesmo que 'útil' (utilitarismo) ou 'capaz de gerar prazer' (hedonismo). Enunciados morais podem ser derivados a partir de enunciados verdadeiros acerca do homem ou do mundo. Consequentemente, a investigação moral se torna dependente das ciências empíricas ou factuais. Em contrapartida, o intuicionismo (G.E. Moore, D. Ross, H.A. Prichard, A.C. Ewing) sustenta que os valores morais fundamentais são evidentes. Destarte, os juízos morais podem ser considerados verdadeiros, sem que para tal precisemos recorrer a qualquer instância empírica.

Ao contrário das concepções cognitivas, as doutrinas não-cognitivas sustentam que a esfera moral não é suscetível de ser apreendida por qualquer ato de cognição, os enunciados morais são insuscetíveis de receber um valor de verdade; não são passíveis de teste com base na observação ou no experimento. Segundo o emotivismo - variante do não-cognitivismo os enunciados morais têm a função de dar expressão a nossos sentimentos (A.J. Ayer) ou atitudes (Ch. L. Stevenson), bem como influenciar outros. Stevenson ressalta a função evocadora, dado que enunciados morais tendem a evocar em outros sujeitos determinadas emoções ou a produzir neles o efeito emocional."

Bibliografia

AARNIO, Aulis. Derecho, racionalidad y comunicación social: ensayos sobre filosofía del derecho. Ciudad del Mexico, Distribuciones Fontamara S.A., 2000.

; VALDÉS, Ernesto Garzón; UUSITALO, Jyrki. “Introducción”, In: La normatividad del Derecho. Barcelona, Editorial Gedisa, 1997.

\footnotetext{
${ }^{113}$ ROUANET, Sérgio Paulo. "Ética iluminista e ética discursiva". In: Habermas 60 Anos. Revista Tempo Brasileiro. Rio de Janeiro, Tempo Brasileiro, n 98, jul-set 1989, p. 19.

${ }^{114}$ HABERMAS, Jürgen. "Filosofia como Guardador de Lugar e Intérprete”. In: Consciência moral e agir comunicativo. Rio de Janeiro, Tempo Brasileiro, 1989, p.32.

${ }^{115}$ PELUSO, Luis Alberto. "Subsídios para uma interpretação do paradigma racionalista crítico de análise social”. In: CARVALHO, Maria Cecília M. de. (org.) Paradigmas filosóficos da atualidade. Campinas, Papirus, 1989, p. 117.
} 
GASCÓN, Marina Abellán; FIGUEROA, Alfonso García. La argumentación en el Derecho. Lima, palestra Editores, 2005;

ALEXY, Robert. Constitucionalismo discursivo. Porto Alegre, Livraria do Advogado, 2008. . El concepto y la natureza del Derecho. Madrid, Marcial Pons, 2008.

Gedisa, 1994. . El concepto y la validez del Derecho y otros ensayos. Barcelona, . “Aleksander Peczenik (1937-2005). In: Cuadernos de filosofía del Derecho, 29. Doxa, 2006.

2005. . La institucionalización de la justicia. Granada, Editorial Comares, . "Entrevista com o prof. Robert Alexy" In: Revista trimestral de direito civil - v. 16 (outubro/dezembro 2003). Rio de Janeiro, Padma, 2000.

. "Colisão e ponderação como problema fundamental da dogmática dos direitos fundamentais". Palestra proferida na Fundação Casa de Rui Barbosa, Rio de Janeiro, em 10.12.1998 (mimeo). vol. 3, n. 2 (julho 1989).

. "On Necessary Relations Between Law and Morality". In. Ratio Iuris,

ARANGO, Rodolfo. ¿Hay respuestas correctas en el derecho?. Santafé de Bogotá, Siglo del Hombre Editores, 1999.

ARISTÓSTELES. Tópicos (100 a.), Livro I. In. The Works of Aristotle. Volume 1, Chicago, The University of Chicago, Great books of the Western World, 1971.

ARIZA, Santiago Sastre. Ciência juridical positivista y neoconstitucionalismo. Madrid, McGraw Hill, 1999.

CARBONELL, "La ciência juridica ante el neoconstitucionalismo". In:

Miguel (org.). Neoconstitucinalismo (s). Madrid, Editorial Trotta, 2003.

ATIENZA, Manuel. "Entrevista a Robert Alexy”. In: Doxa - Cuadernos de Filosofia del Derecho n. 24, 2001.

$\overline{\text { Derecho, } \mathrm{n}^{\circ} \text { 29, } 2006 .}$

. "Entrevista a Neil MacCormick" In: Doxa. Cuadernos de filosofia del

El Derecho como argumentación. Concepciones de la argumentación.

Barcelona, Editorial Ariel, 2006. 
. "Es el positivismo jurídico uma teoria aceptable del derecho?" In.: MOREIRA, Eduardo Ribeiro; PUGLIESI, Marcio (coord.). 20 anos da Constituição brasileira. São Paulo, Saraiva, 2009.

. Trás la justicia.una introducción al Derecho y al razonamiento jurídico. Barcelona, Editorial Ariel, 1995

As razões do direito. Teorias da argumentação jurídica. Perelman, Toulmin, MacCormick, Alexy e outros. São Paulo, Landy Editora, 2000.

. "Argumentación jurídica". In: VALDÉS, Ernesto Garzón; LAPORTA, Francisco J. (org.). El derecho y la justicia. Madrid, Trotta, 2000.

"Is Legal Positivism a Sustainable Legal Theory?". In: GIZBERTSTUDNICKI, Tomasz; STELMACH, Jerzy. (Ed.). Law and legal cultures in the $21^{\text {st }}$ century: diversity and unity. Plenary Lectures. Warszawa, Oficyna, 2007.

1999.

. "El Derecho como argumentación". In: Isegoría. Madrid, Anábasis,

e MANERO, Juan Ruiz. Las piezas del Derecho. Teoria de los enunciados jurídicos. Barcelona, Editorial Ariel, 1996.

BAYNES, Keneth. "Deliberative Democracy and the Limits of Liberalism". In: VON SCHOMBERG, René e BAYNES, Keneth (ed.). Discourse and Democracy - Essays on Habermas's Between Facts end Norms. New York, State University of New York, 2002.

BARCELLOS, de Ana Paula. "Neoconstitucionalismo, direitos fundamentais e controle das políticas públicas". In. SARMENTO, Daniel e GALDINO, Flávio (orgs.). Direitos fundamentais: estudos em homenagem ao professor Ricardo Lobo Torres. Rio de Janeiro, Renovar, 2006.

BARRETTO, Vicente de Paulo (coord.). Dicionário de filosofia do direito. Rio de Janeiro, Editora Renovar; São Leopoldo, Editora Unisinos, 2006.

BARROSO, Luís Roberto. Curso de direito constitucional contemporâneo: Os conceitos fundamentais e a construção do novo modelo. São Paulo, Saraiva, 2010.

México, UNAM-IIJ, 2008.

El neoconstitucionalismo y la constitucionalización del Derecho, - "Neoconstitucionalismo e constitucionalização do direito. O triunfo tardio do direito constitucional no Brasil". In: Revista da EMERJ. Rio de Janeiro, EMERJ, v. 9, n. 33., 2006.

São Paulo, 15 de fevereiro de 2004.

. "O controle externo é favorável ao judiciário". In: Opinião. Folha de 
e BARCELLOS, Ana Paula. "A nova interpretação constitucional: ponderação, argumentação e papel dos princípios". In: LEITE, George Salomão (org.) Dos princípios constitucionais. Considerações em torno das normas principiológicas da Constituição. São Paulo, Malheiros, 2003.

"Fundamentos teóricos e filosóficos do novo direito constitucional brasileiro (Pós-modernidade, teoria crítica e pós-positivismo)". In: Revista Diálogo jurídico. Salvador, CAJ - Centro de Atualização Jurídica, v. I, nº 06, setembro, 2001.

BARZOTTO, Luis Fernando. O positivismo jurídico contemporâneo: Uma introdução a Kelsen, Ross e Hart. São Leopoldo, UNISINOS, 1999.

BITTAR, Eduardo C. B. (coord.). Educação e metodologia para os direitos humanos. São Paulo, Quartier Latin, 2008.

BRETON, Philippe e GAUTHIER, Gilles. Histoire des théories de l'argumentation. Paris, Éditions La Découverte, 2000.

BRUNET, Pierre. "Le droit est-il obligatoire? La response positiviste à traver une analyse critique du Neoconstitucionalisme". In: Le droit de résistance à lópression. Actes du colloque de Dijon (decembre 2002) D. Gros et O. Camu (dir.). Paris, Seuil, Le genre humain, 2005.

BUNCHAFT. Maria Eugenia. O patriotismo constitucional na perspectiva de Jürgen Habermas: A reconstrução da ideia de nação na filosofia política contemporânea. Rio de Janeiro, Lumen Juris, 2010.

BUSTAMANTE, Thomas da Rosa. Teoria do direito e decisão racional. Temas de teoria da argumentação jurídica. Rio de Janeiro, Renovar, 2008.

. "Comment on Petroski - On MacCormick's Post-Positivism". In: German Law Journal, vol. 12, nº 2, 2011.

Argumentação contra legem. A teoria do discurso e a justificação jurídica nos casos mais difíceis. Rio de Janeiro, Renovar, 2005.

e MAIA, Antonio Cavalcanti. “Argumentação jurídica”. In: BARRETO, Vicente de Paulo (org.). Dicionário de filosofia do direito. Rio de Janeiro/ São Leopoldo, Renovar/Editora Unisinos, 2006.

CALSAMIGLIA, Albert. "Ciência jurídica”. In: VALDÉS, Ernensto Garzón; LAPORTA, Francisco J. (org.). El Derecho y la justicia. Madrid, Editorial Trotta/Consejo superior de investigaciones científicas, 2000.

I, 1998.

.Pospositivismo". In: Doxa - Cuadernos de filosofia del Derecho, n. 21- 
. "Ensayo sobre Dworkin". In: DWORKIN, Ronald. Los derechos en serio, Barcelona, Ariel, 1997.

. "For Kelsen”. In: Ratio Juris, vol. 13, n. 2, junho 2000.

. “¿ Deve ser la moral el único critério para legislar?”, In: Doxa Cuadernos de filosofia del Derecho, n. 13, 1993.

CAMBI, Eduardo. Neoconstitucionalismo e neoprocessualismo: direitos fundamentais, políticas públicas e protagonismo judiciário. São Paulo, Editora Revista dos Tribunais, 2009.

. "Neoconstitucionalismo e neoprocessualismo". In: Revista do programa de pós-graduação em direito da Universidade Federal da Bahia. Salvador, Fundação Faculdade de Direito da Bahia Editora, 2008.

CANOTILHO, José Joaquim Gomes. "Civilização do direito constitucional ou constitucionalização do direito civil? - a eficácia dos direitos fundamentais na ordem jurídico-civil no contexto do direito pós-moderno". In: GRAU, Eros Roberto e GUERRA FILHO, Willis Santiago (org.). Direito Constitucional. Estudos em homenagem a Paulo Bonavides. São Paulo, Malheiros Editores, 2001.

CARBONELL, Miguel. e JARAMILLO, Leonardo García. El canon neoconstitucional. Madrid, Editorial Trotta, S.A., 2010.

. "Prólogo". In: BARROSO, Luís Roberto. El neoconstitucionalismo y la constitucionalización del derecho. Cidade do México, Universidad Nacional Autónoma de México, 2008.

. Teoria del neoconstitucionalismo. Ensayos escogidos. Madrid, Editorial Trotta e Instituto de Investigaciones Jurídicas - UNAM, 2007.

Neoconstitucionalismo(s). Madrid, Editorial Trotta, 2003.

CARRILHO, Manuel Maria. O que é filosofia. Lisboa, Difusão Cultural, 1994 Rhétoriques de la Modernité. Paris, PUF, 1992.

CATTONI, Marcelo. Poder constituinte e patriotismo constitucional. Belo Horizonte, Mandamentos, 2006.

CLÈVE, Clèverson Merlin. Estado constitucional, neoconstitucionalismo e tributação. MIMEO, sem data.

COMANDUCCI, Paolo. "Formas de (neo)constitucionalismo: um análisis metateórico". In: Isonomia, n. 16, 2002. 
; AHUMADA, Maria Ángeles; LAGIER, Daniel González. Positivismo jurídico y neoconstitucionalismo. Madrid, Fundación Coloquio Jurídico Europeo, 2009.

CONLEY, Thomas M. Rhetoric in the European Tradition. Chicago, The University of Chicago Press, 1990

DANTAS, David D. Interpretação constitucional no pós-positivismo. São Paulo, Madras, 2004.

DIAS, Ronaldo Bretãs de Cravalho. "A fundamentação das decisões jurisdicionais no Estado Democrático de Direito”. In: Processo e Constituição - estudos em homenagem ao professor Barbosa Moreira. São Paulo, Revista dos tribunais, 2006.

DÍAZ, Elias. "Filosofia del derecho: legalidad-legitimidad". In: MUGUERZA, Javier e CEREZO, Pedro (ed.). La filosofia hoy. Barcelona, Editorial Crítica, 2000.

DIMOULIS, Dimitri e DUARTE, Écio Oto. Teoria do direito neoconstitucional. Superação ou reconstrução do positivismo jurídico? São Paulo, Editora Método, 2008.

University Press, 1978.

. “A Reply to Critics”. In. Taking Rights Seriously. Cambridge, Harvard

DINIZ, Antonio Carlos de Almeida. Teoria da legitimidade do direito e do Estado: uma abordagem moderna e pós-moderna. São Paulo, Landy Editora, 2006.

DIREITO, Carlos Alberto Menezes; TRINDADE, Antônio Augusto Cançado; PEREIRA, Antônio Celso Alves (coord.). Novas perspectivas do direito internacional contemporâneo. Rio de Janeiro, Renovar, 2008.

DREIER, Ralf. Derechos y justicia. Bogotá, Temis, 1994.

DWORKIN, Ronald. "Is Law a System of Rules?" In: The Philosophy of Law. Oxford, Oxford University Press, 1986.

FARALLI, Carla. La filosofía del Derecho contemporánea. Los temas y desafíos. Bogotá, Universidad Externado de Colombia, 2007.

FIGUEROA, Alfonso García. "A motivação. Conceitos fundamentais”. In: MOREIRA, Eduardo Ribeiro (org.). Argumentação e o Estado Constitucional. São Paulo, Ícone, 2012.

"Neoconstitucionalismo: dos (o tres) perros para un solo collar: Notas a propósito del constitucionalismo juspositivista de Luigi Ferrajoli”. In: Doxa - Cuadernos de Filosofia del Derecho, 34, 2011.

. "La revancha neoconstitucionalista de Grecia contra Roma: notas sobre la inviabilidad de las reglas en el Estado constitucional" In: Foro jurídico: Revista de Derecho, no 10. Lima, Foro Académico Asociación Civil, abril de 2010. 
Criaturas de la moralidad: una aproximación neoconstitucionalista al Derecho a través de los derechos. Madrid, Editoral Trotta, 2009.

. "Prólogo" In: VALE, André Rufino do. Estrutura das normas de direitos fundamentais: repensando a distinção entre regras, princípios e valores, Editora Saraiva, São Paulo, 2009.

. "Princípios e direitos fundamentais" In: SOUZA NETO, Cláudio Pereira e SARMENTO, Daniel. A constitucionalização do direito: fundamentos teóricos e aplicações específicas. Rio de Janeiro, Lumen Juris, 2007.

y Constitucionale, 2006.

(coord.) Racionalidad y Derecho. Madrid, Centro de Estúdios Políticos

. "La incidencia de la derrotabiliad de los princípios iusfundamentales sobre el concepto de Derecho". In: Diritto \& questionni pubbliche. n.3, 2003.

"La teoria del derecho en tiempos de constitucionalismo". In: CARBONELL, Miguel (org.). Neoconstitucionlaismo(s). Madrid, Editorial Trotta, 2003.

Princípios y positivismo jurídico. El no positivismo principialista em las teorias de Ronald Dworkin y Robert Alexy. Madrid, Centro de Estúdios Políticos y Constitucionales, 1998.

"El no positivismo principialista en Il diritto mite de Gustavo Zagrebelsky". In: Anuario de filosofia del Derecho XIII. Boletín Oficial del Estado, 1996.

FOLSCHEID, Dominique e WUNENBURGER, Jean-Jaques. Metodologia filosófica. São Paulo, Martins Fontes, 1997.

FREITAS, Juarez. "O intérprete e o poder de dar vida à Constituição: preceitos de exegese constitucional". In: GRAU, Eros Roberto e GUERRA FILHO, Willis Santiago (org.). Direito constitucional. Estudos em homenagem a Paulo Bonavides. São Paulo, Malheiros Editores, 2001.

FRYDMAN, Benoit e HAARSCHER, Guy. Philosophie du droit. Paris, Dalloz, 2002.

GIANFORMAGGIO, Letizia. "Prefácio". In: Qu'est - ce que le positivisme juridique?. Traduit par Colette Clavreul. Paris, Bruylant L.G.D.J, 1996.

GRANZINOLI, Cassio Murilo Monteiro. Interpretação e argumentação jurídica: uma contribuição para a fundamentação e justificação das decisões judiciais. Rio de Janeiro, Forense, 2009. 
GUASTINI, Ricardo. “La 'constitucionalizacion' del ordenamiento jurídico: el caso italiano”. In. CARBONELL, Miguel (org.). Neoconstitucionlaismo(s). Madrid, Editorial Trotta, 2003.

GUERRA FILHO, Willis. Teoria processual da Constituição. São Paulo, Celso Bastos Editor, 2002.

HABERMAS, Jürgen. Verdad y justificacion. Ensayos filosóficos. Madrid, Editorial Trotta, 2002.

- Fragmentos filosófico-teológicos: De la impression sensible a la expresión simbólica. Madrid, Editorial Trotta, 1999.

. Between Facts and Norms: Contributions to a Discourse Theory of Law and Democracy. Cambridge, The MIT Press, 1996.

. The Theory of Communicative Action. Vol I. Reason and the Rationalization of Society. Boston, Beacon Press, 1984.

. "Teorias de la verdad". In: Teoría de la acción comunicativa:

complementos y estudios prévios. Madrid, Cátedra, 1994.

HART, Herbert. O conceito de direito. Lisboa, Calouste Gulbenkian, 1986

LA TORRE, Massimo. "Theories of Legal Argumentation and Concepts of Law. A Approximation”. In: Ratio Juris. Vol. 15. n. 4. Oxford, Blackweel Publishers, 2002.

LENOBLE, Jacques e BERTEN, André (ed.) Dire la norme. Droit, politique et énonciation. Paris, LGDJ, 1990.

LIMA, Marcelo. "Notas sobre o dever constitucional de fundamentar as decisões judiciais". In: Processo e Constituição - estudos em homenagem ao professor Barbosa Moreira. São Paulo, Revista dos tribunais, 2006.

LLORENTE, Francisco Rubio. "Presentación". In: ALEXY, Robert. Epílogo a aa teoria de los Derechos fundamentales. Madrid, Fundacion Beneficentia et Peritia Iuris, 2004.

LOPES, Antonio Herculano e CALABRE, Lia (org.). Diversidade cultural brasileira. Rio de Janeiro, Edições Casa de Rui Barbosa, 2005

MacCORMICK, Neil. H.L.A. Hart. Stanford, Stanford University Press, 1981. Argumentação jurídica e teoria do direito. São Paulo, Martins Fontes, 2006. . "Contemporary Legal Philosophy: the Rediscovery of Practical Reason" In: Journal of Law \& Society, volume 10, número 1, verão de 1983. 
MAIA, Antonio Cavalcanti. "Posfácio: Notas sobre motivação das decisões judiciais" In: GRANZINOLI, Cássio Murilo Monteiro. Interpretação e Argumentação Jurídica: Uma contribuição para a fundamentação e justificação das decisões judiciais. Rio de Janeiro, Forense, 2009

. "Habermas/Alexy e o discurso prático". In: PINZANI, Alessandro; LIMA, Clóvis Montenegro de; DUTRA, Delamar V. (Coord.) O pensamento vivo de Habermas: uma visão interdisciplinar. Florianópolis, NEFIPO, 2009.

"Nos vinte anos da Carta Cidadã: do pós-positivismo ao neoconstitucionalismo". In: SOUZA NETO, Cláudio Pereira de; SARMENTO, Daniel; BINENBOJM, Gustavo (coord.). Vinte anos da Constituição Federal de 1988. Rio de Janeiro, Lumen Juris, 2009.

Jürgen Habermas: filósofo do direito. Rio de Janeiro, Renovar, 2008.

"Acerca dos direitos humanos e o diálogo intercultural" In: BITTAR,

Eduardo C. B. (coord.) Educação e metodologia para os direitos humanos. São Paulo, Quartier Latin, 2008.

. "Patriotismo constitucional e patriotismo republicano". In: DIREITO, Carlos Alberto Menezes; TRINDADE, Antonio Augusto Cançado; PEREIRA, Antonio Celso Alves (orgs.). Novas perspectivas do direito internacional contemporâneo. Estudos em homenagem ao professor Celso de D. Albuquerque Mello. Rio de Janeiro, Renovar, 2008.

.Prefácio: O direito constitucional do limiar do século XXI: princípios jurídicos e pós-positivismo”, In: MORAES, Guilherme Peña. Readequação constitucional do Estado moderno: transformações do conceito de Estado no direito constitucional do limiar do século XXI. Rio de Janeiro, Editora Lumen Juris, 2006.

. "Prefácio. O direito entre o moderno e o pós-moderno: é possível escapar da antinomia Habermas/Luhmann?" In: DINIZ, Antonio Carlos de Almeida. Teoria da legitimidade do direito e do Estado: uma abordagem moderna e pósmoderna. São Paulo, Landy Editora, 2006.

e BUSTAMANTE, Thomas da Rosa."Argumentação jurídica". In: BARRETO, Vicente de Paulo (org.). Dicionário de filosofia do direito. Rio de Janeiro/ São Leopoldo, Renovar/Editora Unisinos, 2006.

“Argumentação" In: BARRETO, Vicente de Paulo (org.). Dicionário de filosofia do direito. Rio de Janeiro/ São Leopoldo, Renovar/Editora Unisinos, 2006.

"As transformações dos sistemas jurídicos contemporâneos: apontamentos acerca do neoconstitucionalismo". In: Crítica - Revista de filosofia n ${ }^{\circ} 34$, volume 11. Londrina, Universidade Estadual de Londrina, 2006. 
e DINIZ, Antonio Carlos. "Pós-Positivismo" In: BARRETO, Vicente de Paulo (org.). Dicionário de filosofia do direito. Rio de Janeiro/ São Leopoldo, Renovar/Editora Unisinos, 2006.

"As transformações dos sistemas jurídicos contemporâneos: apontamentos acerca do neoconstitucionalismo". In: Crítica - Revista de filosofia ${ }^{\circ}$ 34, volume 11. Londrina, Universidade Estadual de Londrina, 2006.

. "Posfácio: Diversidade cultural, identidade nacional brasileira e patriotismo constitucional". In: LOPES, Antonio Herculano e CALABRE, Lia (orgs.). Diversidade cultural brasileira. Rio de Janeiro, Edições Casa de Rui Barbosa, 2005.

"Considerações introdutórias. Textura aberta da linguagem e interpretação jurídica: Considerações acerca da tese da autoctonia do discurso jusfilosófico". In: STRUCHINER, Noel. Direito e linguagem: Uma análise da textura aberta da linguagem e sua aplicação ao direito. Rio de Janeiro, Renovar, 2002.

e ARAUJO, Nadia de. "Reflexões sobre pesquisa na área jurídica propostas da disciplina de Metodologia" In: RTDC - Revista Trimestral de Direito Civil, Ano 3, vol. 10. Rio de Janeiro, Padma, 2002.

. "Posfácio: a importância da dimensão argumentativa à compreensão da práxis contemporânea”. In: CAMARGO, Margarida Maria Lacombe. Hermenêutica e argumentação: uma contribuição ao estudo do direito. Rio de Janeiro, Renovar, 2001.

e SOUZA NETO, Cláudio Pereira de. "Os princípios de direito e as perspectivas de Perelman, Dworkin e Alexy” In: PEIXINHO, Manoel Messias et al (org.). Os princípios da Constituição de 1988. Rio de Janeiro, Lumen Juris, 2001.

. "Notas sobre direito, argumentação e democracia". In: CAMARGO, Margarida Maria Lacombe (org.). 1988 - 1998: Uma década de

Constituição. Rio de Janeiro, Renovar, 1999.

MARINONI, Luiz Guilherme. Curso de processo civil, volume I: teoria geral do processo. São Paulo, Editora Revista dos tribunais, 2006.

. "Da teoria da relação jurídica processual ao processo civil do estado constitucional”. In: SOUZA NETO, Cláudio Pereira e SARMENTO, Daniel (coords.). Rio de Janeiro, Lumen Juris, 2007

MASSANERO, Maria de los Ángeles. De la argumentación al derecho razonable. Un estúdio sobre Chaïm Perelman. Navarra, Eunsa, 2001.

MAUS, Ingeborg. Judiciário como superego da sociedade: o papel da atividade jurisprudencial na sociedade órfã. In: Novos Estudos, CEBRAP, nº 58, nov. 2000. 
MAZZARESE, Tecla. "Appunti del corso di filosofia del diritto", 2000/2001 apud POZZOLO, Susana. "Um constitucionalismo ambíguo". In: CARBONELL, Miguel (org.). Neoconstitucionalismo (s). Madrid, Editorial Trotta, 2003.

MESA, Gloria Patrícia Lopera. La aplicación del Derecho en los sistemas jurídicos constitucionalizados. Medelin, março de 2004 (mimeo).

MILOVIC, Miroslav. Comunidade da diferença. Rio de Janeiro, Relume Dumará; Ijuí, Unijuí, 2004.

MORAES, Guilherme Peña de. Readequação constitucional do Estado moderno: transformações do conceito de Estado no direito constitucional do limiar do século XXI. Rio de Janeiro, Lumen Juris, 2006.

MOREIRA NETO, Diogo de Figueredo. "Direitos humanos, legitimidade e constitucionalismo". In: SARMENTO, Daniel e GALDINO, Flávio (orgs.). Direitos fundamentais: estudos em homenagem ao professor Ricardo Lobo Torres. Rio de Janeiro, Renovar, 2006.

MOREIRA, Eduardo Ribeiro. Neoconstitucionalismo: a invasão da Constituição. São Paulo, Editora Método, 2008.

Saraiva, 2009. e PUGLIESI, Marcio. 20 anos da constituição brasileira. São Paulo,

MOREIRA, José Carlos Barbosa. "Raisonnements judiciaires dans les Cours D’appel”. In: Temas de direito processual, Rio de Janeiro, Editora Saraiva, 1994

MORESO, José Juan. "Comanducci sobre neoconstitucionalismo". In. Isonomia, n. 19, 2003.

MÜLLER, Jan-Werner. Constitutional Patriotism. Princeton, Princeton University Press, 2007.

NIGRO, Rachel. “A virada linguístico-pragmática e o pós-positivismo”. In: Direito, Estado e sociedade. Rio de Janeiro, Pontifícia Universidade Católica - Departamento de Direito, 2009.

NINO, Carlos Santiago. La validez del Derecho. Buenos Aires, Editorial Astrea, 2003.

OLÉRON, Pierre. L’argumentation. Paris, Presses Universitaires de France, 1983.

OLIVEIRA JÚNIOR, José Alcebíades de. "Casos difíceis no pós-positivismo". In. BOUCAULT, Carlos E. de Abreu; RODRIGUEZ, José Rodrigo. (org.). Hermenêutica plural. São Paulo, Martins Fontes, 2002.

PECZENIK, Aleksander. Derecho y razón. México, Fontamara, 2000. 
PEIXINHO, Manoel Messias; GUERRA, Isabella Franco (orgs). Os princípios da Constituição de 1988. Rio de Janeiro, Editora Lúmen Júris, 2001.

PERELMAN, Chaïm e OLBRECHTS-TYTECA, L. Traité de l'argumentation. La nouvelle rhétorique. Bruxelas, Editions de l'Université de Bruxelles, 1983.

PERELMAN, Chaïm. Ética e Direito, São Paulo, Martins Fontes, 1996 Logique juridique. Nouvelle rhétorique. Paris, Dalloz, 1979. La lógica jurídica y la nueva retórica. Madrid, Civitas, 1979.

PICAVET, Emmanuel. Kelsen et Hart. La norme et la conduite. Paris, Presses Universitaires de France, 2000.

POZZOLO, Suzanna e DUARTE, Écio Oto Ramos. Neoconstitucionalismo e positivismo jurídico: as faces da teoria do direito em tempos de interpretação moral da Constituição . São Paulo, Landy Editora, 2006.

PRIETO SANCHÍS, Luis. Jueces y justicia em tiempos de constitucionalismo - entrevista al profesor Luis Prieto Sanchís realizada por Pedro P. Grández Castro (mimeo). Toledo, 2005.

Trotta, 2000. Justicia constitucional e derechos fundamentales. Madrid, Editorial Constitucionalismo y positivismo. México, Distribuciones Fontamara, 1999.

PULIDO, C. Bernal, El neoconstitucionalismo y la normatividad del derecho, Bogotá, Universidad Externato de Colombia, 2009.

CEC, 2007. El principio de proporcionalidad y los derechos fundamentales, Madrid, .Refutación y defensa del neconstitucionalismo" In: CARBONELL, Miguel (Ed.) Teoría del neoconstitucionalismo. Madrid, Editorial Trotta, 2007

QUARESMA, Regina; OLIVEIRA, Maria Lúcia; DE OLIVEIRA, Farlei Martins. (coords). Neoconstitucionalismo. Rio de Janeiro, Forense, 2009.

QUEIROZ, Cristina M. M. Direitos fundamentais (teoria geral). Coimbra, Coimbra Editora, 2002.

REGLA, Josep Aguiló. “Del ‘imperio de la ley’ al ‘estado constitucional'. Dos paradigmas jurídicos en pocas palabras”. In.: (coord.) MOREIRA, Eduardo Ribeiro; PUGLIESI, Marcio. 20 anos da Constituição Brasileira. São Paulo, Saraiva, 2009 
SARMENTO, Daniel (coord.). Filosofia e teoria constitucional contemporânea. Rio de Janeiro, Editora Lumen Juris, 2009.

e SOUZA NETO, Cláudio Pereira (coord.). A constitucionalização do

direito: fundamentos teóricos e aplicações específicas. Rio de Janeiro, Lumen Juris, 2007.

e GALDINO, Flavio (org). Direitos fundamentais: estudos em homenagem ao professor Ricardo Lobo Torres, Rio de Janeiro, Renovar, 2006.

SCARPELLI, Uberto. Qu'est - ce que le positivisme juridique?.Paris, Bruylant L.G.D.J, 1996.

SCHWARTZ, Germano (org.) Jurisdição das esferas sociais e fragmentação do direito na sociedade contemporânea. Porto Alegre, Livraria do Advogado Editora Ltda., 2012.

SCRUTON, Roger. Thinkers of New Left. Londres, Longman, 1985.

SERNA, Pedro. "Prefácio". In: CRUZ, Luis M. La Constitución como orden de valores, problemas jurídicos y políticos: un estudio sobre los orígenes del neoconstitucionalismo. Granada, Editoral Comares, 2005.

SHAND, John. Arguing Well. Londres, Routledge, 2000.

SIEBENEICHLER, Flávio Beno. "Uma Filosofia do direito procedimental". In. FREITAG, Bárbara (org.). Jürgen Habermas: 70 anos. Rio de Janeiro, Tempo

Brasileiro, 1999.

SIMIONI, Rafael. "O que a decisão jurídica observa? Contribuições da teoria dos sistemas de Niklas Luhmann às teorias pós-positivistas da decisão jurídica”. In: SCHWARTZ, Germano (org.). Juridicização das esferas sociais e fragmentação do direito na sociedade contemporânea. Porto Alegre, Livraria do Advogado Editora, 2012.

SOPER, Philip. Una teoría del Derecho. Madrid, Centro de Estudios Constitucionales, 1993.

SOUZA NETO, Cláudio Pereira de. "A Teoria constitucional e seus lugares específicos: notas sobre o aporte reconstrutivo". In: Revista de direito do Estado, n. 1. Rio de Janeiro, Renovar, janeiro/março 2006.

Teoria constitucional e democracia deliberativa. Um estudo sobre o papel o direito na garantia das condições para a cooperação na deliberação democrática. Rio de Janeiro, Renovar, 2006.

; SARMENTO, Daniel; BINENBOJM, Gustavo. Vinte anos da Constituição Federal de 1988. Rio de Janeiro, Lumen Juris, 2009.

STAMATIS, Constantin M. Argumenter em droit. Une théorie critique de l'argumentation juridique. Paris, Éditions Publisud, 1995. 


\section{Quaestio Iuris}

STRECK, Lenio Luiz. "Os juizados especiais criminais à luz da jurisdição constitucional. A filtragem hermenêutica a partir da aplicação da técnica da nulidade parcial sem redução de texto". In: Revista da EMERJ, v.6, n.24, Rio de Janeiro, EMERJ, 2003.

. "A resposta hermenêutica à discricionariedade positivista em tempos de pós-positivismo". In: DIMOULIS, Dimitri e DUARTE, Écio Oto. Teoria do direito neoconstitucional. Superação ou reconstrução do positivismo jurídico? São Paulo, Editora Método, 2008.

. "A crise paradigmática do direito no contexto da resistência positivista ao (neo)constitucionalismo." In: NETO, Cláudio Pereira de Souza; SARMENTO, Daniel; BINENBOJM, Gustavo (coords). Vinte anos da Constituição Federal de 1988. Rio de Janeiro, Editora Lúmen Júris, 2009.

STRUCHINER, Noel. Direito e linguagem: Uma análise da textura aberta da linguagem e sua aplicação ao direito. Rio de Janeiro, Renovar, 2002.

. "Uma análise da noção de casos difíceis do direito em um contexto positivista". In: Direito, Estado e sociedade - Revista do Departamento de Direito da PUCRio. n. ${ }^{\circ}$ 17, ago/dez., 2000.

TARUFFO, Michele. La motovación de la sentencia civil. Madrid, Editorial Trotta/Tribunal Electoral del Poder Judicial de la Federación, 2011.

. "Il significato costituzionale dell'obligo di motivazione". In. GRINOVER, Ada Pelegrini; DINAMARCO, Cândido Rangel; WATANABE, Kazuo (coords.). Participação e processo. São Paulo, Editora Revista dos Tribunais, 1988.

TEUBNER, Gunther. O direito como sistema autopoiético. Lisboa, Fundação Calouste Gulbenkian, 1989.

TOMAS, Gil. "La diskursethik et la théorie de l'argumentation de Ch. Perelman deux conceptions différentes de la rationalité pratique". In. PERELMAN, Chaïm. Et la pensée contemporaine. Bruxelas, Bruylant, 1993.

TOULMIN, Stephen. Os usos do argumento. São Paulo, Martins Fontes, 2001.

VIEIRA, Oscar Vilhena. “A Constituição como reserva de justiça”. In: Lua Nova, São Paulo, 1997.

WALLUCHOV, Wilfrid. "Legal Positivism, Inclusive versus Exclusive” In: E. Craig (ed.), Routledge Encyclopedia of Philosophy. Londres, Routledge, 2008.

WINCH, Peter. A idéia de uma ciência social e sua relação com a filosofia. São Paulo, Companhia Editora Nacional, 1970 
Quaestio Iuris

vol.04, no-01. ISSN 1516-0351

ZAGREBELSKY, Gustavo. El Derecho dúctil. Ley, derechos y justicia. Madrid, Editorial Trotta, 1995. 